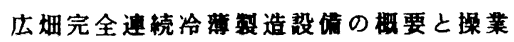

一一酸洗 〜䢖続烧鈍連続化一-

新日本製鐵（株）広畑製鐵所

古谷养川崎良樹 ○河波保雄

本社柳涾紀元旭岡達司

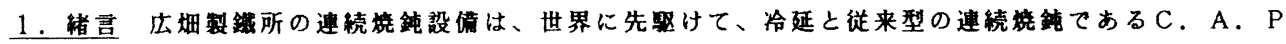
。L。との直結を果たした贽偏として、昭和 57 年 8 月に操業を開始した。この度、更に発展させて入 侧に酸洗設偖を配置することて、完全連続冷溥慗造設储（FＩＰＬと称す）として冷薄製造工程の連続 化の完成を見た。本設偳は昭和 61 年 11 月に稼俚を開始し現在順調に生産を行っている。本報告では 、主として酸洗設偝の概要とその特徽を紹介する。

\title{
2. 鈠借概要
}

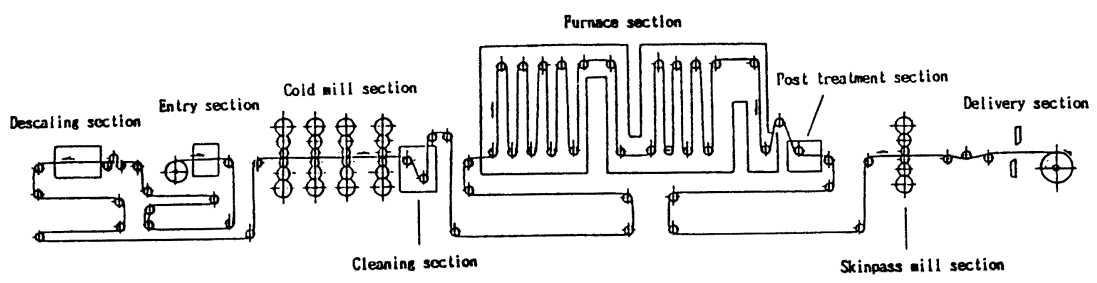

Fig. 1 Layout of FIPL

Fig. 1 に本設借の㭗成を、Table 1 にその主仕様を示す。棁スケー ル設偏は、埵デスケーリング材の高奻率脱スケール性を実現するため に最大伸率 $5 \%$ のテンションレベラーを配置し、その後に、テンショ ンレベラーで虽離されたスケールを研掃することにより塩酸原単位の 向上を目的としてブラシュニットを配置した。これにより、酸洗槽は

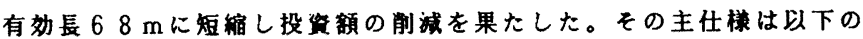
通り。

（1）テンションレベラー：最大伸率 $5 \%$ 、2 伸長ユニット ロール经 $80 \varnothing$

（2）ブラシュニット：砥入りナイロンブラシ 1 対

(3) 酸洗棈 : $17 \mathrm{~m} \times 4$ 棤

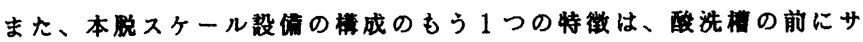

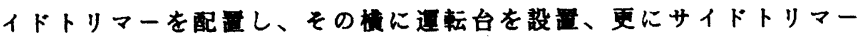
の下部直近に酸洗後の板表面钼策のための柊查台を配暴することて、 ライン通転・テンションレベラーロール組替・トリミング・格查の全 作萧の 1 人作萧を可能としたことててある。

3.操萧状況 全連結後の立上りは檑めて順周であり、Fig. 2 に示す ように4ケ月目には、全連結以前の生産量以上の成䋖を収めている。

(1) テンションレベラー伸び率は、Min. 3\%で探萧している。

（2）酸洗速度は、傕脱スケール材ても、Max. $200 \mathrm{mpm}$ ての通板 か可能てある。

（3）塩酸単位は、広㚼 3 P L に比し、約 $25 \%$ 向上した。
Table 1 Main Specification

\begin{tabular}{|c|c|}
\hline Item & Specification \\
\hline Capacity & $91000 \mathrm{~T} / \mathrm{M}$ \\
\hline Thicknes & $\begin{array}{ll}\text { Entry } & : 2.0 \sim 5.0 \\
\text { Delivery } & : 0.4 \sim 2.0\end{array}$ \\
\hline Width & $700 \sim 1650$ \\
\hline Speed & $\begin{array}{ll}\text { Entry } & : 300 \mathrm{mpm} \\
\text { Descale } & : 200 \\
\text { Mill } & : 600 \\
\text { Furnace } & : 450 \\
\text { Delivery } & : 750\end{array}$ \\
\hline
\end{tabular}

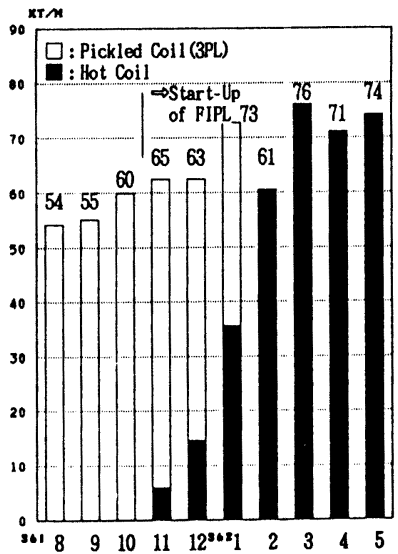

Fig. 2 Production Amount 
1. 緒言：冷延鋼板の表面は, その製造最終段階の調質圧延にわいて粗度調整が行なわれる。最近, 鋼 板の塗装後鮮映性は表面粗度と密接に関連しているととが明らかになり, 鋼板表面粗度を高度に管理す るととによって高鮮映性鋼板の製造が実現し, 実用化されている。ての際問題となるのは, 表面粗度の 測定技術である。従来, 粗度は, ランダム, 無方向性の山凸によって構成されているととを前提とし ており，その測定に際しては，鋼板の表面形状を任意の一方向に限って測定しているにすきない。し かし, レーザーダル技術の様に, 表面粗度に, 規則性, 周期性がある時には従来の一断面の表面形状を 測定する方法では，正確に鍮板表面の粗度を代表していない事，さらに，凹部，凸部の三次元的な拡が り，規則性が測定できない事が問題としてあった。本発表は，ての対策として導入した三次元粗度測定 装置を用いて行った種々の冷延鋼板の表面粗度測定例から得た知見を紹介する。 2. 測定方法：一般冷延鋼板の調質圧延において，通常のショットブラストダル加工お よびレーザーダル加エロールを用いて表面粗度を調整した鋼板を試料とし表面 粗度を測定した。三次元粗度測定は，接触式走査型粗度計を用いて行なった。 本測定装置に接続した粗度解析装置を用いて三次元粗度パラメー夕を算出した。

3. 実験結果： \#50ショットブラストダルおよびレーザーダル鋼板の表面 光顕観察結果および三次元粗度測定結果をFig. 1 亿示す。三次元粗度解析に よってはじめて凹部，凸部の形状，分布状態が測定可能となる。

レーザーダル技術による表面粗度の特徽は, 凹凸の規則性, 周期性にあるが， Fig. 2 に示すように, その測定は, 従来の三次元的な粗度測定では不可能で あり，逆に誤まった粗度測定結果になることがわかる。 三次元粗度測定によってはじめて測定可能とな った 粗度パラメータとしては, 中心面面積率, ( SSr) あるいは中心面粒度 ( SGr ) 等があるが, これらは, 平均粗度とともに, 鋼板表面の粗度プ ロファイルを特徴付ける重要なパラメーターである。

4. まとめ：冷延鋼板の表面粗度測定法におい て，レーザーダル技術のように規則性，周期性 のある表面粗度が付与可能となる場合, 従来の 表面粗度測定法のようにある一断面の表面形状 を測定しただけでは，正確に表面粗度の特徴を 評価できない。また，凹部，凸部の三次元的 な拡がりを評価する新しいパラメーターは，今 後の高度な表面粗度管理による新製品の開発に 有効である。
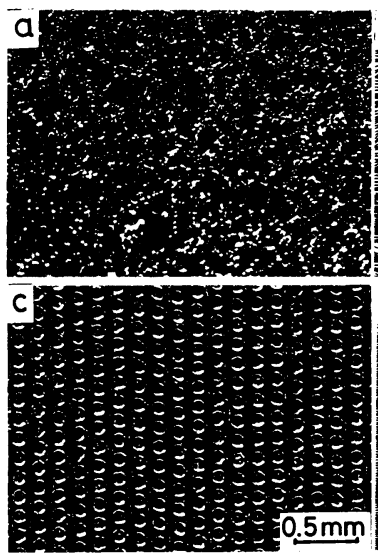

Optical micrograph

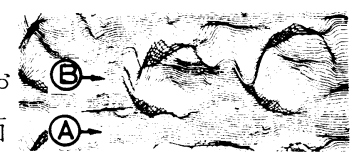

(a) 3-D roughness profile

(b) 2-D roughness profile at (A) line

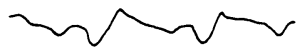

(c) 2-D roughness profile at (B) line

Fig.2 Typical roughness profiles of 1 aser textured steel sheets.

Fig. 1 Typical surface textures of laser-textured dull and shot-blasted dull steel sheets .

(a), (b) ; shot -blasted dull; (c) ,(d) , laser-textured dull. 
川崎製鉄(制) 鋼研究所 水島製鉄所 千葉製鉄所
今中 誠, ○小原隆史, 角山浩三 古川九州男

岸田 朗, 関谷 広

1. 緒言：冷延鋼板の表面粗度は通常ショットブラストダル法によって付与されるが, この方法では, 粗度ブファイルのコントロールは不可能である。しかし最近、レーザー技術を応用したスキンパスロ 一ルのダル目付け法が開発され, 粗度ブロファイルのコントロールが可能になった。その応用として 冷延﨨板の重要な表面特性である塗装後鮮映性の改善を試み，良好な結果を得たので報告する。

2 レーザータル法による鎆板表面粗度の特徴：レーザーダルはスキンパスロールの表面にパルスレー ザーによってマイクロクレーターを規則的に多数付加する加工法であり，てのロールを用いてスキンパ スを行なうととによって鋼板表面は, Fig1(a)の上段に示すような粗度プロファイルが転写される。 レーザーダル法の場合, このマイクロクレーターの径および, 間隔を制御するてとによって, 粗度プロ ファイルを変えるととができる。Fig 1 (b) に従来のショットブラスト法（；５０）による鋼板表面粗度を 示す。両者の比較から,レーザーダルによる表面粗度の特徵として, (1)平坦部面積率が多い。(2凹部, 凸部が規則的であり，その周期も制御可能である点が挙げられる。さらに、ショットブラスト法の場合, 粗度プロファイルにおける長波長成分（うねり）を見た場合，加工法の制約からうねりを小さくした りそのの波長をコントロールするととは出来ない。レーザーダルの場合には, 粗度プロファイルの凹凸 波長は, マイクロクレーターの径および間隔によって決まるため,コントロールが可能となる。

3. 鮮映性向上のメカニズム：従来鮮映性を向 上するには, 粗度を小さくすることが有効であ ると言われてきた。しかし本質的に塗装後の鮮 映性と相関があるのは, 粗度プロファイルの中 のうねりの成分であり,その抑制が可能なレー ザーダルは, 鮮映性向上に有効であるととがわ かった（Fig 1)。Fig 2 には平均粗さ(SRa)と 鮮映性 (DOI) の関係を示す。同一粗度で比較し

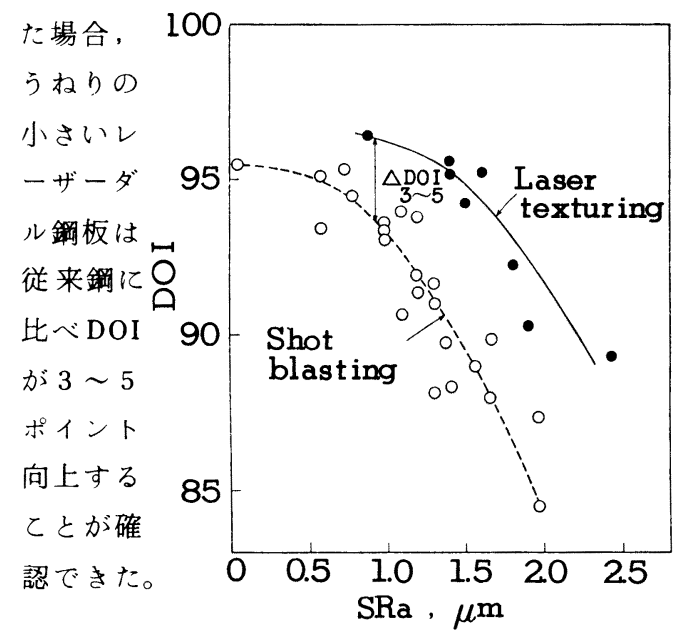

Fig. 2 Relationship between DOI and SRa of the 3 layercoated steel sheets.
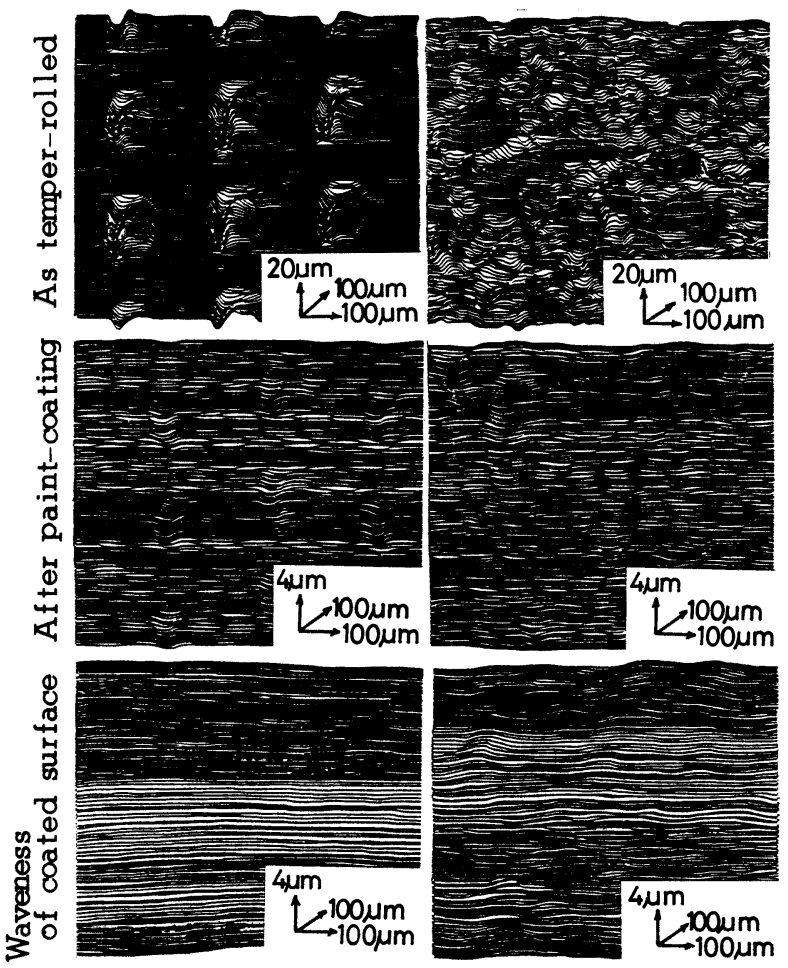

(a) Laser-textured dull (b) shot-blasted dull

Fig. 1 3-D roughness profiles of laser dull and shot blasting dull sheet surface. 
(304）新方式レベラを有するシャラインの開発

\begin{tabular}{|c|c|c|c|}
\hline 住友金属工莱附 & & & \multirow{2}{*}{ 所 } \\
\hline 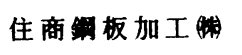 & 技 & & \\
\hline
\end{tabular}

1. 粕 言

需要家の平坦要求が益々麇しくなっており，最格工程のシャラインでの平坦满正能の向上が望まれて

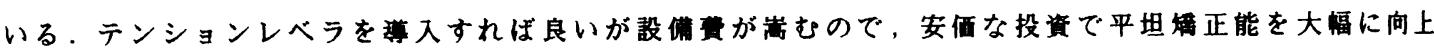
させた新しいシャラインの開発を行った。

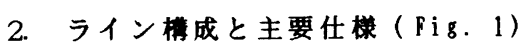
主レベラ入側に小径の非駆動レベラ を挋面し，ペイオフリール張カにレヘ ラ引抜力を重瞉して高張力曲げ引張り を可能とする．主レベラ出側にはタブ

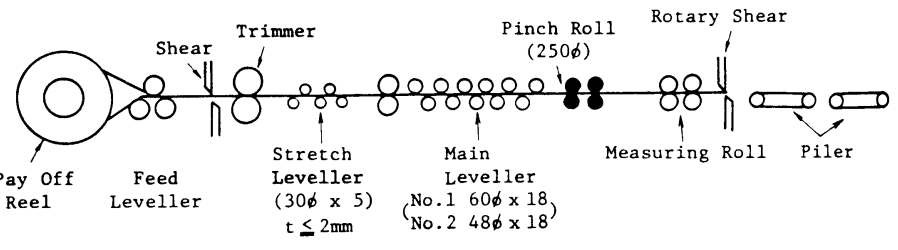
ルピンチロールを配宣して，主レベラ と併せてストリップを引抜さレベリン クし，塑性伸びを付与して平坦棈正す る。主レベラは 2 台配備されており， 板厚に心して短時间で交換可能な方式 となっている。また伸長レベラは非曼

\begin{tabular}{|l|c|l|l|}
\hline Material & Hot, Cold, Galvanized & Coil Neight & MaX. 30 (TON) \\
\hline Thickness & $0.3 \sim 3.2(\mathbf{m})$ & Line Speed & MaX. $100(\mathbf{m} / \mathbf{m i n})$ \\
\hline Midth & $500 \sim 1650(\mathbf{m})$ & Sheet Length & $250 \sim 3100(\mathbf{m})$ \\
\hline
\end{tabular}

Fig. 1 Layout of shear line and main specifications 娌故ロール交摸が容易で任意のクラウンロールが道用できる。 なお主レベラには従来のロールクラウン調整装正も装備されて いる．厚物のそり樰正と残留応力の低娍には主レベラの強力レ ベリングで対处するが，形状不良正には伸長レベラと主レベ ラでの張カレベリンクで対処する。

\section{3. 灀正奻果}

ペイオフリール張力を $900 \mathrm{~kg}$ 一定とし, 主レベラ氏下量を固 定して伸長レベラ压下吾を变化させた場合の再レベラ间張力， 伸ひ，急线度変化をPig. 2に示す，伸長レベラ圧下につれ，張 力，伸びが增大し，テンションレベラに匹敕する平坦度が碓保 できる、㯕械試值に愊方向分布を有する材料に対してはテー パロールの採用が有奻であった。Pig.3は厚物のリシャ後のそ り分布を示す. 強圧下レベリンクにより切断加工啳のそり発生 が防止でを，配等の平坦シビア用途にも充分道用できる。

4. 桔 言

主レヘララ前後に小径非駆動レベラとタフルピンチロールを眍 更した新方式レベラを有するシャラインを网発し，テンション レベラに匹敕する平坦度が得られることを磼訆した。

<奇考文戴>1）益居ら：S 61年塑加春講諭 311,315

2）武田ら：铁と，72(1985), S 351

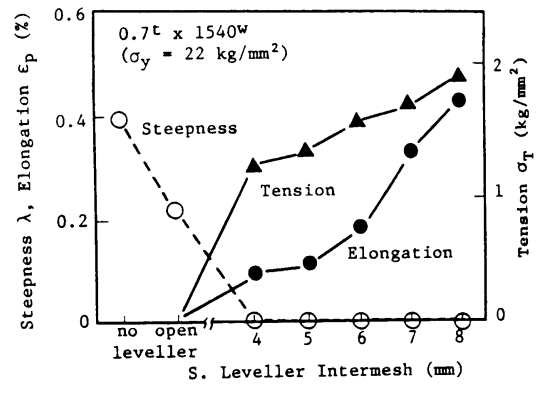

Fig. 2 Shape correction

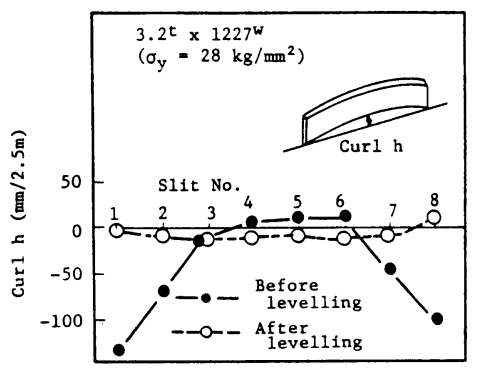

Fig. 3 Curl after slitting 


\section{（305）ウェルダー溶接スパッタ除去装置の開発}

日本鋼管福山製鉄所 小川定義 三世川慶一

加藤和佳 $\bigcirc$ 藤井達朗

\section{1. 緒 言}

冷延・表面処理プロセスラインでは、歩留向上, 増産対策の 1 つとして、ライン性の押疵欠陥を防止 することが有効である。押疵の主原因は、溶接時のスバッタが鋼板上に残り、これがロールに付着する ためである。そこで、このスパッタを除去する目的で溶接スパッタ除去装置を考案し、昭和 61 年 3 月 当所表面処理ラインに設置し、良好な結果が得られたので報告する。

\section{2. 装置概要}

本装置は、ナローラップシームウェルダ 一直後に設置され溶接完了後、鋼板の溶接 線付近に付着した溶接スパッタを機械的に 除去する装㯰である。

本装置の概要を Fig. 1 に示し、以下動作 について説明する。

溶接完了後、鋼板は所定位置まで送られ、 クランパにて保持される。次にブラシロ一 ルが回転し、装置が鋼板の巾方向に移動す ることで溶接ビードのスパッタを除去する。 この時、鋼板が逃げない様バックアップロ ールで押し付ける。また、発生した研摩ク ズはブラシロール後のワイパーで拭き取る。 尚ブラシロールには砥粒入り合成瀻維製 のものを使用し、バックアップロールには 硬質クロームメッキを施し、ワイパーには、 無砥粒の合成瀻維製のものを使用した。

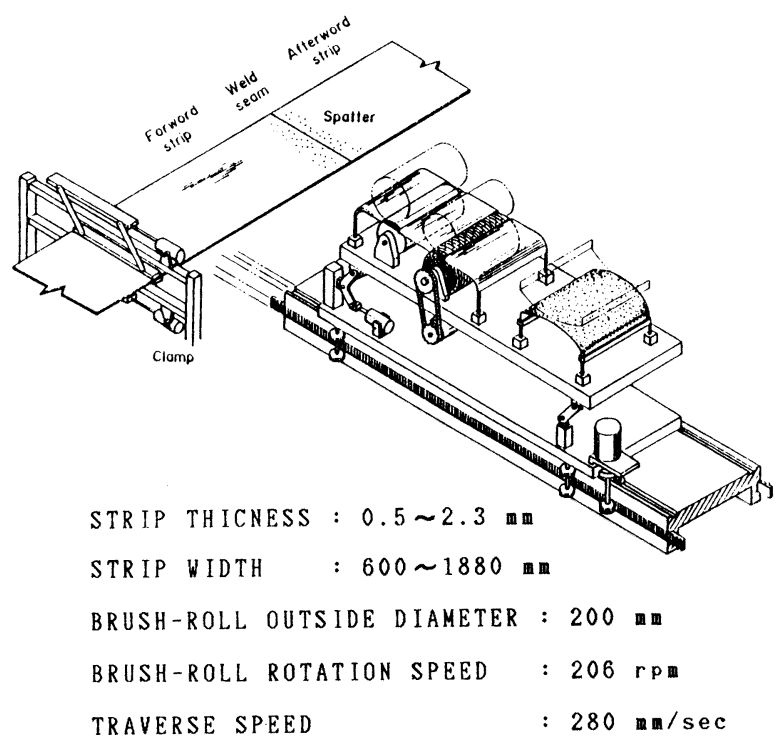

Fig.1 Schematic Diagram of the Weld Spatter Brushing Machine

\section{3. 実績効果}

本装置を当所表面処理鋼板ラインに取りつけ以下の効果が得られた。

1）押疵防止による歩留向上。

2)押疵に絡むライン停止時間の減少による増産。

\section{4. 結 言}

本装置は、押疵の主原因となっている溶接時のスパッタを効率的に除去する目的で開発し、押疵解消 による品質・歩留向上及び手入時間の減少による増産に大きく寄与した。今後は、本装置を重要ライン に払大設置していく方向で進める。 
（306）10 kWレーザー溶接機における放物面鏡の溶接特性と導入後のライン操業状況

\begin{tabular}{|c|c|c|c|}
\hline 川崎製鉄秝 & 千葉製鉄所 & $\begin{array}{c}\text { ○伊藤正彦 } \\
\text { 楖島章也 }\end{array}$ & $\begin{array}{l}\text { 高田正和 } \\
\text { 横沢二男 }\end{array}$ \\
\hline
\end{tabular}

\section{1. 緒 言}

ステンレス連続焼鈍酸洗ライン (KM-APL)の能率向上，歩止り向上を目的として，昭和61年 3 月ょり $10 \mathrm{~kW}$ Wーザー溶接機の稼動を開始した。本設備の集光光学系は当初 $\mathrm{n}$-Se製レンズを使用していたが, 昭和 62 年 4 月より放物面鏡へ変更し, 安定した性能を発揮し, 操業に貢献しているため報告する。

2. 放物面鏡について

Fig. 1 は放物面鏡を用いた溶接機の卜 一チ先端部を示す。レーザー光は平面之 ラ一を用いて $90^{\circ}$ 折り曲げ放物面鏡に入 射し，そてでさらに $90^{\circ}$ 折り曲げ集光す るタイプである。

Photo. 1 はレーザー光が放物面鏡に入 射する前と後とのバーンパターン結果を 示す。入射前のリングモードが入射後に おいても完全に残されており良好な集光

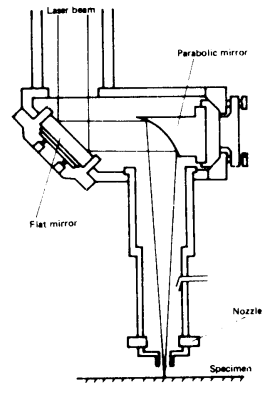

Fig. 1 Schematic diagram of parabolic focusing optical unit.

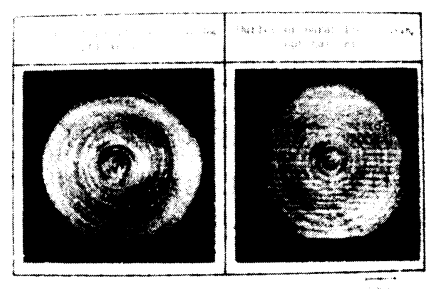

Photo. 1 Burn pattern

系であるととがわかる。入射後に見られる縞嵄模は放物面鏡上に残った切削跡によるレーザ一光の干 涉によるものである。

\section{3.溶接特性について}

Fig. 2 は放物面鏡と， $\mathrm{Zn}-\mathrm{Se}$ 製レン ズとの溶け込み深さを調査したもので ある。また photo. 2 はその溶け込み形 状を比較したものである。溶け込み深 さは，両方とも同様な性能を示してい る。また，溶け込み形状についても， その違いははとんどなく，良好な結果 が得られている。

\section{A P L 操業状況}

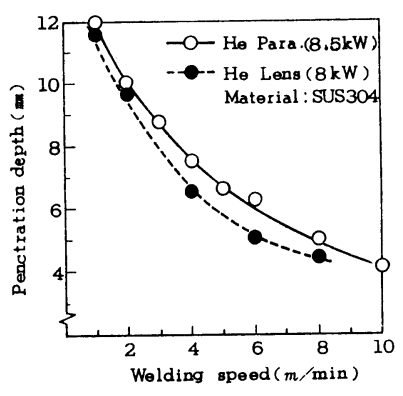

Fig. 2 10kw CO2 laser wolding properties

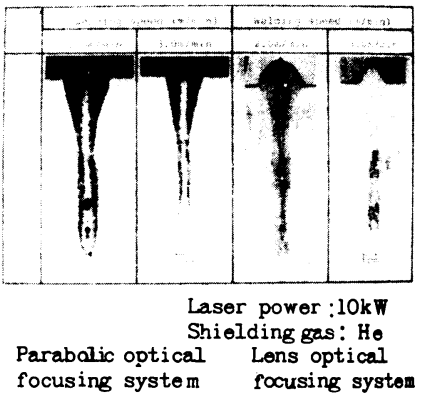

Photo. 2 Penetration shape comparison

Fig. 3 はレーザー溶接機の導入後におけるA P L の生 産量推移を示す。導入前と比較し, 約 $20 \sim 25 \%$ の生 産量増が可能となった。また放物面鏡導入後においても, その生産量に影響はない。

\section{5. 結 贯}

本設備は現在順調に稼動しており, 大出力レーザー溶 接機において放物面鏡は充分にその能力を発揮している。 <参考文献>

1). 伊藤ら; 第 113 回講演大会 $\left(\begin{array}{lll}3 & 83\end{array}\right), 1987$ 山田ら; 昭和 61 年度精密工学会秋季大会 $\left(\begin{array}{lll}8 & 0 & 1\end{array}\right)$

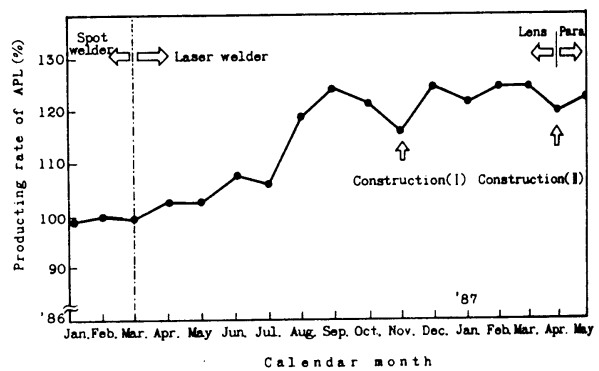

Fig. 3 Producting rate of $A P L$ 


\section{（307）極低炭素鋼フラッシュバット溶接技術の確立}

\begin{tabular}{|c|c|c|}
\hline 奇製鉄株千葉製鉄所 & $\begin{array}{l}\text { ○小川 満 } \\
\text { 中村武尚 }\end{array}$ & $\begin{array}{l}\text { 綿貫正典 } \\
\text { 三宅英德 }\end{array}$ \\
\hline
\end{tabular}

1. 緒言

極低炭素鋼のフラッシュバット溶接において, 従来, 溶接線上に酸化物が残留し,この酸化物を起点 として溶接破断が多発する問題があったが,フラッシュバット溶接機の電源回路構成の変更および溶接 条件の最適化により, 溶接線上の酸化物を除去することに成功し, タンデム圧延にも耐え得る溶接品質 を得たので報告する。

2. 従来の極低炭素鋼 F.B 溶接の問題点

極低炭素銅，特に断面積が 4,500 mat を越える材料のF. B 溶接 において, Photo.1 に示すよ5に, 溶接線上に酸化物が残留す る溶接不良が多発していた。

3. 溶接品質改善へのアプローチとその結果

(1) 電気的溶接条件の溶接品質への影響

溶接条件の5ち, 電気的な条件である後期フラ ッシュ電圧とアップセット電流に着目し, 溶接品 質への影響を調査した。Fig. 1 に従来の溶接機電 源回路構成を示すが, 単巻トランスタップ值と溶 接品質の関係はFig. 2 の通りであり, 極低炭素鋼 溶接品質改善のためには, 後期フラッシュ電压を 低くし、アップセット電流を増大することが必要 であると考えた。

(2)溶接機電源回路構成の変更とその効果

電源回路をFig. 3 のよ5に改造し, 後期フラッ シュ電圧とアップセット電流を独立して制御可能 とした。この回路を使用し, 後期フラッシュ電圧 を低くし，かつ，アップセット電流を増大するこ とにより溶接線上の酸化物を除去することに成功 し, 極低炭素鋼大断面積材においても，健全な溶 接品質を得ることができた。(Fig. 4, Photo 2 参照)

4. 結 言

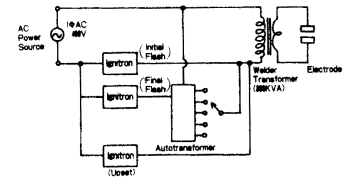

Fig. 3. Improved Electric Circuit of F.B. Welder

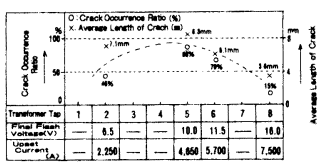

Fig. 2. Conventional Welding Characteristic by Coronical Cup Test

極低炭素鋼フラッシュバット溶接においては, 後期フラッシュ電圧を低くかつアップセット電流を増 大することにより，溶接品質を大巾に改善することができる。この溶接技術を千枼№５酸洗ラインの実 操業に適用しており，良好な結果（溶接破断削隇，歩止り向上等）を得ている。

（参考文献） 1）田沼ら；溶接学会誌第 51 巻（1982）第 5 号

2）田沼ら; 溶接学会誌第 51 巻（1982）第10号 
住友金属和歌山製鉄所信原季男宇都宮憲—加藤郁雄 (鹿島製鉄所线井斉山田富三郎

川之江造機秘石井勇

$$
\text { 本 社 } \bigcirc \text { 佐藤賢治 }
$$

\section{1. 锫 䡒}

和歌山製鉄所冷延工場では、従来自動化の遅れていたコィル相包作業の合理化・高品質化を目的とし て、紙梱包・結束工程を完全自動化した高能率連続コイル梱包ラィン（ＣＰＬ：Coil Packing Line）を 建設し、1 1987 年 3 月より稼動している。以下、本ラインの中で当社が開発・実用化した、自動コイ ル紙梱包設備の設備構成・動作・特長について述べる。

\section{2. 設僧熼成及ひ特長}

本設備の構成は、紙供給・紙巻付・コイルリフト装置から なる外周紙巻設備と、耳折・内面テーピング・コイルリフト 装置からなる耳折設備により構成されている。

又各工程での基本動作は、(1)紙供給工程：C P U 指示に基 き、紙の選定・裁断を行い、巻付軸に供給する。(2)紙巻付工 程：静止コイルの外周上を巻付軸が回動する事により、紙巻 付・端部テーピングを行う。(3)耳折工程：包装紙端を财着板 により保持後、折り畳み・旋回する事により、耳折在行う。 更に余長紙をコイル内筒内に押し込み、テーーピングを行う。 次に本設備の特長を示す。
(1) 高能率 サイクルタイムは約 2 分ノコイル

(2) 高品質 相包姿は手作業以上の見映光 紙端シールは完全密封シール

（3）広範な対応性、多種多様なコイル（サイズ、形状）・ 紙（紙質、紙幅）への対応性大

耳折設備写真を Photo 1 、設備主仕様を T a b l e 1 、設備 動作フローをFig 1 に示す。

\section{3. 結 曹}

本設備は 199887 年 3 月より順調に稼動しており、当初の 効果を発揮している。

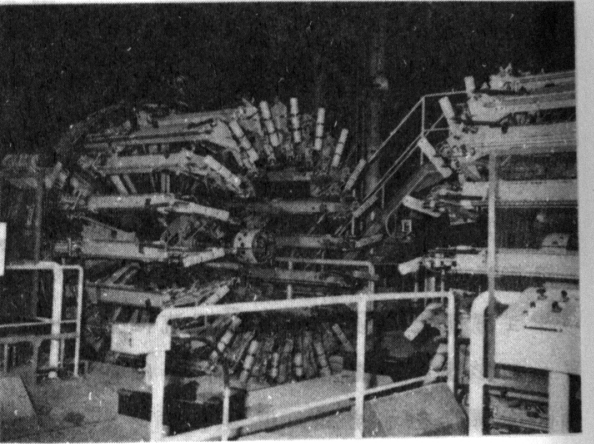

Photo 1 Folding Machine

(a t Wakayama Works) 尚、当社鹿島製鉄所命延工場においても、同様な設備を

Table 1 Specification of Machine

\begin{tabular}{|c|c|}
\hline I tem & Specification \\
\hline Coil diameter & Max.1,900 (m) \\
width & Max.1,830 (mm) \\
Papar width & Max.2,400 (mm) \\
number of rolls & 120 \\
Number of folding & $2(\mathrm{~min} / \mathrm{coil})$ \\
\hline
\end{tabular}
現在建設中である。

$$
\text { Paper Supplying Paper Winding Folding Line }
$$

Fold ing

Inner Taping

\section{(4)}

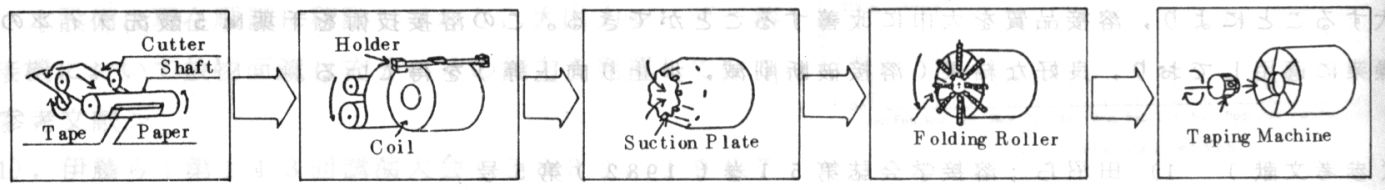

Fig. 1 Operating flow of Packing Machine 
住友金属工業侏 鹿島製鉄所 ○布川 剛 浅井 斉 池田二郎 子安三彦 松田行雄 鶴田和男

1 . 緒言

酸洗鋼板の高品質化，と安定化を目的として，鹿島製鉄所熱延工場に連続酸洗設備を新設して昭和 6 2 年 2 月より営業運転を開始している。本ラインは, スキンパスミルとテンションレベラーの組み合せ により脱スケール向上, 平担向上を図るとともに当社独自の新技術を駆使した最新鋭ラインである。 本報では, 本ラインの設備蔇要とその特徴について紹介する。

\section{2. 設備概要}

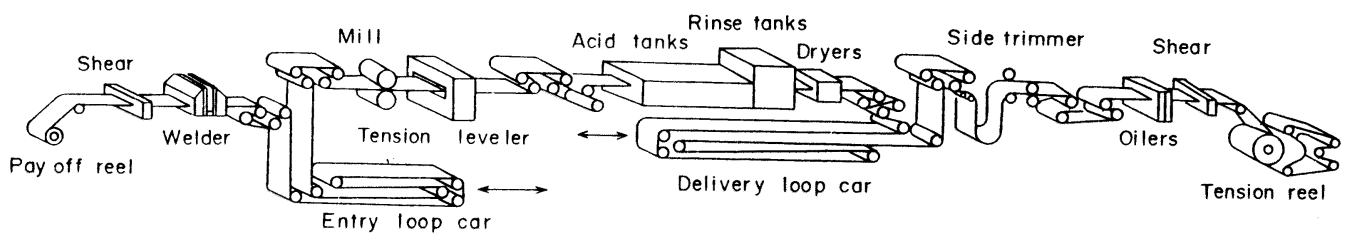

Fig.l Schematic diagram of new pickling line

Fig. 1 に本ラインの構成を, Table 1 にライ ン主仕様を示す。脱スケール設備はスキンパスミ ル,テンションレベラーおよび酸洗槽により構成 される。各々の仕様は,

(1)スキンパスミルとテンションレベラー

伸率値 : $\mathrm{Max} \quad 3.5 \%$
入側張力: $\mathrm{Max} \quad 23 \mathrm{Ton}$
出側張力: $\mathrm{Max} \quad 46$ Ton
スキンパスミル : $\phi 835 \times 2 \mathrm{Hi}$

圧下力: $\mathrm{Ma} \mathrm{x} 1100$ Ton.

(2)塩酸槽 : $20 \mathrm{~m} \times 4$ 槽

である。また, 品質保証機器 ( U S T, 巾計, 厚み 計) や省力設犕 ( 自動塩酸濃度測定器, クロッブ処 理装置, マーキング装置等)を設置している。 3. 脱スケール性

実機脱スケール性につレてFig. 2 にテンションレ ベラーとスキンパスミル使用時のコイル巻取温度と 伸率, 中央速度の関係を示す。テンションレベラー 単独使用時に比べ $20 \%$ の增速効果が得られた。 4. 結言

スキンパスミル設置等の新技術により高品質の酸 洗鎆板の製造が可能となり，威力を発揮している。
Table I Main specification

\begin{tabular}{|l|l|c|}
\hline Strip & $\begin{array}{l}\text { Thickness (mm) } \\
\text { Width (mm) }\end{array}$ & $\begin{array}{c}\text { I.0 } 6.35 \\
610 \sim 1673\end{array}$ \\
\hline Coil weight (ton) & Max 31 \\
\hline & Entry section & 650 \\
Max. line speed & Tank section & 200 \\
(m.p.m) & Delivery section & 350 \\
\hline \multirow{2}{*}{ Strip } & Entry (m) & 350 \\
accumulator & Delivery (m) & 250 \\
\hline
\end{tabular}

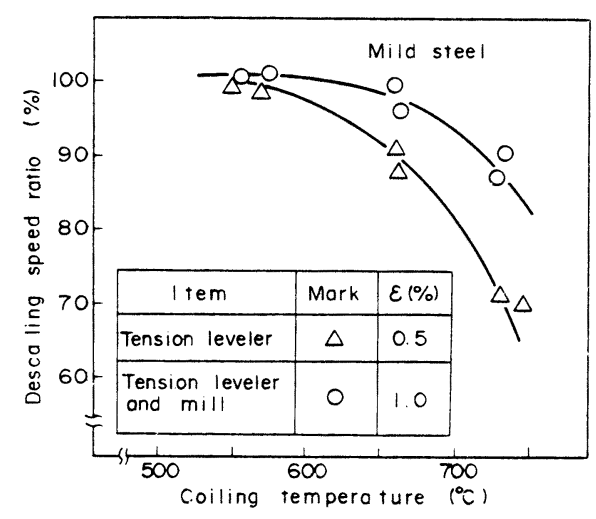

Fig.2 Effect of tension leveler and mill on descaling speed ratio 


\section{1. 緒 言}

当所Na 6 酸洗ラインのテンションブライドル用スナバロールの表面に多角形模様が発生した。そてて多角形 模様の発生機構の解明とその対策を施し、成果を得たので報告する。

\section{2. 設 備概要}

ロールの配列をFig. 1 亿、スナバロールの仕様をTable 1 亿示 す。本ロールは歪み矯正のための高張力を与えるブライドルロー ルと対をなし、鋼板のスリップを抑制するものである。

\section{3. 調查結果}

(1) 損傷口-ル調查

Fig. 2 飞損傷ロールの外観を示す。多角形模様は軸方向に幅 $6 \sim 7 m m$ ピッチで等間隔で発生しているととがわかる。

\section{(2) 振動解析}

スナバロールおよび付带設備の振動を測定した。Fig. 3 スス ナバロールの振動解析の一例を示す。その結果、振動の大きさ は通常のライン速度付近で急激に増加し、ブライドル減速機の 嚙合ら振動数とスナバロールの固有振動数とが一致していた。

\section{4. 原因の推定}

以上の結果から、乙の多角形模様はブライドルロール減速機の 嚙合ら周波数とスナバロールの固有振動数との共振でスナバロー ルと鋼板の間に周期性の微小すべりが発生し、多角形模様になっ た。のと考えた。

\section{5. 対 策}

対策としては以下の 3 つの案を検討した。

(1) スナバロール固有振動数の変更に上る共振現象の防止

(2) スナバロール押付け圧力の強化に上る微小すべりの軽减

(3) スナバロール表面性状の変更に上る耐摩耗性の向上

(1)につレては、その他の歯車との共振および構造上の制限のた めに困難であった。(2)につんては、1.5 倍の押付け圧を加えたが 大きな効果は得られなかった。(3)につんては、一般に微小すべり 摩耗は凝着摩耗とアブレッシブ摩耗の複合現象と言われているの で、いずれに対しても耐摩耗性に優れる自溶性合金の溶射処理を スナバロールに施した。

\section{6. 結 言}

スナバロール表面に自溶性合金の溶射処理を施すことにより、 多角形模様は低減し、6〜7倍の寿命延長効果を得た。

参考文献 1) 佐藤ら: 潤滑学会研究発表会 B·18 (1983.10)

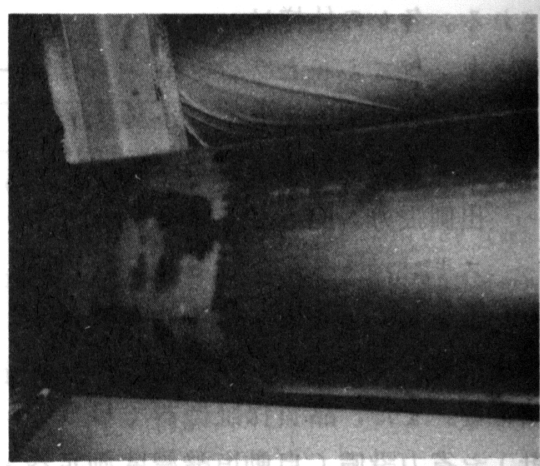

Fig. 2 Surface of damaged roll

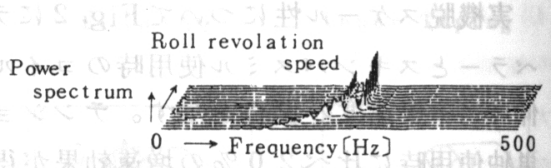

Fig. 3 Vibration analysis 
1. 緒言

近年、ホットストリップミルでのステンレス鋼板の圧延において、薄肉化、コイル単重増、表面品質 の高級化等により圧延ロールの表面性状向上が課題となっている。その対応策として油圧延、压延機の 負荷調整等の圧延条件の改善とロール材質の改善がある。本報では、黒鉛晶出型ハイクロムロール ${ }^{2)}$ を実機に用レオーステナイト系ステンレス鋼板での耐肌荒性と、更に本ロールを普通鋼に適用した場合 の耐摩耗性につレて以下に報告する。

2. ロール肌荒れの現象と発生メカニズムの 推定 従来型の $18 \% \mathrm{Cr}$ 鋳鉄ロールで、オーステナイト系ス テンレス鋼板を苛酷な条件 (圧下荷重大、圧延長大等) で圧延すると、Photo 1 に示す様なV字状のスクラッチ 疵が仕上ミル前段ロールの表面に発生する。軽微な場 合は鋼板の通板部エッジ近傍に発生し、程度が酷くな ると通板部全面に発生し鋼板表面の欠陥となる。この 疵は、Photo1.に示す如く微小な凹凸を呈し、一部に圧 延材が焼付いている事すある。この発生機構は、ロー ル表層部のミクロ的な欠落と、それを起点として、線 状疪が発生し、それが成長、集合しV字状疵になると 推察される。ロール表層部での、この微細疵の集合作 用を防を゙圧延材とロールの金属的局部接触を均一な接 触にする事を目的に、金属組織中に黒鉛が均一に分布 する（面積率で 7〜9\%) ハイクロム鋳鉄ロールを使 用した。その結果本ロールではV字状の疵が発生しな かった。その理由は黒鉛の作用による均一摩耗と自己 潤滑による摩擦抵抗低減の効果と推察される。Photo 2 に本ロールの圧延前後の断面を示すが、压延後微細 な黒鉛が脱落している。

3. 実機使用結果

オーステナイト系ステンレス鋼板の压延に本ロール を仕上前段スタンドで使用した結果、V字状肌荒れは 発生せず、ロール肌評価は $18 \% \mathrm{Cr}$ 鋳鉄ロールに較へ、 $40 \%$ 向上している(Fig. 1)。また、同じく普通鋼圧延

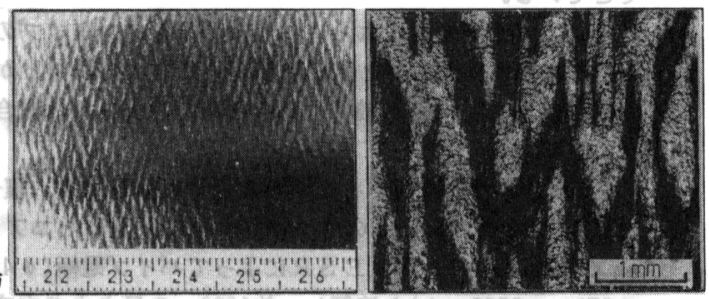
$\begin{array}{ll}\text { (A) macro graph (B) micro graph } & \text { (B) }\end{array}$ Photo I. The example of roll surface deterioration left out grophite

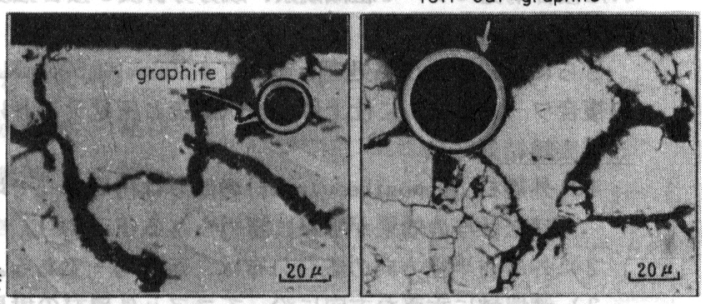

(A) before rolling (B) after rolling

Photo 2. The cross sections of roll showing the lubrication by graphite contained in roll

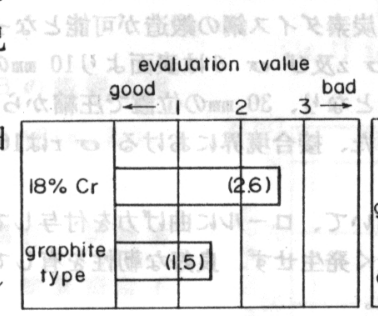

Fig.1. The evaluation of roll surface deterio ration (sus 304 )

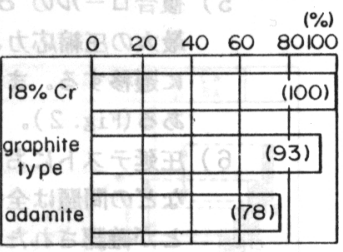

Fig 2. The comparison of roll yield ( mild steel)

では、耐肌荒性、耐摩耗性、耐事故性とも $18 \% \mathrm{Cr}$ 鋳鉄ロールと略同等である。(Fig.2)。

4. 結言

オーステナイト系ステンレス鋼板の表面品質改善のため、黒鉛晶出型ハイクロムロールを適用し良好 な結果を得た。また本口ールは普通鋼圧延においても良好である。

参考文献 1)橋本ら，鉄と鋼，71 85-S1113，2)橋本ら，鉄と鋼，73 '87-S364 
（3１2）回転付与EＳR外圈肉盛法による椱合ロール の唓造造

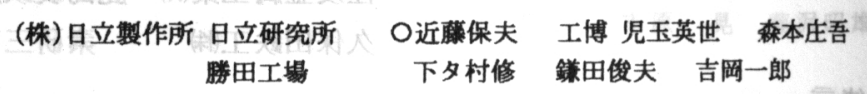

\section{1. 緒言}

冷間圧延用ワークロールは、压延条件の過酷化に伴ってそれに酎えうる硳摩耗性と強度及び勒性を同時に具暴してい

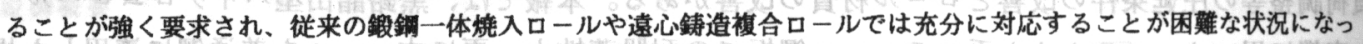
てきている。

そこで、筆者らはこれらにおきかわる新しいタイプのロール製造法として、回転付与E S R外層肉盛法を開発し、聇 摩耗性に優れた外㬝材と強度及び勒性に優れた軸材とから成る襀合ロールの検討を進めてきた。 ${ }^{122)}$ 本報では、外層 材が高炭素タイイス鋼、軸材が低合金鎆で構成された複合ロールの製造過程及び性状について報告する。

\section{2. 実呀方法}

Table 1 にコア及びパイプ電極の化学成分を示す。複合鋼塊

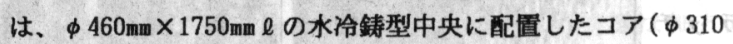
$\mathrm{mm} \times 2400 \mathrm{~mm}$ \&)の外周にE S Rによってパイプ電極 ( $\phi 419 \mathrm{~mm} \times$ $\phi 370 \mathrm{~mm} \times 3525 \mathrm{~mm}$ \&) を溶解し、約 $1200 \mathrm{~mm}$ の長さまで肉盛を行っ て製造した。電極溶解中は、コア及び鋳型を回転させた。得ら れた複合鋼塊について組織锶察、成分分析及び接合強度の評価 等を行った。

さらに、錙造及び熱処理を施して $\phi 300 \mathrm{~mm} \times 1575 \mathrm{mmBL} \times 3210 \mathrm{~mm} T \mathrm{TL}$ の複合ワークロールに仕上げ、性状調查と圧延テストに供した。 3. 実倹結果

1) 外層材 (Deposited layer)の厚みは円周方向で均一であり。 回転付与の効果が明瞭に認められる(Fig. 1)。

2) 外層材半径方向の成分分布は、ほぼ均一である。

3）鋼塊軲に垂直な方向に沿ってコアと外層材の境界を含む試 験片を採取して曲げ及び引張試験をした結果、破断はいず れも接合境界では生ぜず、接合性は良好である。

4) 複合化することにより、従来の一体大型ロールでは非常に 困䙵であった高炭素タイイス䤡の鍛造が可能となった。

5）椱合ロールの $\boldsymbol{\sigma}$ 㚫び $\boldsymbol{\sigma} \theta$ は表面より $10 \mathrm{~mm}$ の位置で 最大の圧鏥応力となり、30 mmの位置で圧綟から引張応力 に遷移する。また、接合境界における $\sigma$ rは160 MPaで ある(Fig. 2)。

6) 压延テストにおいて、ロールに曲げ力を付与しても折損 などの問題は全く発生せず、良好な勒性を有しているこ とが確認された。

\section{〔参考文献〕}

1) 近藤ら：鉄と錳，70 (1984) S232

2) H.Kodama et al : 8th ICVM, 2 (1985) p. 1207
Table 1 Chemical compositions of core

\begin{tabular}{|l|c|c|c|c|c|c|}
\multicolumn{4}{c|}{ and electrode. } \\
\hline & $\mathrm{C}$ & $\mathrm{Si}$ & $\mathrm{Mn}$ & $\mathrm{Cr}$ & $\mathrm{Mo}$ & $\mathrm{V}$ \\
\hline core & 0.91 & 0.58 & 0.70 & 3.01 & 0.18 & - \\
\hline electrode & 1.80 & 0.35 & 0.50 & 12.8 & 0.90 & 0.90 \\
\hline
\end{tabular}

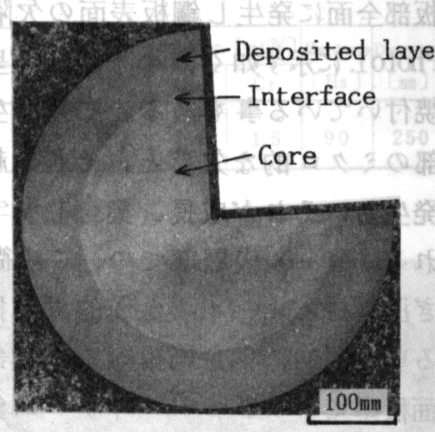

Fig. 1 Macrostructure of clad ingot.

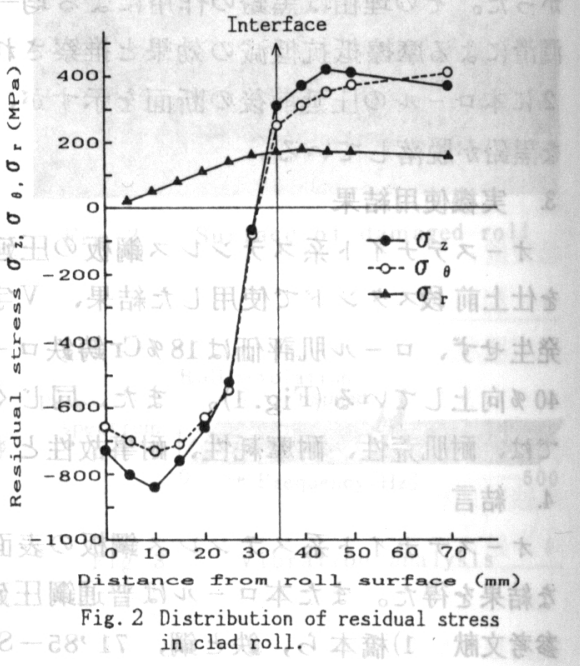


' $87-$ S 1049

（3｜３）調页圧延における防錆性能を有する高洞滑型調圧液の荓発

$\begin{array}{lllrl}\text { 日本鎆管 (株) 福山製鉄所 } & \text { 谷口 } & \text { 熟 } & \text { 古資 } & \text { 洋一 } \\ & \text { 尾崎 } & \text { 大介 } & \text { ○大藤 } & \text { 浩 } \\ \text { בシ口化学工業 (株) } & \text { 武藤 } & \text { 俊美 } & \text { 黒井 } & \text { 信臣 }\end{array}$

1. 緒 言

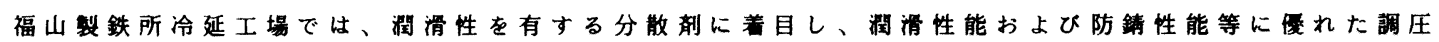

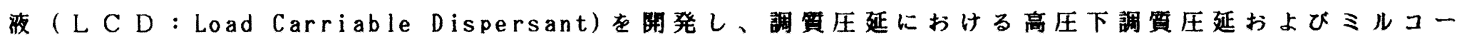
卜压延（防錆圧延）にその適用を試みた。その結果、良好な結果が得られたので報告する。

2. L C D の特性

L C D の特性としては、以下のものが挙けられる。

高压下調圧性能：圧下集1 25\%間で安定压延可。

防錆性能: 压延後、3 月以上の防錆能力尼 有する。 ミルクリーン性能：油分・鉄分付着量少。 表面ブライトネス：ストリップのブライ トネス良好。

製品望装性能: 压延後、無脱脂で鉒密着性良好。

L C D の組成 : $\quad \mathrm{Nc}-\mathrm{C} x-\mathrm{Na}-\mathrm{C} y-\mathrm{Nb}$

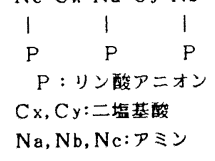

3.高压下調圧およひミミルコ一ト圧延における道用の背景と結果 $\mathrm{Na}, \mathrm{Nb}, \mathrm{Nc}:$ アミン

(1) 高压下調压

プキ・TF S 材はその用途心応じて規格があり、硬度筑囲 が規定されている。現状は規格に応じて、素筑成分・焼鈍条件 を変更して製造しているが、これを同一素材ょり調圧の伸張率 条件の変更のみで作り分けることができれば、大きなメリット が期待される。

。压下來と压延荷重

ほぼ比関係にあり、圧下率 $25 \%$ まで安定探䍲可能。(Fig.1)

また、压延速度变化に対しても安定した洞滑性能を示した。

。圧下率とストリップ硬度

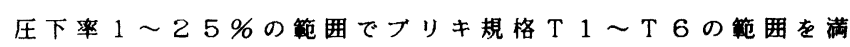

足しており、ブリキ材製造に道用が可能である。(Fig．２）

(2) ミルコ一ト压延

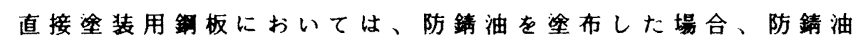
の過多、ムラにより需要家において、塗装ハジキ、染装密着不 良が生じることがある。このため、鎆板表面に溥く均一な防錆 皮瞙亚形成することが必要である。

。防錆性能、塗装性能、油分 - 鉄分付着量

現行のドライ調圧後、防錆油を枚布したものと比較して、

いずれの点においても優っており、優れた性能を示した。

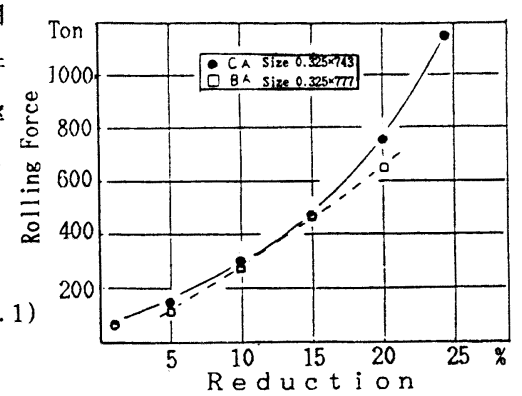

(Fig.1) Reduction and Rolling Force

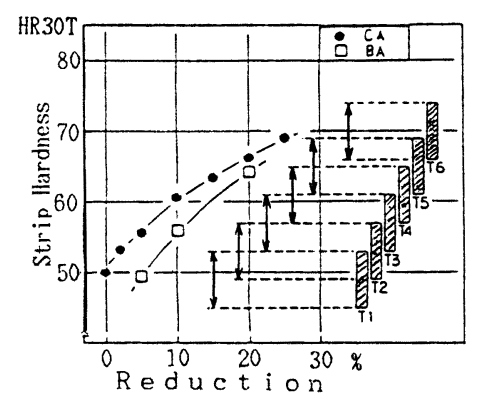

(Fig.2) Reduction and Strip Hardness

4. 結 言

今回の L C D 開により、高圧下拥圧およひミルコ一ト圧延を安定して行うことが可能となった。 今後は、上記用途に対し、当L C D を㮴的に拡大していく方針である。 


\section{（3｜４） 中径E RW極厚龬管の製造技術}

川崎製鉄侏) 知多製造所 $\bigcirc$ 杉江善典 冨永博友 渡辺修三 徳田政昭 富沢良信 井手 勉

1. 緒言

鉄鋼研究所豊岡高明

近年、中径 E R W 鋼管の需要は、High-Grade・厚肉化の傾向が著しい。当社では、この需要傾向に 対処すべく、26" E RWミルの設備増強、製造技術改善を実施し、極厚材の製品化に成功した。本 報では、極厚材製造上の対策および品質特性について述べる。

2. 対象材

S T K $50 \quad 355.6 \sim 6 \quad 6 \quad 0.4^{\phi} \times 22.0^{\mathrm{t}}$

3. 製造上の対策および品質特性

(1) エッジトリミング

従来のサイドトリマーにかわり、エッジミラーを 使用することにより、エッジダレ、タングの発生を 防止でき、溶接品質の向上が図れた。

(2) ケージフォーミングによる極厚材成形

エッジヘンド長さ、ケージ内インサイドロール設 定条件の適正化により、角張りの小さい $1 \mathrm{~F} \mathrm{P}$ 前フ ラワーを確保した。その結果、1 F P リダクショ ンを従来の $2 / 3$ にすることが可能となり、設備強度上 のネックとなる 1 F P の成形荷重の低減化が図れた。 また、ケージ内ローリング防止用ガイドロールを配 置することにより、極厚材のローリングを防止した。 (3) 溶接

肉厚が厚くなるにつれ、必要なアプセット量は增 大する。これについては、両持タイプの $\mathrm{S} Q$ スタン ドにより対応した。また、厚肉材で悪化する傾向の あるコンタクトナップ疵防止対策としては、コンタ クトチップの冷却効率向上、圧下力の強化、追従性 の向上を目的としてウェルダー圧下機構部の改造を 実施した。

(4) 内面ビ - ド切削

強アプセットの結果、内面ビードが大型化する。 この大型ビード切削時のバイト破損を防止すべく、 タンデムバイト式ビードカッターを適用し、バイト 1 ヶあたりの切削負荷の軽隇化をはかった。

4. 結言

上記製造上の対策を実施することにより、肉厚 $22 \mathrm{~mm}$ 材が製造可能となり、良好な溶接品質、寸法精度、表 面性状が得られた。

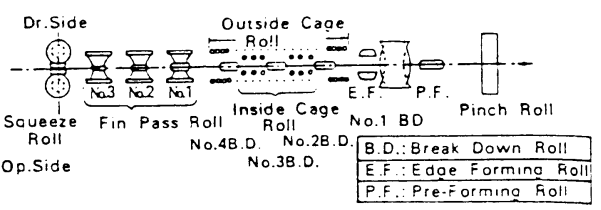

Fig.1 Layout of 26 inch cage forming ERW pipe mill

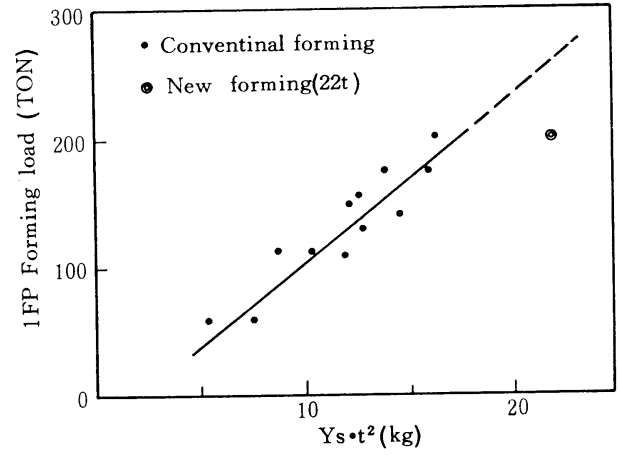

Fig. 2 Comparison of IFP forming load

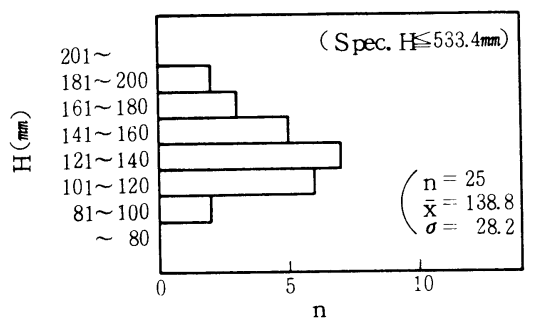

Fig.3 Result of flattening test $(609.6 \times 22.0)$

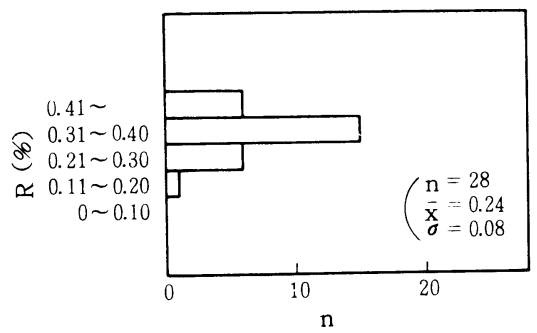

Fig. 4 Actual data of Ovality $(609.6 \times 22.0)$ 


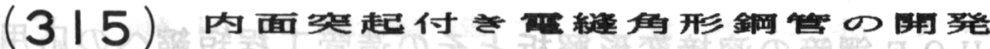

日本鋼管（株）京浜製鉄所 ○小岛其昌 微朗 鈴木 征治

\section{鉄鍊研究所松村弘道}

\section{1. 緒言}

コンクリートとの付着强度及び网性などが優れている為、近年、土木・建策用秦材として、高い突起高さを有する突起

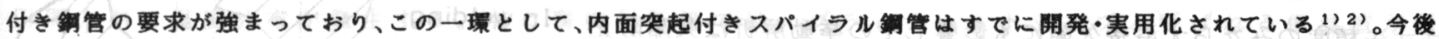

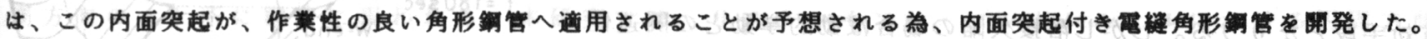
2. 内面突起形状

内面突起のパターンは、楟銅板と同楟のチェッカー方式であり、突起形状の一例を、Fig.1に示す。また、今回製造した 熱延コイルの突起の寸法をTabl.1に示す。

\section{3. 造結果}

3. 1 縟处理法： 处理は、ロータリーシャーで行なったが、その 祭刃にて㔖起を圧延し、板のエッジが波状に変形しない㥞に実施した。 3. 2 溶接：内面突起が付いている為、板厚量いの溶接と、同 じ板厚での溶接とが連䌇的に綝り返されることになるが、Photo.1に 示す断面㛟鏡結果より明らかなように、板厚量いの堨合にも溶融ビー ドがきちんと排出されている。また、屚平試験の結果は良好であり、 $3 \mathrm{tR}$ で実施したガイドベンドテストの結果、割れの発生が無く良好であ った。カイドベンドテスト結果の一例をPhoto.2に示すが、これょり
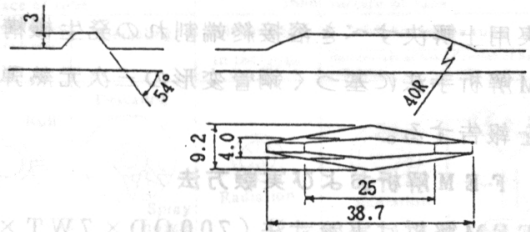

Fig.1. Shape of Rib (300中 $\times 4.5$ ) Table 1. Dimension of Coil with Ribs

\begin{tabular}{|c|c|c|c|}
\hline \multirow{2}{*}{ Pipe Size } & \multicolumn{2}{|c|}{ Dimension of Coil } & \multirow{2}{*}{$\frac{\text { Rib Height }}{\text { Thickness }}$} \\
\hline & Thickness & Rib Height & \\
\hline 200 中 $\times 3.2 t$ & $3.2 \mathrm{~m}$ & $2.0 \mathrm{~m}$ & $62.5 x$ \\
\hline 300 中 $\times 4.5 t$ & 4.5 & 3.0 & 66.7 \\
\hline 300 中 $\times 6.0 t$ & 6.0 & 3.0 & 50.0 \\
\hline
\end{tabular}

明らかなように、溶接品㕢には間題が無いことが わかる。

3. 3 寸法: 今回製造した、電䋖角形鎆管 の寸法測定轺果をTabl.2に示す。これより、JIS の角形鋼管の規定を満足していることがわかる。 4. 結言

角形鋼管としての品貫を満足する、内面突起

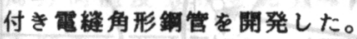
参考文嗝

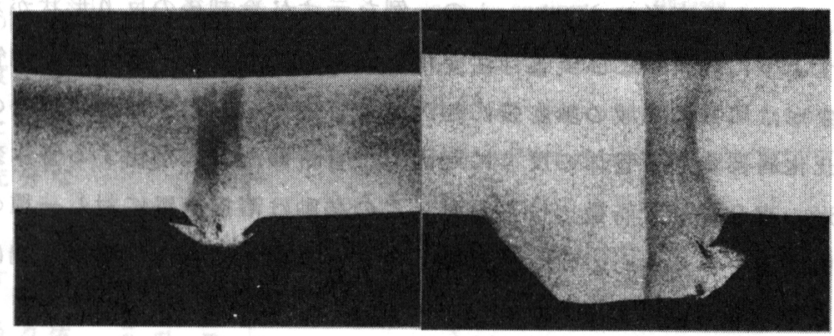

(a) Sane Thickness

(b) Different Thickness

Photo.1. Macrostructare of Velded Portion (300中 $\times 4.5 t$ )
1) 升田ほか:日本鎆管技報 No.107(1985),P.31

2）廣瀬ほか：日本鐝管技報 No.107 (1985),P.46

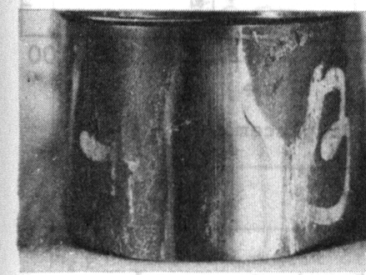

(a) Guided Bend

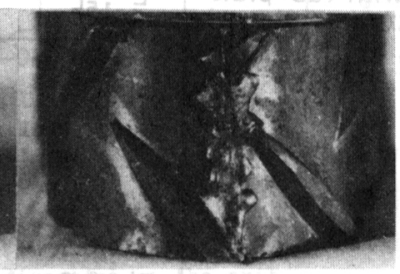

(b) Reverse Bend
Photo. 2 Results of Guided Bend Tests ( $R=3 t / 300$ 中 $\times 4.5 t)$
Table 2. Dimension of Square Pipe

\begin{tabular}{|c|c|c|c|}
\hline Pipe Size & 200 中 $\times 3.2 \mathrm{t}$ & 300 中 $\times 4.5 \mathrm{t}$ & 300 中 $\times 6.0 \mathrm{t}$ \\
\hline Length of & $200.0=$ & $300.4=$ & $300.8 \mathrm{~m}$ \\
\hline side $\mathrm{H}$ & 200.0 & 299.5 & 300.0 \\
\hline Thickness & $3.1 \sim 3.3 \mathrm{~mm}$ & $4.5 \sim 4.7 \mathrm{~mm}$ & $5.9 \sim 6.1 \mathrm{~mm}$ \\
\hline $\begin{array}{l}\text { Unevenness of } \\
\text { flat plate } \\
\text { portion for } \\
\text { each side }\end{array}$ & $\begin{array}{l}-0.25 \sim 0 \mathrm{~m} \\
(<1 \mathrm{~mm}=0.5 \%)\end{array}$ & $\begin{array}{c}-0.5 \sim-0.6 \mathrm{~mm} \\
(<1.5 \mathrm{~mm} \\
=0.5 \%)\end{array}$ & $\begin{array}{c}-0.6 \sim-0.7 \mathrm{~m} \\
(<1.5 \mathrm{~mm} \\
=0.5 \%)\end{array}$ \\
\hline $\begin{array}{l}\text { Dimension at } \\
\text { corner: } \mathrm{S} \text { value }\end{array}$ & $\begin{array}{c}13 \text { max } \\
\left(<3 t^{*}\right)\end{array}$ & $\begin{array}{l}19=\operatorname{Max} \\
\left(<3 t^{*}\right)\end{array}$ & $\begin{array}{c}20=\operatorname{Max} \\
\left(<3 t^{*}\right)\end{array}$ \\
\hline
\end{tabular}

$t^{*}=$ Thickness + Rib Height ( ) : Specif ication of JIS 


\section{（3１6） U ０ E 鋼管の溶接変形解析とその造管工程短縮への応用}

川崎製鉄鉄鋼研究所

千葉製鉄所

\section{1. 粕 票}

U O E 鋼管のストレートシーム溶接熱応力で発生する管形状変化 は寸法精度のみならず溶接欠陷にも影隌しその挙動解析は欠陥防止 有効手段となりらる。しかし溶接欠陥の場合は動的挙動との関連性 が強く熱弾塑性の経時解析が必要で解析法は複雑でその応用例は少 ない。本報は溶接工程能率の大幅向上に有効なタブ板溶接付け省略 の実用上解決すへさ溶接終端割れの発生機構解明と防止法導出に F E M 解析手法に基うく鋼管変形の三次元熱弹塑性解析を応用した結 果を報告する。

\section{F E M 解析およひ実験方法}

F E M 解析は実管寸法 $(7000 \mathrm{D} \times 7 \mathrm{~W} \mathrm{~T} \times 12000 \mathrm{~L})$ を設定し注 目する管端容接終端部ほど小分割とする不等分割に上り入熱 $2 \mathrm{~kJ} /$ $\mathrm{cm}$, 速度 $2 \mathrm{~m} / \mathrm{m}$ in の内面溶接をシミュレートした。

溶接終端割れの発生挙動調査では実管ならびに鋼管と同等変形が 発生するよら拘束した同厚の平板を適宜用い $20 \mathrm{~kJ} / \mathrm{cm}, 2 \mathrm{~m} / \mathrm{min}$ の 三電極 S AW法で溶接した。

\section{3. 結果と考察}

Fig. 1 亿変形シミュレートの一例を示すが冷却後の反り形状が示 すように経験および実管寸法変化と経時的にもよく一致した。鋼管 変形は溶接済領域の熱膨張に起因して管外へせり出す溶接点前後の 凸化局部変形と管体の反りに起因して管断面円が偏平化する管体変 形の複合挙動で特徽づけられた。この挙動は溶接金属に対し一種の 曲げ歪を与え（Fig. 2)、歪速度，量とも自由端である溶接終了端ほ ど助長されるととがわかっ た。割れは破面形態から凝 固割れで、前述の歪発生時 期が管端で溶接金属の脆化 温度域 ( B T R ) 通過と同 期して起こる。適正方法で はこの歪を完全防止でをた (Fig. 3 )。

\section{4. 結 春}

鋼管溶接変形解析に基う く終端割れ機構解明と防止 法導出によりタブ板取付け 省略を可能とした。

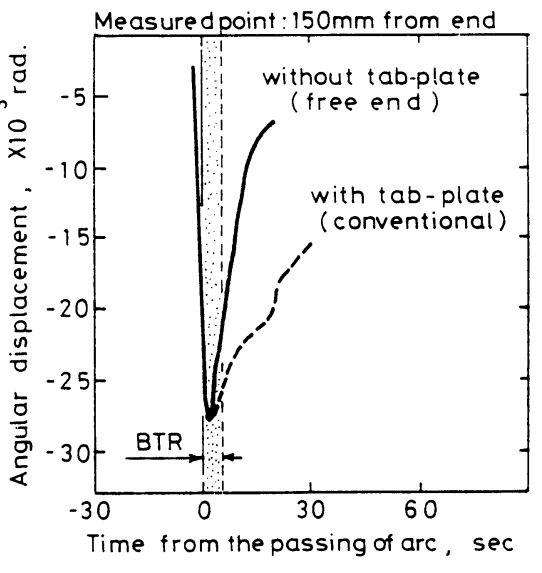

工博

○川端文丸, 松山隼也 村上宗義, 安原勇

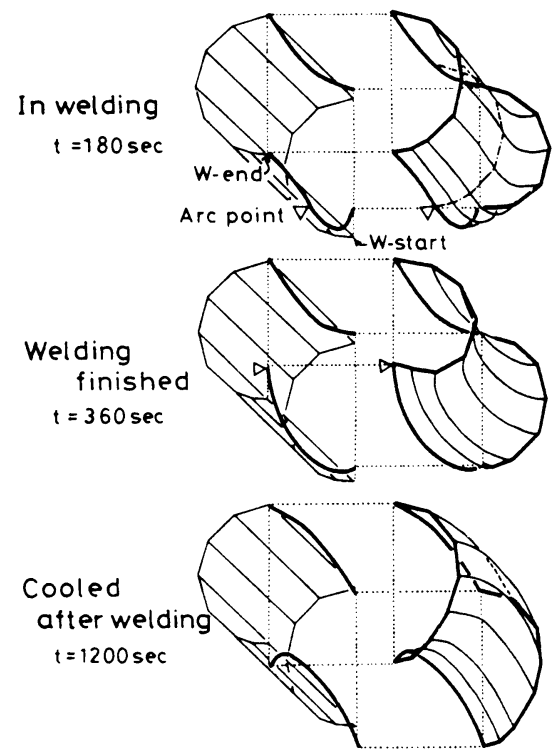

Fig. 1 Thermal deformation of pipe contour during and after welding.

(FEM - s imulation results)

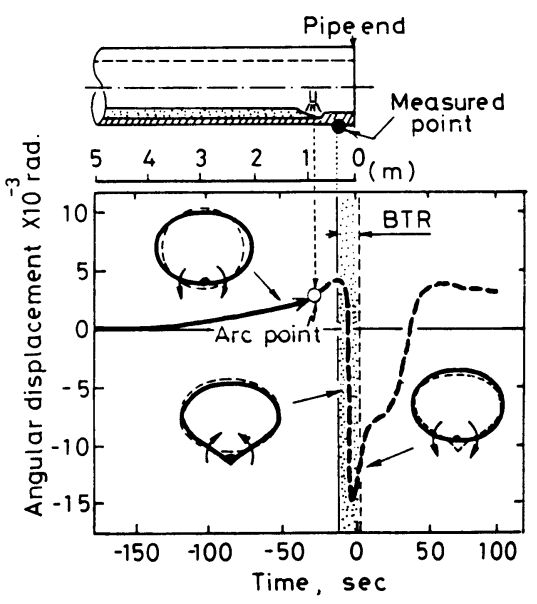

Fig. 2 Angular displacement of the seamline

Fig. 3 Comparison between angular displacements corresponding to three different restrictions to pipe end 
'87-S 1053

(317)継目無造プロセスにおける温度解析

$\begin{array}{llll}\text { 日本铜管 } & \text { 鉄龬研究所 } & \text { ○平川 } & \text { 智之 } \\ \text { 日本铜管 } & \text { 中央研究所 } & \text { 宇田川 } & \text { 辰郎 }\end{array}$

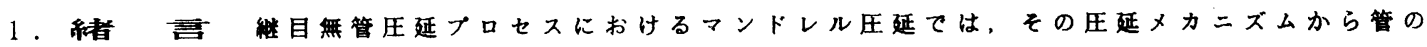
円周方向に温度分布が発生する。特に薄肉材延ては、ブラック・ストライプと呼ばれる低温域が円 周方向の4ケ所に顕著に現われる。本研究ては、リストレイント・マントレルミルにおける円周方向 温度差を予测てきる解析法を開発し，実機ての测温結果と比较を行なった。

2. 解析手法管温度は, 生延プロセ スを通して联送時の空冷，工具との接触領域て の弯熟，圧延時の加工に伴う発熱などにより䙡 雑に变化する。本解析ては，压延プロセス全体 を境界条件が变化するポイントで分剖し，表. 1 に示すような境界条件て熟伝筫方程式を解いた

\begin{tabular}{|c|c|c|c|c|c|}
\hline \multicolumn{3}{|c|}{ Outer surface of tube } & \multicolumn{3}{|c|}{ Inner surface of tube } \\
\hline \multirow{2}{*}{$\begin{array}{l}\text { Natural } \\
\text { cooling }\end{array}$} & \multirow{2}{*}{$\begin{array}{l}\text { Ileas dissipstion by } \\
\text { contact with rolls }\end{array}$} & \multirow[t]{2}{*}{ Descaling } & \multirow{2}{*}{$\begin{array}{l}\text { Without bar } \\
\text { in the tube }\end{array}$} & \multicolumn{2}{|c|}{ With bar in the tube } \\
\hline & & & & $\begin{array}{l}\text { Non-contact of bat } \\
\text { will tule }\end{array}$ & $\begin{array}{l}\text { Conact of bat wili } \\
\text { tube }\end{array}$ \\
\hline Convection & & & & & \\
\hline Radiation & & $\begin{array}{l}\text { Spra } \\
\text { nozzl }\end{array}$ & Radiation & Radiation & $\frac{1}{\text { Lubricant }}$ \\
\hline
\end{tabular}

3. 解析結果之测定結果 $\infty$ 比較

当社中䅅管工場における温度测定と解析を行 なった。図、1には圧延プロセスを示す。マント レルミルての円周方向温度测定はマンドレルミ ル出侧 $1 \mathrm{~m}$ 後方て走查型放射温度計で测定した 。図.2てはマンドレルミル入侧寸法 $\phi 192 \times \mathrm{t} 22$ . 1, 出侧寸法 $\phi 155 \times \mathrm{t} 8.1$ の管温度分布の测定 例を示す。最高温度と最低温度の差は66度で る。図.3で各肉厚，外径の管を圧延した場合 の解析結果と测定結果の比较を行ない，充分な 精度て予测か可能であるとをを示した。

4. 結 票 マントレルミルで発生する円 周方向祖度分布を充分な精度て解析てきる方法 を開発した。

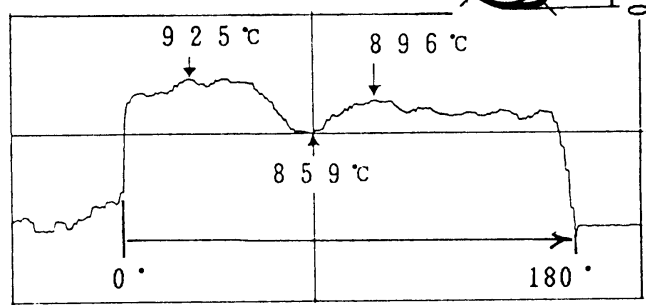

Fig.2 Measured result of temperature distribution in circumferential direction at the exit of No. 8 stand

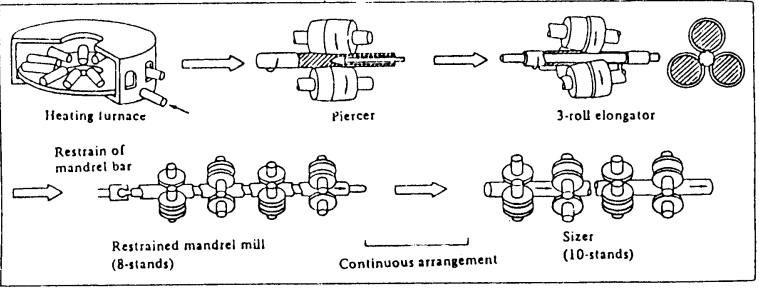

Fig. 1 Rolling process of medium seamless tube mill at Keihin Works

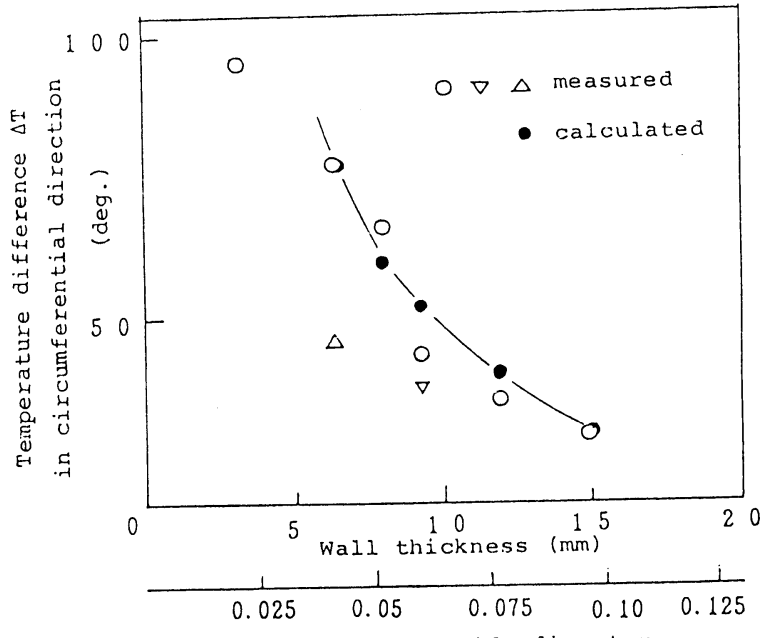

Wallthickness/outside diameter

Fig.3 Measured and calculated results of temperature difference in circumferential direction at the exit of No. 8 stand of mandrel mill 
' $87-\mathrm{S} 1054$

(3।8)

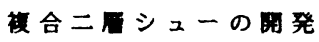

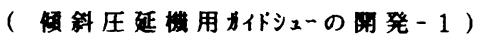

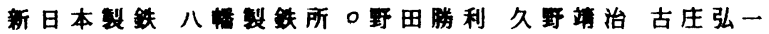
フラント事莱部斉霹弘道大友清司荒田弘人

1. 䋖 言

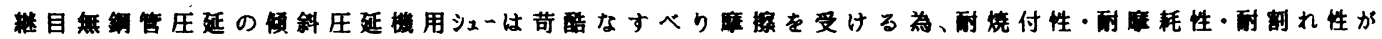

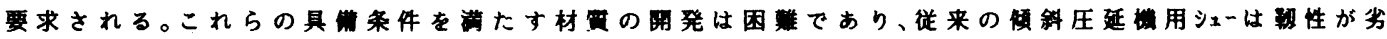
っていた。そのため制れが多く発生し、寿命が安定しなかった。

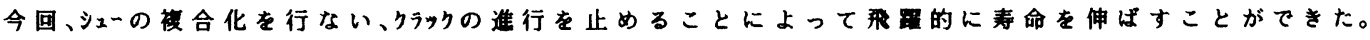

\section{2. シューの特性}

图1にシューの使用状況を示す。シェル上下のロールとフラクで半回転毎

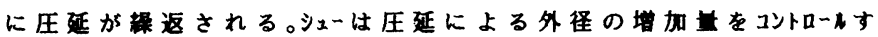
るため苛䀡なすべり麻接を受ける。耐烧付性・耐度耗性から成分 的に野性がなく、加えて高温・高負荷にさらされる為にシューは制 れる。従って酎割れ性の向上が必要である。

3.ニ原シューの製造方法とテスト䊅果

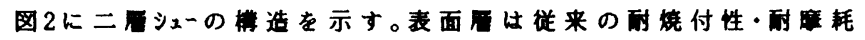

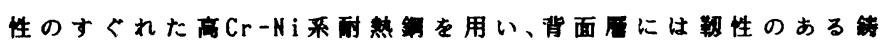
制を用いる。表面展に発生したクラックは背面管との境界面で止ま る。図3に二西シュ一の宑造方法を示す。背面材を垂直に固定し、背

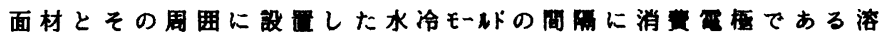

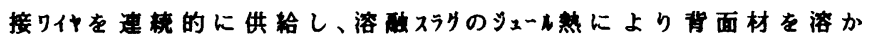
す。背面材が所定の昷だけ溶けたとき、别の溶解妒で予め溶解望 傮した湯を一定速度で唀加し、表面展(highalloy)を形成する。

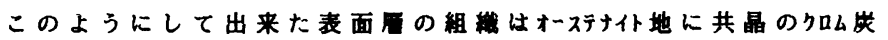
化物が均一に晶出した組樴をしており、従来品に比べて微湅に なっている。图4に二再シュ一の接合部の写真を示す。接合部の強度 は図5に示す漛に背面材より強固なことがわかる。

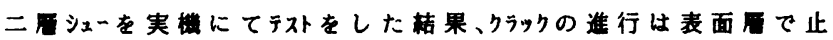
まり、図6に示す樣に2倍以上の寿命を得る事が出来た。加えて高

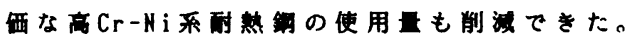

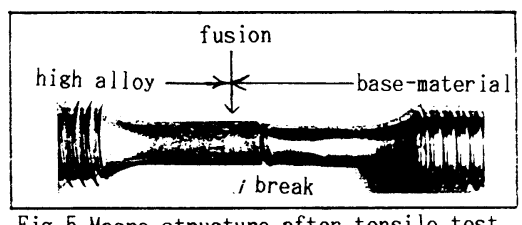

Fig.5 Macro structure after tensile test

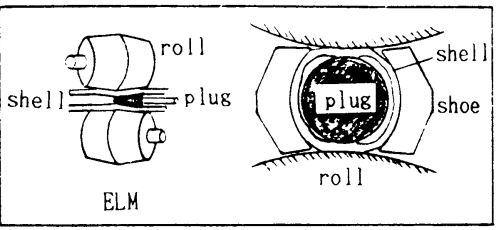

Fig. 1 Function of shoe

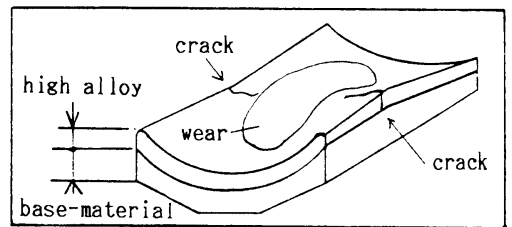

Fig.2 Structure of clad shoe

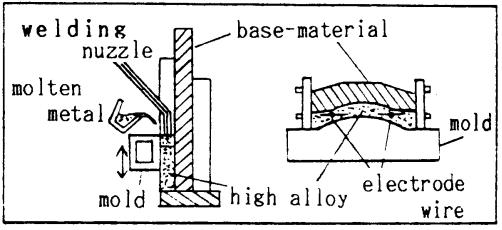

Fig. 3 Manufacturing process

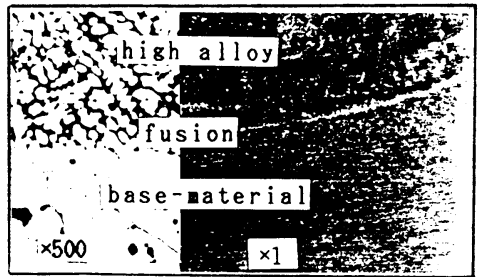

Fig. 4 Micro structure of fusion zone

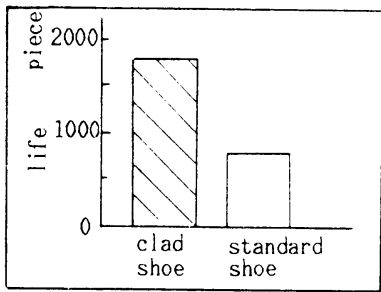

Fig. 6 Comparision of life 


$\begin{array}{lrlrr}\text { 日揮(侏) } & \text { 賀川 } & \text { 直彦 } & \text { 秋沢 } & \text { 清一 } \\ \text { 第一高周波工業(怢) } & \text { 高岸 } & \text { 正章 } & \text { 松原 } & \text { 洋一 } \\ \text { 新日本製鐵(㑣 } & \text { ○井上 } & \text { 靖介 } & \text { 直井 } & \text { 久 }\end{array}$

\section{1. 緒 言}

前報 ${ }^{1) 2}$ に引続き, 高周波曲げ加エによるエルボレス鋼管をプラント配管等へ適用する場合の検討項目 の一つとして，本報では曲げ部に偏肉を有するエルボレス鋼管の静的面内曲げ特性を明らかにした。

\section{2. 実験方法}

A S T M A 106 B クラスの強度を有する素管 $168.3 \phi \times 7.1 \mathrm{t}$ およひ $11.0 \mathrm{t}$ をちちいて, 曲率半径

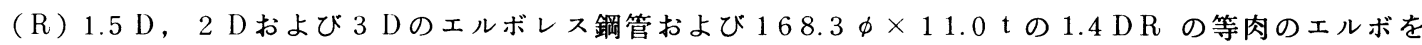
供試管とした。いずれも $90^{\circ}$ の曲げ角度を有する曲げ管である。一端はフランジによる固定で，他端の 自由端に油圧シリンダにより曲げ荷重を付加する方法で曲げ部に曲げモーメントを与え，二軸の歪ゲー ジにより外表面の応力測定を行った。

\section{3. 理 論}

偏肉を有する曲げ管の応力は, Kármán の第一次近似式 ${ }^{3}$ を搪張して求めた。偏肉各部の肉厚を図 1 亿示すように近似

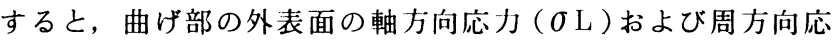
力 $(\sigma \mathrm{C})$ は下式により与えられる。Kármán 拡張式の特徵 は(1)係数 k.I. $\lambda$ には平均肉厚を用い,更に(2)偏肉 a を考慮し ている。

$$
\begin{aligned}
& \sigma L=\frac{K M R}{\mathrm{I}}\left\{\sin \phi-\frac{6}{5+6 \lambda^{2}} \sin ^{3} \phi+\frac{9 \nu \lambda}{5+6 \lambda^{2}}(1-a \sin \phi) \cos 2 \phi\right\} \\
& \sigma \mathrm{C}=\frac{\mathrm{KMR}}{\mathrm{I}}\left\{\nu\left(\sin \phi-\frac{6}{5+6 \lambda^{2}} \sin ^{3} \phi\right)+\frac{9 \lambda}{5+6 \lambda^{2}}(1-\mathrm{a} \sin \phi) \cos 2 \phi\right\} \\
& \text { ここで, } K=(\text { たわみ係数 })=\left(10+12 \lambda^{2}\right) /\left(1+12 \lambda^{2}\right) \\
& \mathrm{I}=(\text { 断面二次モーメント })=\pi\left(D^{4}-(D-2 \mathrm{tm})^{4}\right) / 64 \\
& \lambda=(\text { パイプ係数 })=\mathrm{R} \mathrm{tm} /(\mathrm{D}-\mathrm{tm})^{2}
\end{aligned}
$$

\section{4. 結 果}

(1) Kármánの式による計算値 $(\mathrm{a}=0)$ とエルボの実測 值はよく一致することが確認された（図２）。

(2) Kármánの拡張式による計算値とエルボレス鋼管の $\lambda=0.34 \sim 0.95$ の範囲の実測值はよく一致する（図 3 ) 特に最大灾力となる $\phi=0(\mathrm{~N})$ 近傍では偏肉の影響は殆 どなく，発生応力には平均肉厚のみを考虑すればよい。

(3) 以上の結果から, 外周部 (T) の隇肉があってもエルボ より平均肉厚の大きいエルボレス鋼管は, エルボと比較 して安全性が高いととが明らかになった。

1）賀川他鉄と鋼，73(1987)S 306

2）賀川他鉄と鋼，73(1987)S307

3) Th.V.Kármán "Uever die Formänderung dünwandiger Rohre , insbesondere federnder Ausgleichrohre", Z. VDI , 55(1911), 1889

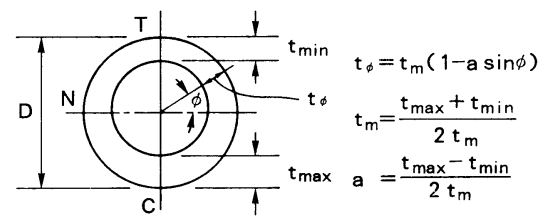

Fig. 1 Dimensions of Elbowless

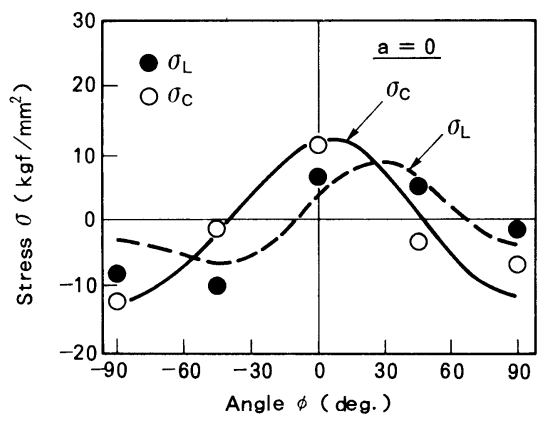

Fig. 2 Stress Distribution of Elbow with $168.3 \phi \times 11 \mathrm{t} \times 1.4 \mathrm{DR}$

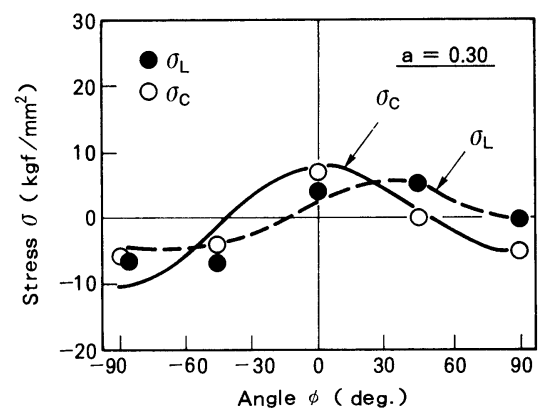

Fig. 3 Stress Distribution of Elbowless with $168.3 \phi \times 11 \mathrm{t} \times 1.5 \mathrm{DR}$ 


\section{1. 緒 言}

新日本製鐵侏 井上, 靖介O直井 久

前報に引き続き，高周波曲げ加工によるエルボレス鋼管をプラント配管等へ適用する場合の検討項目の $1 つ$ として，本報ではその配管設計基準を明らかにすへく面内曲げ及びそれに内圧が複合して加わった場合の 1)応力集中係数 i と2)たわみ係数 k について検討した。

\section{2. 実験方法}

成分は ASTMA106B相当品で $168 .^{{ }^{\phi}} \times 7.1^{\mathrm{t}}$ 及び $168 .^{{ }^{\phi}} \times 11^{\mathrm{t}}$ の 2 サイズ を素材とし，高周波曲げ加工によって曲げ半径 $\mathrm{R}=1.5,2.0,3.0 \mathrm{D}$ 製 造したエルボレス鋼管を用いた。更に比較材として成分は同一で $168 .^{{ }^{3}}$

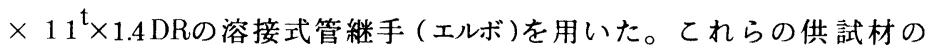
袖部に鏡板をつけ，管体の外表面にストレンゲージをはりつけた後， 管体に水により内圧を加えると同時に面内曲げを加え，管周方向の 歪を測定すると同時に管体の変位をダィヤルゲージで測定した。

\section{3. 実験結果及び解析}

1）エルボに面内曲げが単独で加わる場合の配管設計基準は, 米国 ANSI B31.3のCode等でパイプ係数 $\lambda=4 \mathrm{t} \mathrm{R} / \mathrm{D}_{\mathrm{m}}^{2}$ を変数として(1)，(2) 式で規定され，その理論的背景は Kármán 解析 ${ }^{1)}$ となっている。

応力集中係数 (面内曲げ) $\mathrm{i}=1.8 / \lambda^{2 / 3}$

たわみ係数 ( $" ） \mathrm{k}=1.65 / \lambda$

エルボレス鋼管の面内曲げ特性は前報からKármánの式の肉厚 $\mathrm{t}$ として, 平均肉厚を用いればよいてとから，パイプ係数も平均肉厚を用って i とk 整理した。その結果 Fig.1及び Fig. 2 亿示すようにェルボ と同様の特性を示した。

2) エルボに面内曲げとともに内圧が複合した場合は，内压による偏 平矯正効果があり, $\mathrm{i}$ と䐈は内压の增加とと屯に減少するてとが Kármán 等によって解析されている。その減少係数は压力係数 $\Psi=$ $1.82 \mathrm{PR}^{2} /\left(\mathrm{E} \mathrm{D}_{\mathrm{m}} \mathrm{t}\right)$ を変数として表わされ²), ANSIでCode化されてい る。エルボレス鋼管の $\mathrm{i} と \mathrm{k} へ$ へ内压が及ぼす影響について, 平 均肉厚を用いて検討したが, エルボと同様の特性を示した。（Fig.3 にたわみ係数 $\mathrm{k}$ への影響を示した）

\section{4. 結 論}

面内曲げとそれに内圧が加わった場合の特性はKármánの式で表わ され，ANSI Codeによる設計基準がエルボレス鋼管にも適用出来る 事を示した。

\section{<参考文献 $>$}

1) Von Kármán ; Z., V.D. I., Vol.55, (1911), P1889

2) 鵜戸口ら ; J HP I, Vol.6, №.3, (1968), P1328

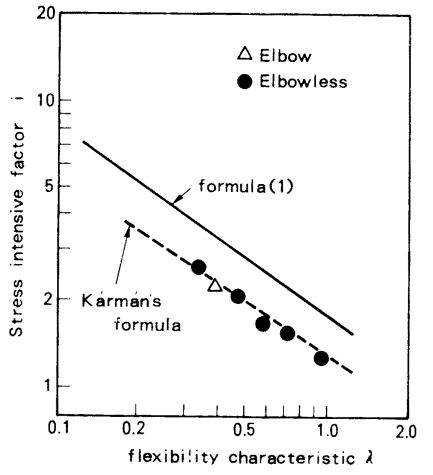

Fig. 1 Stress Intensive Factor at

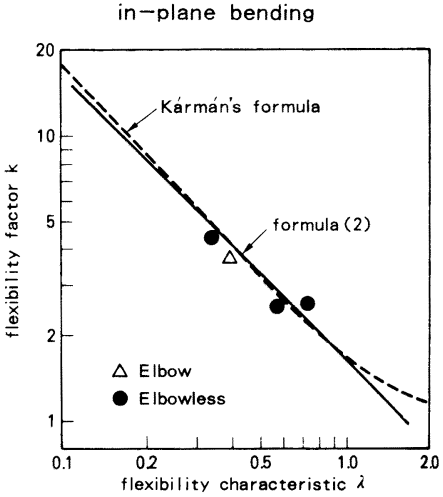

Fig. 2 Flexibility Factor at in-plane bending

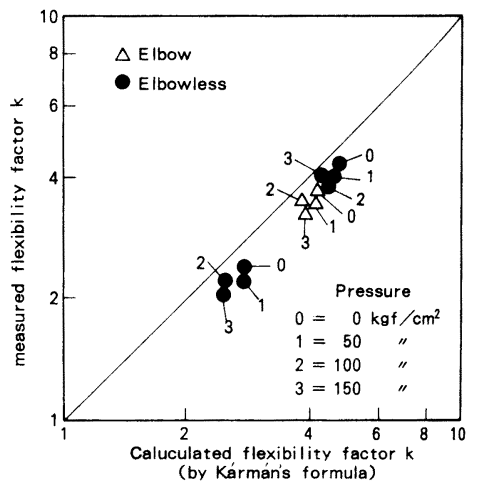

Fig. 3 Flexibility Factor at in-plane bending effected by internal pressure 


\section{（321）有限要素法による油井管継手リーク判定方法 - 油井管継手の金属対金属シール機構に関する研究 (2) -}

新日本製鐵 八幡技術研究部 ○津留英司, 丸山和士 神山藤雅, 小笠原昌雄

\section{1. 緒言}

金属密封部を有する油井管特殊継手(ブレミアムジョイント(P. J.))のシール性評価のひとつに F EA (有限要素法)に よる金属密封部シール面圧解析がある。しかし従来, シール限界面圧が不明なため接触面圧が判ってもリーク判定は 困難であった。本報告では第 1 報 ${ }^{1)}$ と同椂なシール性評価テストによりガスシール限界面圧を求め, シール性が面圧積 分の概念を導入し整理できるととを示す。また，ての面圧積 分と F E A 結果を利用した継手シール評価法を提案した。

\section{2. リーク圧力之面圧積分の関係}

第 1 報 ${ }^{1)}$ に示した試験装置に Table 1 亿示すシール長さ $(\mathrm{t})$ のサンプルを使用し,陚験面からのリーク圧力 $\mathrm{P}_{\mathrm{L}}$ 在測定した。 Fig.1に $P_{\mathrm{L}}$ と面圧積分（pec）の関係を示す。ここに

$$
\text { pec }=\frac{\mathrm{W}_{\mathrm{L}}}{\pi(100-\mathrm{t}) \cdot \mathrm{t}} \cdot \mathrm{t}=\frac{\mathrm{W}_{\mathrm{L}}}{\pi(100-\mathrm{t})}
$$

$\mathrm{W}_{\mathrm{L}} ;$ リーク発生時の荷重

$\mathrm{P}_{\mathrm{L}}$ と pecはシール長さにかかわらず, 同様な比例傾向を示 し， $P_{L}$ は pecによって支配されることがわかる。

\section{3. 面圧積分理論に基づく継手シール性評価法}

Fig.2 亿 FEAに用いた継手 A (点接触型)と継手B（線接 触型) の金属密封部及びギャップ要素位置を示す。上記 pec に対し, P.J.金属密封部には負荷相当面圧積分 (pea) が存 在し, peaは接触面圧の積分值を意味する。したがってF E A から peaは次式となる。

継手A 亿対し $\quad$ pe $a=\int_{0}^{\ell_{\mathrm{a}}} \mathrm{p}_{\mathrm{c}}(\ell) \mathrm{d} \ell=\frac{\mathrm{Wg}}{\pi \mathrm{d}}$

継手 B 亿対し

$$
\text { pea }=\int_{0}^{\ell_{\mathrm{b}}} \mathrm{p}_{\mathrm{c}}(\ell) \mathrm{d} \ell=\frac{\mathrm{Wg}_{1}}{\pi \mathrm{d}_{1}}+\frac{\mathrm{Wg}_{2}}{\pi \mathrm{d}_{2}}+\frac{\mathrm{Wg}_{3}}{\pi \mathrm{d}_{3}}+\frac{\mathrm{Wg}_{4}}{\pi \mathrm{d}_{4}}
$$

$$
\mathrm{p}_{\mathrm{c}}(\ell) \text {; 面圧分布 } \ell_{\mathrm{a}}, \ell_{\mathrm{b}} \text {; シール長さ }
$$

$\mathrm{W}, \mathrm{Wg}_{1} \sim \mathrm{Wg}_{4}$; ギャップ要素反力 $\mathrm{d}, \mathrm{d}_{1} \sim \mathrm{d}_{4}$; シール径 シール性評価は pec と peaの比較より得られ, pec=peaがシール限 界を表わす。FEAで求めた継手モデルの締込み時, 引張荷重負荷時, 内圧角荷時の pea挙動をFig.3 亿示す。乙の例では peaは Fig.1から 得られる pecより常に大きく種々荷重条件下でシール性が確保でき ることを意味している。

\section{4. 結言}

シミュレーション実験から得られる面圧積分, pecと FEAから得 られる面圧積分, pea 比較することで種々荷重条件下の解析的シ 一ル性評価が可能となった。
荟考
1）日本鉄鋼協会第 112 回講演大会 (346)

Table 1. Specimen Conditions

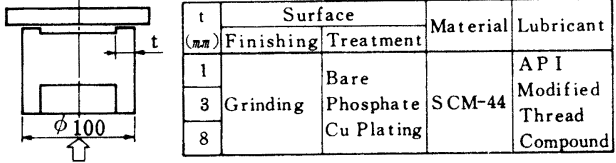

Compressive Load:W

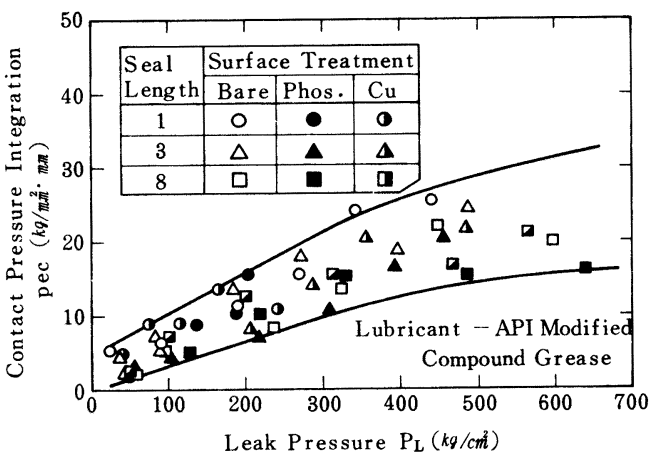

Fig. 1 Relationship between Leak Pressure and Contact Pressure Integration

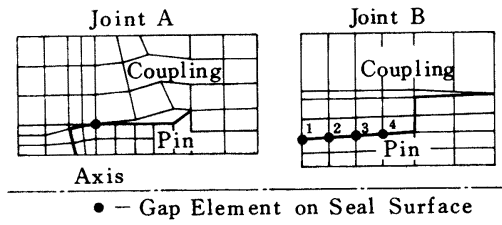

Fig. 2 Seal Portion Model by FEA

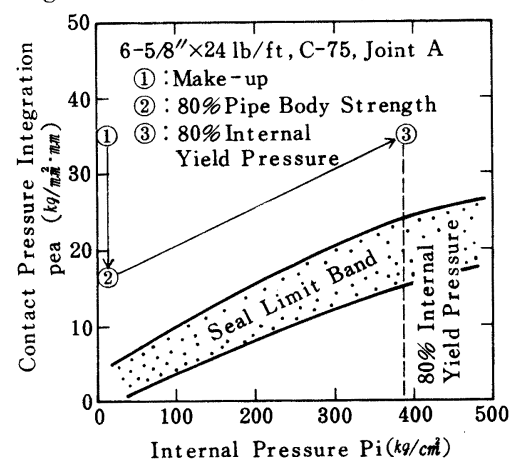

Fig.3 Leak Judgement Diagram 


\section{1. 緒 言}

ツールショョイントのシール特性は, Wash-out 防止の観点から重要である。周知のようにツールジョイントのシー ルは, Make-and-Break Shoulder 部で行われており, シール性能は, Make一upにより生ずる接触面任に依存す る。したがって，母管耐力に対応するシール限界Make-up トルクが存在するはずであるが，てれらは，今のとてろ 明確でない。そこで, 本報ではツールジョイントのシール限界 Make-upトルクについて解析的および実験的に検討する。

\section{FEMによるシール限界Make - upトルクの検討}

Table 1 に対象材のサイズおよびグレードを,Fig. 1 には

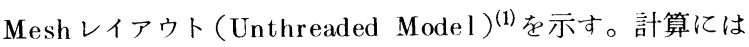
MARC FEM プログラムを使用し, 弾塑性解析を行った。 Make-upトルクはAPI 推奖値とし, 軸方向引張を外部荷重 とした。Fig.2亿解析により得られたShoulder 部の接触力 と軸方向引張力の関係を示す。接触力が 0 になったとさり ークが発生するとすれば, 対象材は 574 tonの引張荷重まで Table 1 Size and Grade of Drill Pipe used in FEM

\begin{tabular}{|l|l|}
\hline $\begin{array}{l}\text { Tool } \\
\text { Joint }\end{array}$ & $\begin{array}{l}5-1 / 2^{\prime \prime} \text { F H } 7-1 / 2^{\prime \prime}\left(\mathrm{O} . \mathrm{D} . \times 3-1 / 4^{\prime \prime} \mathrm{I} . \mathrm{D} .\right. \\
(\text { Recomended Make-up Torque }: 5500 \mathrm{k} q \mathrm{f}-m)\end{array}$ \\
\hline $\begin{array}{l}\text { Pipe } \\
\text { Body }\end{array}$ & $\begin{array}{l}\text { G }-105,5-1 / 2^{\prime \prime} \mathrm{O} . \mathrm{D} . \times 0.8^{\prime \prime} \mathrm{T} \\
\text { ( SMYS }=560 \text { ton })\end{array}$ \\
\hline
\end{tabular}

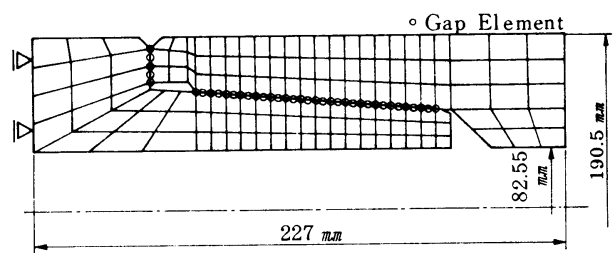

Fig.1 Mesh Lay-out used in FEM シール性を維持する。一方, シール限界Make一 - up ルクの定義を母管耐力荷重下でシール性在維持する 最小トルクとすると, 対象材のそれは, Table 2 よ り $4569 \mathrm{kgf}-\mathrm{m}$ となる。

\section{3. シール限界Make-upトルクの簡便計算法}

Table 2 における切片と傾き，すなわち, Make一 $\mathrm{up}$ 時の接触力 $\mathrm{P}_{\mathrm{M}}$ と軸力に対する $\mathrm{P}_{\mathrm{M}}$ の减少率 $\phi$ を机 上で算出するととができれば煩雑な FEMにならなく ともシール限界Make-up トルクを求めることがで

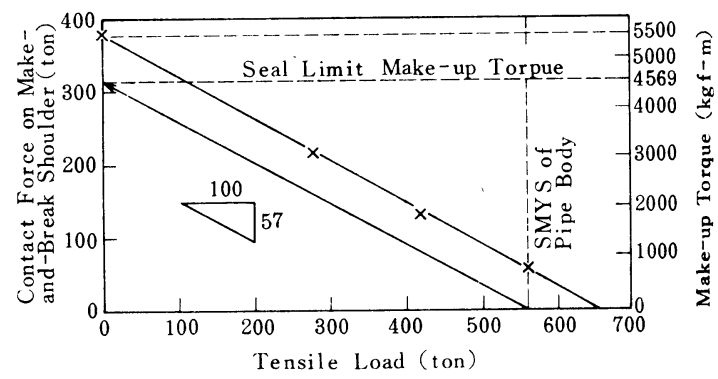

Fig. 2 Relationship between Contact Force and Tensile きる。ここでは(1)(2)式で $\mathrm{P}_{\mathrm{M}}, \phi$ を算出し, シール限 界Make一upトルクを求めた。Table 2 亿示すようにFEMの結果と良 く一致する。

$$
\begin{aligned}
& \mathrm{P}_{\mathrm{M}}=12 \mathrm{~T} /\left(\mathrm{p} / 2 \pi+\mathrm{R}_{\mathrm{t}} \mathrm{f} / \cos \theta+\mathrm{R}_{\mathrm{S}} \mathrm{f}\right) \\
& \phi=\mathbf{A}_{\mathrm{B}} /\left(\mathrm{A}_{\mathrm{P}}+\mathrm{A}_{\mathrm{B}}\right)
\end{aligned}
$$

ここで $A_{P},\left(A_{B}\right)$; Shoulder から $19.05 m m$ 位置のP in (Box) の平均断面積 またFig.3は，他サイズに対し本計算法を適用し実験と比較した結 果を示す。両者は比較的良く一致している。

\section{参考文献}

(1) W.T.Asbill, et al.: Trans . ASME Vol. 106, Mar. 1984, pp. $130-136$.

(2) API RP7G pp. 90.
Table 2 Comparison between presented Method Results and FEM Results ( $k g-m)$

\begin{tabular}{|c|r|}
\hline Presented Method & FEM \\
\hline 4479 & 4569 \\
\hline
\end{tabular}

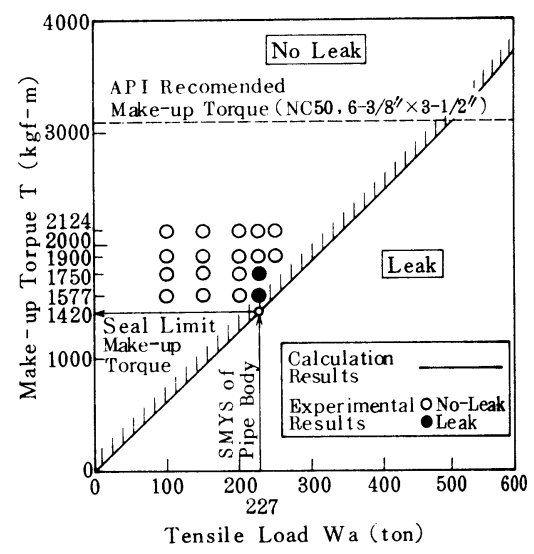

Fig. 3 Comparison between Calculation Results and Gas Leak Test Results (NC 50, 6-3/8"O.D. $\times 3-1 / 2^{\prime \prime}$ I.D. X-95, 5" $\times 19.50$ \# 


\section{1. 緒 言}

新日鐵名古屋では油井管精整作業の省力化を図るべくロボットを用いた自動化技術の開発に取り組ん でをた。その中で今回㳩用口ボっトと自製開発による専用のエンドエフェクターとを組み合わせた，カ ップリング装着ロボットの㫪用化を完了したので以下にその概要を報告する。

\section{2. 鋼管カップリング装着ロボット}

第1図に今回のカップリング装着ロボットおよび周辺システムの概要を示す。使用したロボットは 6 軸垂直多関節型の沉用口ボットで $120 \mathrm{Kg} の$ 可搬重量を有する。このロボットの手先に今回開発した装 着用エンドエフェクターを接続しカップリングの装着作業を行なら。なおパイプネジおよびカップリン グネジ面へのグリース塗布についても従来人手に賴っていたのを装着ロボットの設置に合わせ今回自動 塗布装置を新設し, 一連の作業の完全自動化を図っている。

フィーダーに插入されたカップリングは自動で斜面を転がり, 途中グリサーで内面にグリースを塗布 された後ワーク供給装置まで送られる。一方パイプの方もネジ面にグリースが塗布された後ロボット前 面のターニングローラまで般送され押えローラにてセットされる。ての押えローラはパイプターニング 時の面振れを抑制するはたらをを持っている。ワーク供給装置にセットされたカップリングをロボット がつかみネジ込み位置（パイプ端面）まで移動し，エンドェフェクターに内蔵した小型モータでカップ リングを回転させ $2 \sim 3$ 山程度のネジ山合わせを行なった後パイプをターニングしネジ込みを開始する。

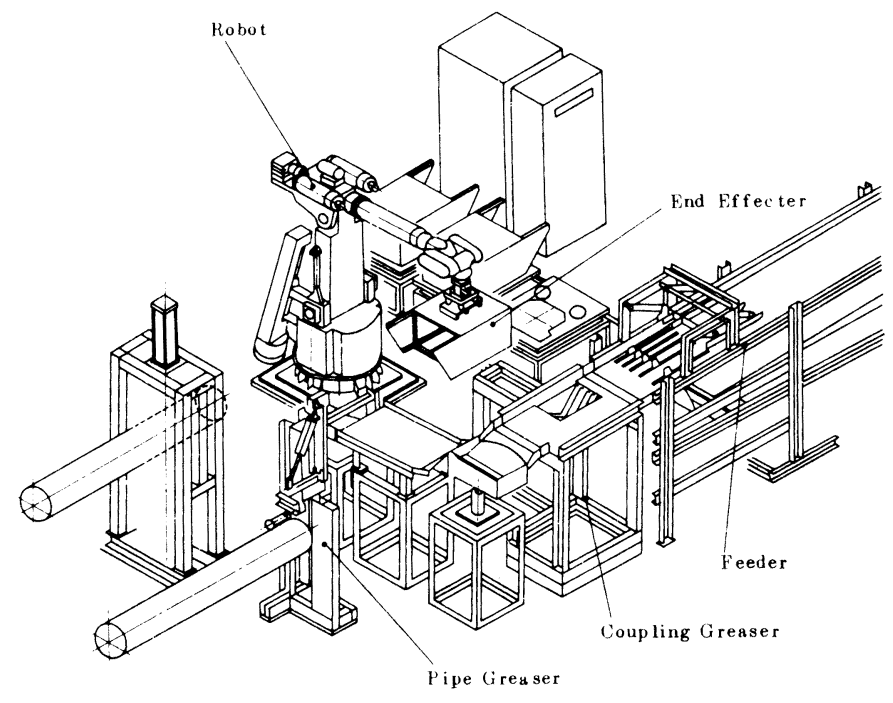
設定したネジ込みトルクに達するとカッ プリングがパイプと共回りし始め，乙の とをエンドエフェクターのつめを開いて 装着作業が終了する。

今回開発したエンドエフェクターの特 徵としては(1)柔構造の採用とネジ山合わ 世機構によりネジ面を伤付けない。(2)多 数の検出器を内蔵し，てれらによって正 常にネジ込まれているかどうかを自己監 視し, 否の場合は位置データ, 速度等を 補正しながら確実にネジ込み作業を完了 する。(3)カップリングのサイズ別に 3 種 類のエンドェフェクターを用意し段取替 え作業を簡略化するためマスターハンド 方式とした，等がある。

Fig. 1 Schematic view of a pipe coupling pre-tightening robot

\section{3. 結 言}

本口ボットは昭和62年 3 月据付完了し, 以後改良を加えながら実操業稼動中である。ネジのかみ込み 等品質上の問題も無く，タイムサイクルについても1本あたり70〜80秒と従来の人手作業の場合と同レ ベルの速さで処理しており, 精整作業の省力化, 自動化に寄与している。 


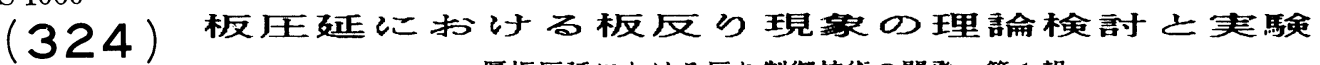
一厚板圧延における反り制御技術の開発 第 1 報一

川崎製鉄水島製鉄所 ○吉井 誠 大森和郎 瀬戸恒雄

西崎 宏 井上正敏

\section{1、緒言}

板圧延における鋼板反りの発生は，圧延能率の低下，品質劣化などの原因となるばかりでなく，時には設備破損に まで至ることもあり，反り制御技術の確立が望まれている。しかしながら，反りの発生が鋼板先端の非定常部で起こ るため定量的な解析が難しいこともあって，これまであまり解析されていないのが実状である。1 〜2) 本報ては，用 塑性有限要素法を用いたシミュレーションモデルおよび実機実呀から得られた反り発生機構に関する知見について報 告する。

\section{2. 解析モデル}

今回開発した剛塑性有限要素法は, 上下ロール回転数, 上 下摩摖係数，上下面温度をそれぞれ独立に取り报える鋼板先 端部の非定常解析手法である。計算では，鋼板を厚板方向に 8 分割, 長手方向は接触弧内を 16 分割したモデルを用い, 出 側上下面の速度差を用いて反り曲率を計算した。

\section{3. 解析結果书よび害馀結果}

Fig.2 に異速率を変化させた場合の $\mathrm{Ld} / \mathrm{hm}$ （接触弧長／平 均板厚）と反り曲率の関係を示す。図中の実駼結果は, 水島 厚板ミルで圧延中の鋼板先端部の写真撮影を行って反り曲率 を求めたものである。これから反りに対する異速率の影䜿は $\mathrm{d} / \mathrm{hm}$ で変化しており，Ld/hm=1.5 付近で反りの方向が逆転 することがわかる。この傾向は解析結果, 実駼結果とも一致 レており，本シミュレーションモデルによって反り現象の定 量化が可能と考えられる。

Fig. 3,Fig.4 に上下摩摖保数差, 上下面温度差を変化させ た場合の反り曲率の解析結果を示す。この場合もそれぞれが 反りに及ぼす影䪪は Ld/hmで変化していることがわかる。

\section{4. 結言}

板圧延における反り発生現象を解明するための剛塑性有限 要素法によるシミェレーションモデルを開発し、これを用い た解析および実験結果から，鋼板反りに及ほすす異速率，上下 摩摖係数差, 上下面温度差の影䪪をしd $/ \mathrm{hm}$ をパラメータとす ることによって定量化することができた。 <参考文献>

1) 中島ら: 昭和 57 年度塑性加工春季講演会 $P 65 \cong$ 2 ) 本村ら：第25回塑性加工連合講演会 P165

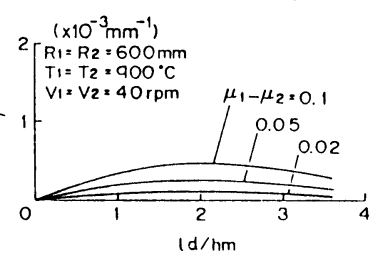

Fig.3 Effect of difference between $\mu_{1}$ and $\mu_{2}$ on plate curvature

$$
\begin{array}{ll}
V_{1}: \text { Upper roll speed } & V_{2}: \text { Lower roll speed } \\
T_{1}: \text { Upper surface temperature } & T_{2}: \text { Lower surface temperature } \\
\mu_{1}: \text { Upper coefficient of friction } \mu_{2} \text { : Lower coefficient of friction }
\end{array}
$$
Fig. 1 Finite element model

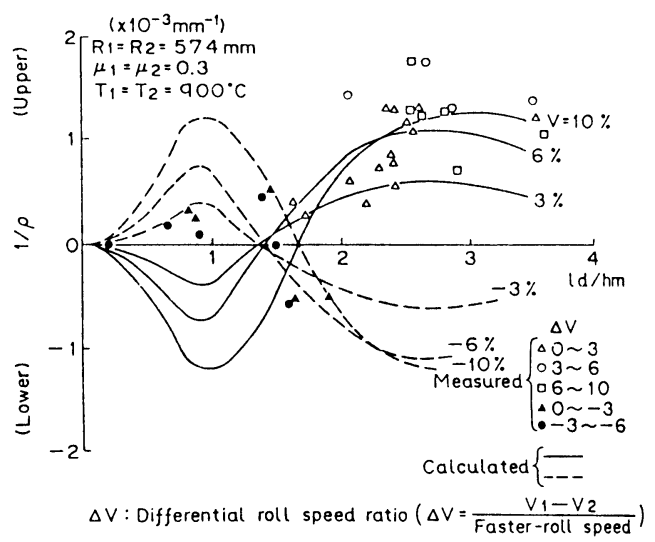

Fig.2 Effect of differential roll speed ratio on plate curvature

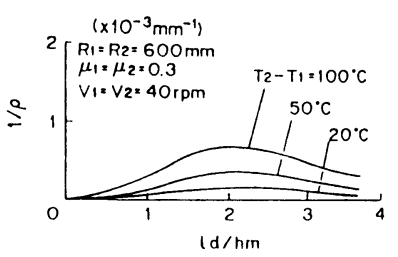

Fig. 4 Effect of difference between $T_{1}$ and $T_{2}$ on plate curvature 
1. 緒 言

昭和 61 年 9 月、大分製鐵所厚板工場に設真したエッジャーとエッジミラーは、順落に立ち上ク、幅精 度の向上、耳切代の低減に大きく貢献している。 ${ }^{1) 2)}$

本報では、エッジャ一とエッジミラーの組み合せによる幅入代の低減について報告する。

2. エッシ̈ャーによる圧延幅精度向上

エッジャ一の使用タイミングは、幅出し压延中及び仕上げ 压延中とし、エッジング量決定の考元方は、幅出し完了時の 压延幅偏差に応じ、仕上げ圧延中のエッジング量を決定し、 仕上げ圧延中のエッジングによる先後端部幅すぼみを補僋す ベく、幅出した延中のエッジング量を決定している。またエッ ジングパス回数については、仕上ミル近接型エッジャ一の利 点を活かし、仕上ミル币延のパス回数が增加しない範囲で決 定し压延能率低下を防いでいる。Fig. 1亿エッジングスケジ ュールの例を、Fig. 2 亿圧延幅精度向上の例を示す。

また、エッジャ一の効果により、従来必須とされていた形 状楛整圧延（含形状修正压延）を原則として省略し、压延 幅精度を向上しつつ能率向上を指向している。また、幅出比 とスラブ厚によって、選扒的に形状調整压延を追加すれば、 形状修正压延の訤果で、仕上压延中のエッジングによる幅す ぼみを軽減する事も可能である。

3. エッジャーとエッジミラーの組み合せによる幅入代低隇 エッジャーによって压延幅精度の画期的な向上が実現され た事によク、エッジミラーとの組み合せで、幅入代の大幅な 縮小が可能となった。エッジャーとエッジミラーの稼動前後 での幅入代の低減例をFig. 3 亿示す。

\section{4. 結 言}

仕上ミル近接型エッジャーのフル活用と、エッジミラー切 削との組み合せ効果により、大幅な幅入代の低減が実現し、 歩留向上に大きく貢献する事ができた。

\section{( 参考文献 )}

1）河野ら；鉄と銅 72(1986) S 1119

2）河野ら；鉄と鋼 73(1987) S 313

3）笹治ら；鉄と銅 67(1981)15，P2395-2404

4）渡辺 ; 塑性と加工 Vol 25 No277(1984-2) P75-80

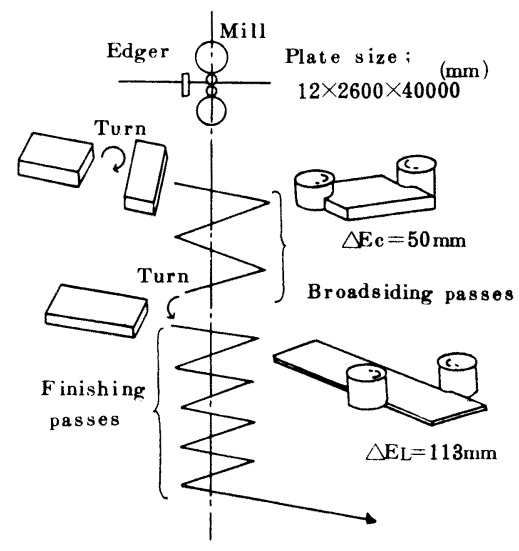

$\Delta E c$; Total edging value of Broadsiding passes $\triangle E_{L}$; Total edging value of Finishing passes

Fig. 1 Optimum Edging

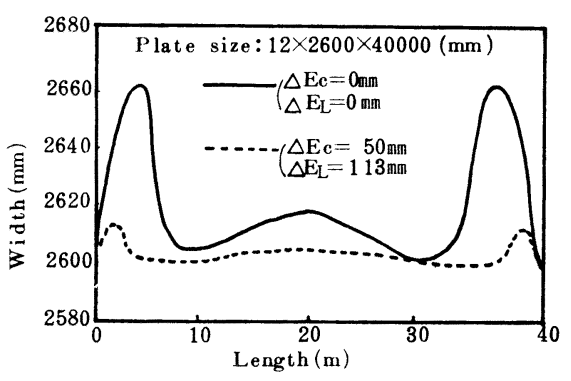

Fig. 2 Effect of optimum edging schedule on width

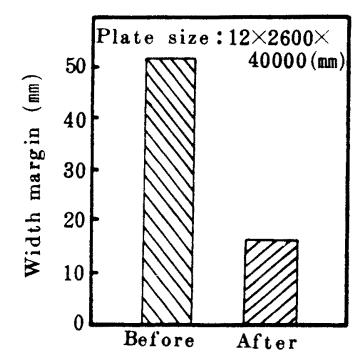

Fig. 3 Width margin saving by edger and edge-miller 


\section{1. 緒 言}

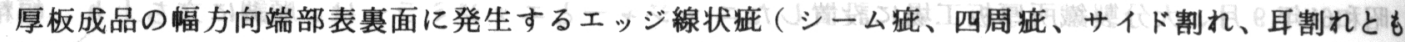
(う) は古くからの未解決の課題であるが、圧延幅精度及び幅切断精度を向上させて耳切代を削減し高 歩留化を図るにあたっては不可避の問題である。そこでその発生メカニズムを解明するために、実圧延 を通して調査・テストを行なった。

2. 調查・テスト方法

（1）圧延過程のいかなる板厚（圧延厚）の時にエッジ線状疵が発生するかを調査するために、压延を Table 1 亿示す圧延厚で途中中止し、放冷後、㾟の発生状況を調査した。

(2) (1)で調査したエッジ線状疵が発生しはじめる板厚の前後の板厚を同一スラブ内で造り出し（赖み 止め压延実施)その板厚移行部をミクロに調査した。そのテスト条件をTable 2 に示す。

\section{3. 結 果}

3. 1 エッジ線状疵発生板厚 Fig.1及びFig. 2 に発生したエッジ 線状疵の鏩板端面加らの発生位置、 疵深さと板厚との関係を示すが本圧 延条件では、板厚 $70 \mathrm{~mm}$ 未満の板厚て エッジ線状疪が発生した。

従って以降の揀み止め圧延テストに おいては $\mathrm{t}_{1}=80 \mathrm{~mm} 、 \mathrm{t}_{2}=40 \mathrm{~mm}$ とし て圧延した。

3.2 エッジ線状症発生メカニズムの推定 Fig.3 に咪み止め圧延後の板厚移行 部の各断面の写真を示す。 エッジ線状疵はこの図が示すように、 圧延厚の厚い仕上圧延初期の段階の 幅拡がり時、板厚表層部は板厚中心 部に比べロールによる固着や温度差 により幅拡がり量が小さいために側

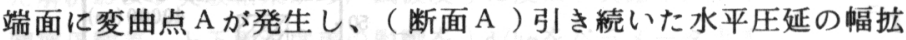
がりにより変曲点を含む側面部が表裏面へ迴り込み（断面 B，C） さらなる水平圧延により変曲点がオーバーラップし、疵 S として 表裏面上に残る（断面 D）ととにより発生するものと思われる。 4. まとめ

実圧延テストにより古くからの課題であったエッジ線状症の発 生メカニズムを解明するととができた。

\begin{tabular}{|c|c|}
\hline Ste6l & $\mathrm{Si}-\mathrm{Mn} 50 \mathrm{~K}$ \\
\hline Slab size & $\begin{array}{r}245 \times 1900 \times 2700 \\
(A s \text { cast })\end{array}$ \\
\hline Reheat ing temp. & $1150^{\circ} \mathrm{C}$ \\
\hline Rolling method & Straight \\
\hline Thickness of plate & $\begin{array}{l}150,120,100,70, \\
40,25,15,9 \mathrm{~mm}\end{array}$ \\
\hline
\end{tabular}

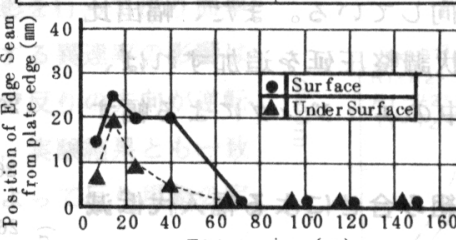

Fig. 1 Position of Edge Seam from plate edge

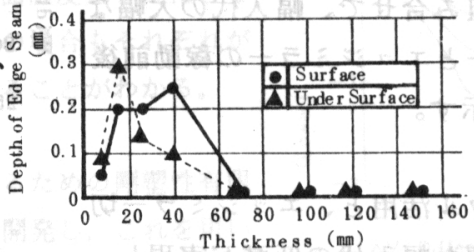

Fig. 2 Depth of Edge Seam
Table 1 Test condition (1)
Table 2 Test condition (2)

\begin{tabular}{|l|c|}
\hline Steel & Si-Mn 50 K \\
\hline Slab size & $245 \times 190 \times 2700$ \\
$(\mathrm{As} \cdot \mathrm{cast})$ \\
\hline Reheating temp. & $1150 \mathrm{C}$ \\
\hline $\begin{array}{l}\text { Dimension of } \\
\text { plate }\end{array}$ & $\mathrm{t} / \mathrm{t}_{2} \times 1900 \times \mathrm{C}_{1} / \mathrm{C}_{2}$ \\
\hline
\end{tabular}

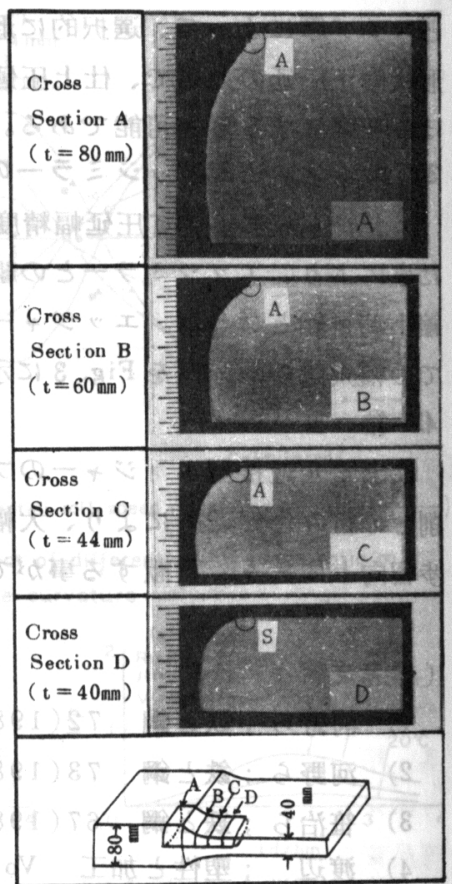

Fig. 3 Photograph of C ross Section 


\section{(327)}

板 圧 延 のキャンバー制御

(キャンバー形状測定モデルの現場確性)

新日本製鐵(株)大分製鐵所 $\bigcirc$ 中野鉄也, 大力 修, 間㴊秀里

第三技術研究所山田健二, 浜渦修一, 川並高雄

\section{1. 緒 言}

キャンバー制御精度の向上を为る手段として、圧延中のキャンバー形状を測定し、その結果を用いて 制御を行う方法がある。てれに関して、著者らは圧延中の板のキャンバー形状を実時間で測定するてと が可能なモデルを提案している。さらに、鉛材を用いたラボ害験により、本モデルがキャンバー制御精 度の向上を四る上で、有効であることを確認した。本報告では、このキャンバー形状測定モデルに基づ いて、大分・厚板工場に於て行った実機による工場実験結果について報告する。

\section{2. キャンバー形状测定装置の概要}

本装置のシステム構成をFig. 1 亿示す。本装置は、仕上 げ压延機の後面に既設の光学式幅/長計を位置検出器とし て用いる、幅/長計の検出值は、マイクロプロセッサを通 じてキャンバー形状同定計算用 C P U に取り込まれる。

3. キャンバー形状の同定方法 キャンバー形状の同定は、Fig. 2 に示す手順で行う。

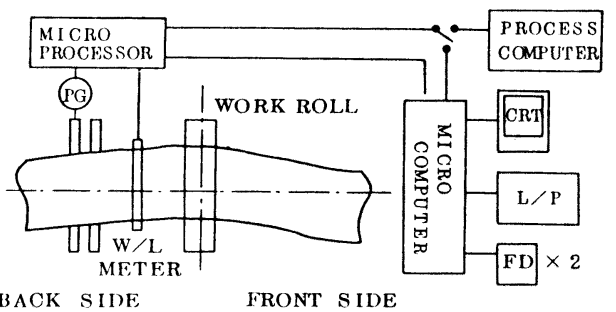
BACK SIDE

Fig. 1 Measuring system

(1) 幅 / 長計を材料の入側位置娭出器として用いるために、BADK SIIDE FRONT SIDE 圧延スケジュールを前面什上げに特定する。

(2) 最終パスの直前に空パスを設け、初期形状を測定する。

(3) 最終パスでは、位置検出器の位置における材料のオフ センター量を測定する。

(4) 出側キャンバー形状の同定計算（オフライン）を行う。 なお、キャンバー形状の変化を同定する能力を確認する目

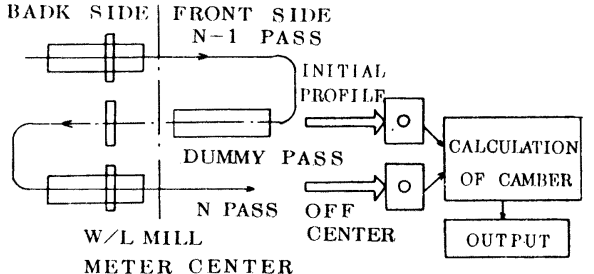

Fig. 2 Measuring method 的で、最終 1 パス前にてキャンバーを発生させ、最終パスで てれを修正するようにギャップ差を設定した。

\section{4. キャンバー同定結果}

本キャンバー形状測定モデルを用いて同定した 結果と圧延完了後、剪断ラインにて実測したキャ ンバー形状との比較をFig. 3 に示す。最終 1 パス 前のキャンバー形状（初期形状）と最終パスの任 延条件とから、最終のキャンバ一形状が同定され ている。

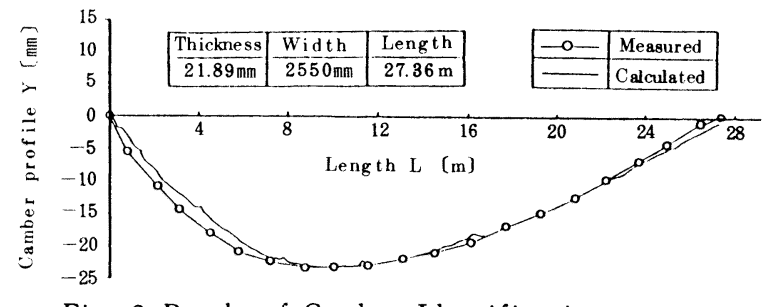

Fig. 3 Result of Camber Identification

\section{5. 結 言}

本キャンバー形状測定モデルが、実機においてもキャンバー形状の変化を同定することが可能である ことを確認した。今後は、制御モデルの開発を行う。なお、今回は計算機の演算速度ネックのため、出 側キャンバー形状の同定計算をオフラインで行ったが、原理的にはオンライン計算が可能であり、今回 の実験で行ったように、初期形状測定のために空パスを設ける必要はない。

\section{菱考文献}

1) 浜渦他：塑加工連講（S60) №.143 2 $)$ 浜渦他：塑加工連講（S60) №.144 
(328) Stress Analysis of Plate during Accelerated Cooling

$$
\text { H.Y.Kim, W.Y.Choo }
$$

Research Institute of Industrial Science and Technology, KOREA

1. Introduction

One of the important considerations in applying Accelerated Cooling (ACC) process is the flatness control of a plate. Nonflatness of the plate is attributed to the excessive thermal stress, caused by the nonuniform temperature distribution during ACC process. In this study, thermal stress analysis model was developed and the wave-type plate distortion was analyzed.

\section{Modeling}

The thermal stress analysis model was formulated under the following assumptions;

i) The wave-type plate distortion depends on the longitudinal stress only.

ii) Temperature distribution in the through-thickness direction is not considered, but the mean temperature is used.

iii) Compatibility condition is that a plane, orthogonal to the rolling direction, remains a plane orthogonal to that direction.

In the model, the stress state was analyzed using the temperature-dependent mechanical properties of materials and the volume-change during phase transformation was expressed as the effective thermal expansion coefficient.

\section{Results}

The actual temperature history of $10 \mathrm{~mm}(\mathrm{t}) * 3000 \mathrm{~mm}(\mathrm{w})$ size plate was measured by $\mathrm{K}-\mathrm{type}$ thermocouples. For convenience, simplified temperature history shown in Fig.l was used in thermal stress calculation. Thermal stress calculation results are shown in Fig.2. In certain temperature range, thermal stress was equal to the yield strength $\left(\sigma / \sigma_{\mathrm{Y}}= \pm 1\right)$. This means plastic deformation or plate distortion occurred.

The residual stress was measured through the Holedrilling method and compared with the calculated value. There was a good correlation between these two values.

This thermal stress analysis model was found to successfully predict the deformation behavior during ACC process.

4. Reference

1) A.Mendelson, PLASTICITY; theory and application, The Macmillan Co., 1968

2) Calculation of Internal Stresses in Heat Treatment of Metallic Materials, Sympo. Univ. of Linköing, May 1984

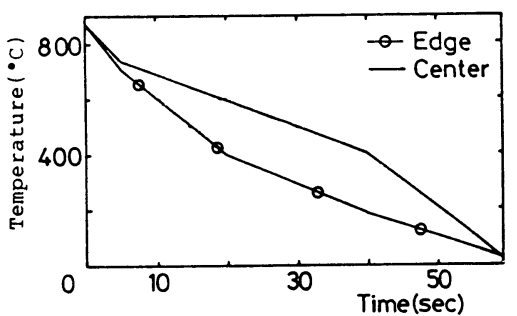

Fig.l Typical temperature history at edge and center in plate.

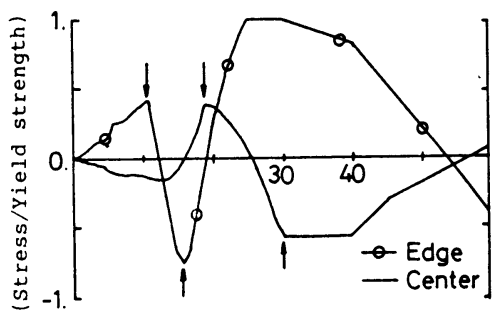

Fig.2 Results of thermal stress analysis.

।: Transformation start.

f : Transformation end. 


新日本製鐵(侏) 名古屋技術研究部 $\bigcirc$ 的場 哲, 阿高 松男
名古屋製鐵所 堀部 晃, 浅田 雅文

1.はじめに

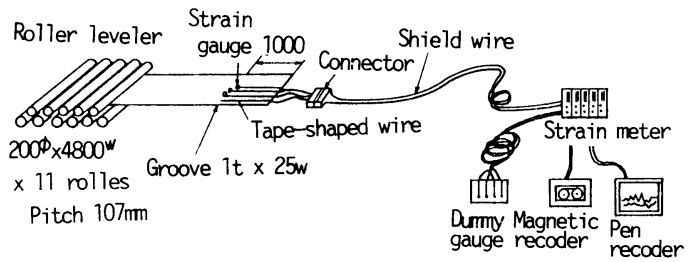

硬質で残留応力が大きい厚板をローラレベラ矯正す るには，十分に大きい曲げ歪を与える必要があるが， 矯正反力によるロールのたわみを考虑した条件にしな いと, 条切り後の板反りなどの問題を引き起こす ${ }^{1)}$ 。 gauge recoder Pen recoder 本報告では, 矯正曲率の幅位置での変化を実測し, 矯 Fig. 1. Mesurement of strain during roller leveling.

正反力との関係を求めようと試みた。

\section{2. 実匰方法}

矯正歪は, Fig.1の方法で求めた。板幅位置での歪 の違いは, 幅の片側 4 ケ所で測定した。歪ゲージは深 さ $1 \mathrm{~mm}$ の溝底に貼った。F ig. 2 に歪の測定例を示す。 矯正反力はレベラの八ウジングボストの歪から求めた。

矯正曲率はローラレベリング中の膜歪が無視できる として板片面の歪のみから計算した。以下, 曲率 K は 降伏曲率 $\mathrm{Ke}\left(=2 \sigma_{\mathrm{e}} / \mathrm{tE}\right) ， \sigma_{\mathrm{e}}$ : 降伏点, $\mathrm{t}$ ：板厚， $\mathrm{E}$ ：弾性定数）で無次元化して $\mathrm{K} / \mathrm{Ke}$ で示す。

\section{3. 実験結果およひ考察}

Fig.3 は, 矯正条件を強くした時と軽くした時の曲 率 $\mathrm{K} / \mathrm{Ke}$ と板幅位置の関係を示した。矯正能力を上げ ようとして強圧下すると, 板端のみが強く曲げられて 板中心付近との曲率差が大きくなり, 却って, 幅位置 での残留応力の不均一などの不都合を招くことがわか る。Fig.4 には, 矯正反力を一定として, 幅方向の分 割バックアップロール位置を変化させるクラウン調整 機能を使った時の曲率変化を示す。乙の例では, クラ ウン調整が過剩な例となっている。つまり，矯正反力 に応じたクラウン調整が必要である。

矯正曲率が既知な場合，曲率から曲げモーメントが 計算でき，モーメントとロールピッチとの関係で反力 が計算できる。この計算と実測の矯正反力が一致する ので（Fig.5），本実験の信頼性は高いといえる。

\section{4.むすひ}

今後, ロールのたわみを曲率の幅変化から推定し, 適正矯正条件を検討する。

【参考文献】1)益居健ほ加：S61 春塑加講(1986)，331
$14.5 \mathrm{t} \times 3500 \mathrm{w}, \sigma_{e}=37 \mathrm{kgf} / \mathrm{mm}^{2}$ Leveling load: P=870 tf Crown adjustment : $C R=0 \mathrm{~mm}$

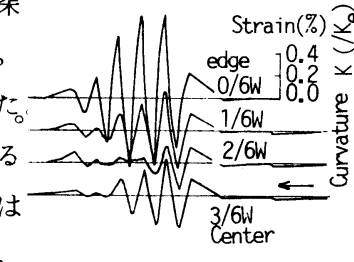
leveling strain.
Fig.2. Example of observed

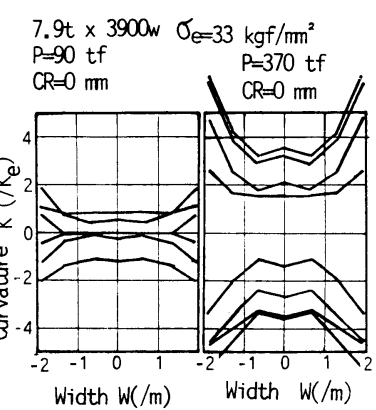

Fig. 3. Lateral distribution of curvature according to difference in leveling load.

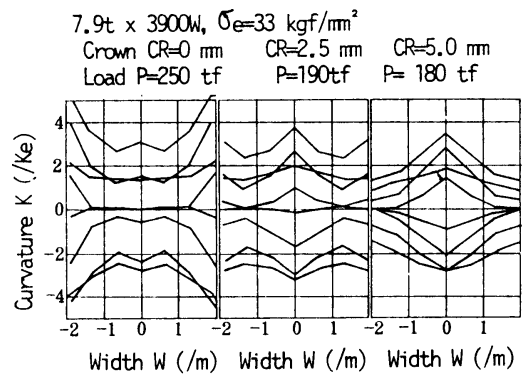

Fig.4. Changes in curvature according to crown adjustment.

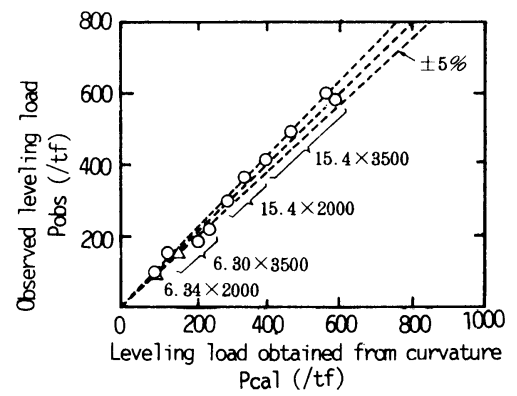

Fig.5. Comparison of calculated leveling load obtaind from curvature and observed leveling load. 
（330）厚板スラブャードの自動化システム

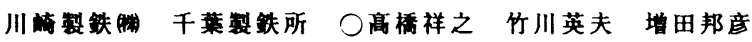

戸来光義森淮 日高貢成

1. 緒 言

千莱铁所厚板工場では、省エネルギー、品筫向上

省力を目的として加熟妒 "、スラブヤードのリフレッ シュを行ってきたか、今回スラブヤードの自動化シス テムを開発したのて、その概要を報告する。

2. スラブヤードの物流

工場レイアウトをFig. 1 に示す。制銿工場から貨車 にて発送されたスラブは、自動クレーンで受入れされ、 加熟妒装入命令が決定したタイミングで、ローディン テーブルから払出しされる。要精整スラブは精整ヤー ドで精整処理後、マッチングゾーンを中継地として、 自動ゾーンに山䊧みされる。

3. システム概要

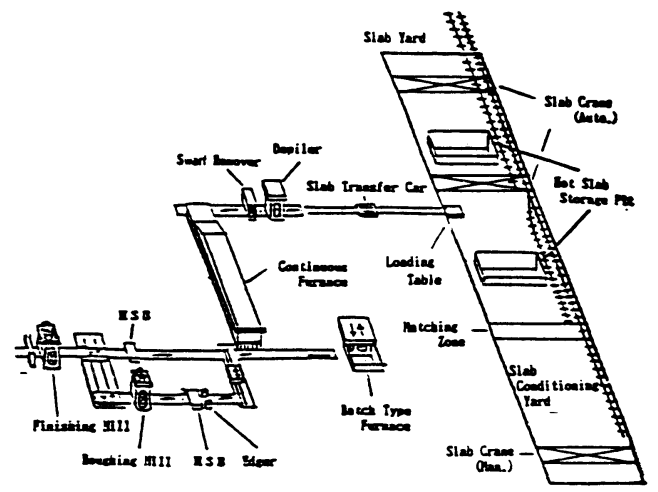

(1)制御システム構成

制御システム椿成をFig. 2 に示す。受入命令、払出命令、配替命令等 のスラブ报送命令は、O $/ \mathrm{C} て$ 作成後 $\mathrm{P} / \mathrm{C}$ に伝送される。 $\mathrm{P} / \mathrm{C}$ は命 令の実行順、および実行クレーンを決定し、クレーン、保熟ピットの自

動制御、スラブトラッキング、実绩伝送を行う。

(2)スラブ受入の自動化

貨車到着タイミングて、受入先置場决定、スラブ欵送命令作成が自動 で行われる。置場はスラブ同一属性単位の山樌みを目標として、ヤード 使用基华、寸法制限による山皘基準に従って決定される。スラブ匑送命

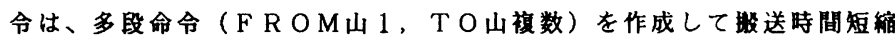
を計った。

(3)スラブ払出の自動化

会話型装入命令組にて払出順が決まると、加熟炉抽出ピッチに連動し て、払出時刻が計算され、払出命令が $\mathrm{P} / \mathrm{C}$ に伝送される。配替付きの 払出命令, 加熱妒重ね装入材の払出も可能とした。

(4)スラプ I D

スラブ重量、スラブ巾、山㮴高さ、クレーン国み厚、吊り枚数を計测 して、異材を自動湌出する機能をもたせた。

4.スラブ㒈送時間

1 命令の媄送所要時間は約 200 秒である。また貨車 1 蝙成の受入時間 をFig. 3 に示すか、機上運転とほほ同じレベルである。

5. 結 言

スラブヤート自動化システムの開発により、クレーン機上運転，玉持の 省力, H C R 温度向上に寄与している。

〈参考文嗝〉1)竹嶋 他: 鉄と铜 72 (1986)S1181

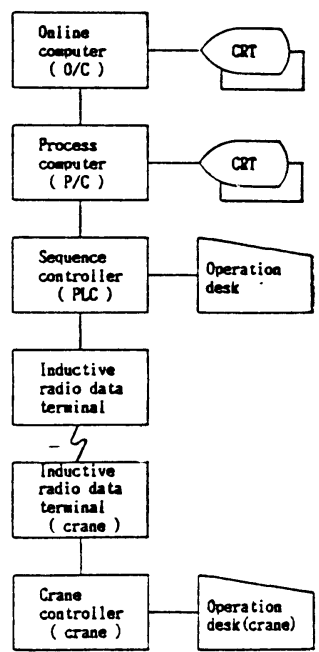

Fig.2 Configuration of control systen

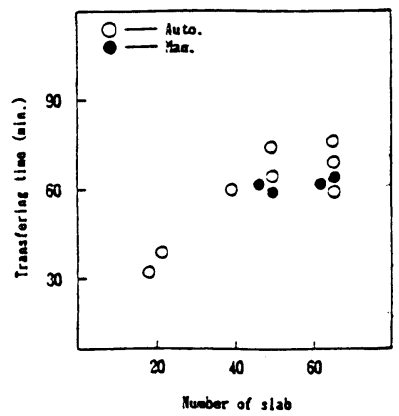

Pig.3 Lot slab transfering tim 


\section{（331）厚板工場自動ステンシル装置の設備と操業}

'87- S 1067

\begin{tabular}{|c|c|c|c|}
\hline 住友金属工業桻 & 鹿島製鉄所 & 亀山正利 & 加藤 信之 \\
\hline 全制御 & & $\begin{array}{l}\text { 斎藤修 } \\
\text { 大塚政信 }\end{array}$ & \\
\hline
\end{tabular}

I . 緒言

鹿島製鉄所厚板工場では, ショットブラィマーラインに業界初のドットスブレイ方式の自動ステ ンシル装置を設置し, ステンシル作業の無人化がはかられ, さらに鮮明な印字処理が可能となっ た。以下にその概 要を報告する。

II ・自動ステンシル装置の概要

Fig. 1 にショットブライマーラインのレイアウトを示 す。本装置は, ブライマ一叙装, 乾燥後の鋼板の所定 位置にステンシルを自動で行う。主を仕様は, Table 1 に示す。本体は, 駆動装置と印字機からなる。

1. 駆動装置

$\mathrm{X}, \mathrm{Y}, \mathrm{Z}$, の 3 軸と印字へッド 90 度反転用の副軸を持 った, ガントリ一型であり, 停止精度は, 土0.5 mmで ある。除塵, 給油の自動機能を持ち, メインテナンス が非常に容易である。

2. 印字機

ペンシルガンは, 球形バルブの開閉により高圧のペイ ントを噴射し，印字スピードが㥛めて早い。また，ド ットも小さく文字も鮮明である。Fig. 3 に文字の一例 を示す。

3. システム

システム制御にはマイコンが利用され，上位ビジコン の情報や，トラッキング用検出機からの信号が処理さ れる。本体は, 下位の駆動制御装置にあらかじめ教示 されたブログラムに従い, 作動する。

III. 効果

自動化に伴い合わせて 8 名の省力を達成した。また， 処理時間子，大幅に短縮された。

N. 結言 本装置は, 61 年 9 月以来, 順調に稼動しており, プ ライマーラインの能率アップに寄与し, 美しい印字処 理が可能となった。

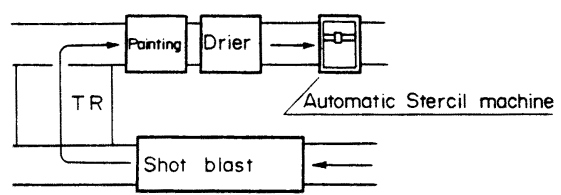

Fig.l Layout of Shot primer Line

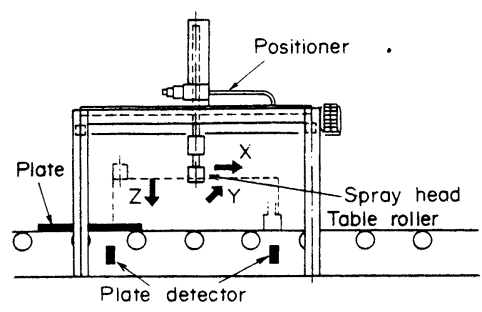

Fig.2. Automatic Stencil Machine

Table 1. Specificotions of Automatic Stencil machine

\begin{tabular}{|c|c|}
\hline Type & Dot spray type \\
\hline Dot size & $\varnothing 4 \mathrm{~mm}$ \\
\hline Dot distance & $6 \mathrm{~mm} \times 34 \mathrm{dot}$ \\
\hline Spray speed & $1.5 \mathrm{msec} / \mathrm{dot}$ \\
\hline Plate size & $\begin{array}{ll}\text { Thickness } & : 4.5 \sim 120 \mathrm{~mm} \\
\text { Width } & : 900 \sim 4500 \mathrm{~mm} \\
\text { Length } & : 1800 \sim 2500 \mathrm{~mm}\end{array}$ \\
\hline
\end{tabular}

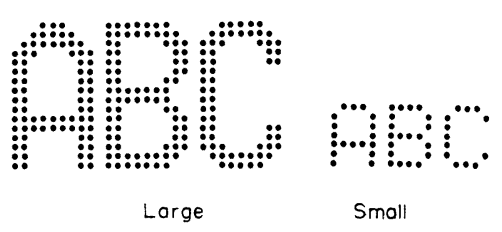

Fig. 3 Sample of letters 
(侏)日本製鋼所 室蘭研究所 ○福田 隆，清野芳紀 中島進, 前田栄二

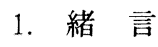

熱延クラッド鋼の接合性能は製造条件の影響を大きく受けるが、必ずしも製造因子の定量的な相関が 十分明らかになっているとはいえない。本報告では製造因子の中、酸化の影響を取り上げ、熱延時の酸 化傾向の異なる 2 種のクラッド鋼、すなわちSUS316Lステンレスならびにチタンクラッド銅の接合性能 に与える酸化の影響を基礎的に調查した。接合性能の評価には従来のせん断試験の他にはく離試験、接 合界面のKcならびにJc值の測定等により行なった。

2. 供試材ならびに試験方法

供試材の母材炭素鋼はSM50Bで合せ材は各々SUS316L抢よびTP35である。チタンクラッド鋼熱延時に は、新たに開発した特殊軟鋼をチタンとSM50Bの間にインサートした。熱間圧延圧着は1 パスで行ない、 その際圧下率を種々変化させ、すべて $3 \times 10^{-3}$ Torrのほぼ真空下で圧着した。酸化の影響を見る場合は熱延前 に予め合せ材側を $500{ }^{\circ} \mathrm{C}$ (SUS316L)ならびに $600{ }^{\circ} \mathrm{C}$ (チタン)で大気中にて酸化処理を行なった。

\section{3. 試験結果}

熱延後クラッド鋼の接合強度の測定ならびに接合界面のミクロ観察 を行ない下記のことが判った。

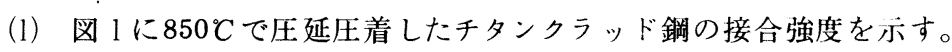
酸化処理したものは、しないものに比し接合強度は低い傎を示す。 10\%圧下率の接合界面のAES表面分析の結果、酸化処理時生成したチ タン酸化物は熱延時分解し酸素はチタン内部一固溶するとともに鋼 側の $\mathrm{A} l, \mathrm{Ca}$ 等と反応し酸化物を形成する。この酸化物が接合強度を 低下させた一因と考えられる。酸化処理しない場合、熱延時ならび にその後の加熱温度、時間の増大にしたがい接合界面の金属間化合 物の種類は $\mathrm{Fe} 2 \mathrm{Ti}+\mathrm{Fe} \mathrm{Ti} \rightarrow \mathrm{Fe} 2 \mathrm{Ti}+\mathrm{FeTi}+\mathrm{TiC} \rightarrow \mathrm{TiC} に$ 変化しながら層幅 が增し、せん断強度は低下する。一方はく離強度も同様に低下する が、TiCのみになると TiCの幅增大にしたがい、はく離強度は逆に上 年する。同じ加熱条件ならびに圧下率でも酸化処理したものは、し ないもの之は異なった金属間化合物の幅を示す。金属間化合物の生 成および接合強度に及ぼす酸化皮膜の影響について考察した。

（2）SUS316Lクラッド鋼の場合、酸化処理したものは母材鋼への酸素 固溶量が少なく酸化物のほとんどが鋼中の $\mathrm{Si}, \mathrm{Mn}$ 等に還てさされて $\mathrm{Si}$, $\mathrm{Mn}$ 等の酸化物として残存する。この残存酸化物の増大が接合強度に 及ぼす影響は一律ではなく、せん断強度に与える影響が小さいのに 比しはく離強度、さらにはKcおよびJc值に対しては大きな影響を与 える。(図 2 参照)

（3）接合界面の破壊勒性值の導入により、クラッド鋼の使用時の安全 性をより正確に評価できる。

<参考文献 $>(1)$ 大橋他: 溶接学会論文集 第 3 巻(1985)第 3 号

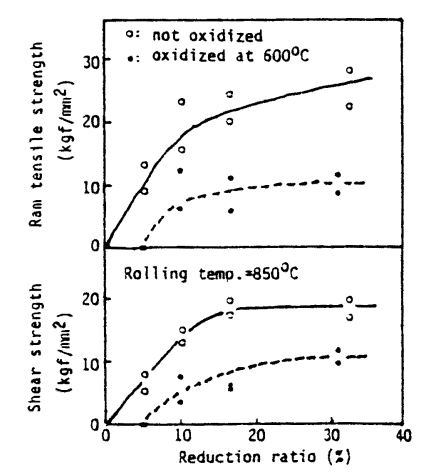

Fig. 1 Relationship between reduction ratio and bonding strength of titanium clad steel.

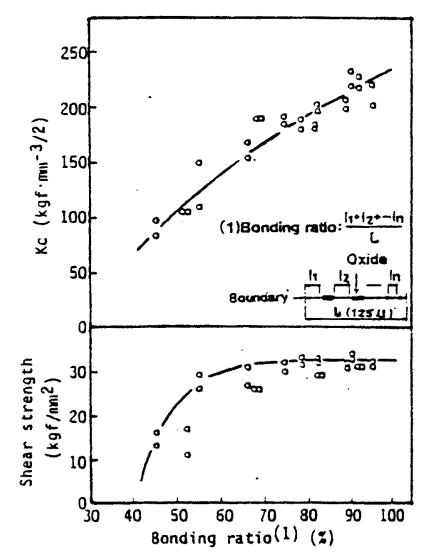

Fig. 2 Relationship between bonding ratio and bonding strength of $316 \mathrm{~L}$ clad steel. 
ラジオメータ方式成板温度計の設計，基礎試联

(マイクロ波ラジオメータ方式板温度計の開発一1)

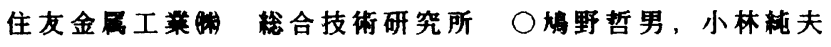

和歌山製鉄所砂原徽, 丸山晃

\section{1. 楮 言}

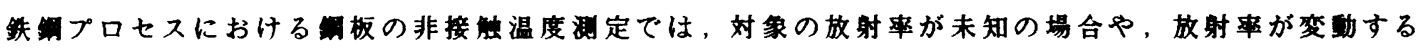

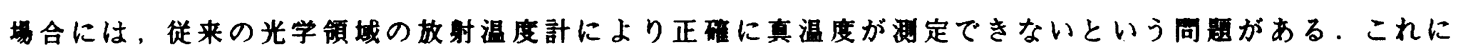
対して，マイクロ波ラジオメー夕を用いてマイクロ波带の度温度と放射率を同時に睡し，放射事変 娌を補傎して真温度を求める方法を考察し，ラジオメー夕方式板温度計の開発を行なった。

\section{2. 湘定原理}

マイクロ波带域における金属からの熟放射量はきわめて少ないため，Pig．1に 示すように板とそれに対向させた反射器とにより共振器を形成し，放射事が高 くなる共振周波数を含む一定帯城での共振器の度温度 $T_{\mathrm{R}}$ と反射事 $\bar{\Gamma}$ を湖定する。

板と反射器の放射來を $\bar{\varepsilon}_{\mathfrak{t}}, \bar{\varepsilon}_{\mathbf{n}}$ ，物理温度を $\mathrm{T}_{\mathfrak{t}}, T_{\mathbf{m}}$ とすると，共振器の回折損 失が彗視できる場合，次式が成立する。

$$
T_{\mathbf{R}}=\bar{\varepsilon}_{\mathbf{t}} \cdot T_{\mathbf{t}}+\bar{\varepsilon}_{\mathbf{m}} \cdot T_{\mathbf{m}} \quad \text { (1) }, \quad \bar{\Gamma}=1-\left(\bar{\varepsilon}_{\mathbf{t}}+\bar{\varepsilon}_{\mathbf{m}}\right)
$$

(1). (2)式より，板の真温度 $T_{\mathrm{t}}$ 次式で求めることができる。

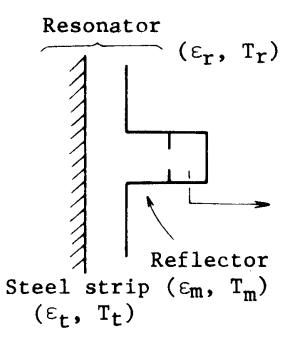

Pig. 1 Principle.

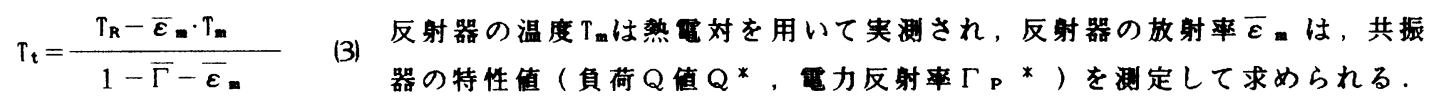

3. 睡定装

测定装置の棈成を唔，2に示す，

(1)反射器：回折损失を防止するため千ヨ 一ク榑造 フランジを取りつけた棈造を採用 した。(筩板との间翮 $\mathrm{d}: 25 \mathrm{~m}$ 以内)

(2)ラジオメー夕装蹎：1.7 G Hz近併を 共振周波数( $\left.f_{0}\right)$ として用い，度温度と反 射車をラジオメータにより测定した。共振 器の特性值は別の柽路を用いて测定され， 淔定值は反射器温度実测值と伴に計萛機に 取り込まれ板の真温度 $T_{\mathrm{t}}$ が求められる。 また，㜀板の振動に起因する共振周波数变

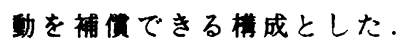

4. 定粘果

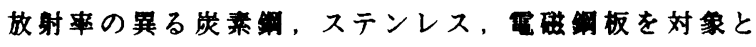

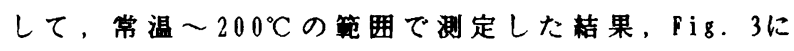
示すように，放射事補正して测温度 $\sigma \leqq 10.5 \mathrm{~K} て ゙$ 测定 可能なことを磼認した．

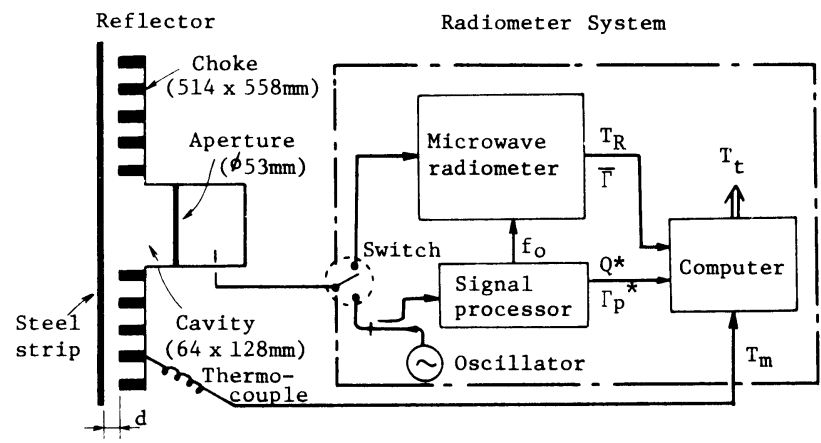

Fig. 2 Micromave Radiometer system.

\section{5 . 枯言}

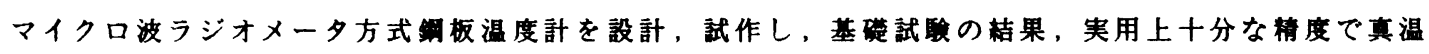

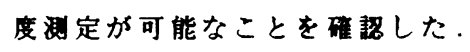


' $87-\mathrm{S} 1070$

住友金属工業侏和歌山製鉄所 ○砂原 徹 高橋昭夫 丸山 晃

総合技術研究所鳩野哲男

\section{1. 緒 言}

基礎実験の結果から、マイクロ波ラジオメータを鋼板の非接触温度測定に適用可能であることが判明 した。今回、試験炉での確認試験後和歌山製鉄所連続焼鈍無酸化炬に本法を適用し、精度良く測定でき たので報告する。

\section{2. 試験炉での試験}

2.1 反射器温度の均一化

鎆板の温度測定の精度を上げるためには、反射器の 温度分布を極力小さくする必要がある。そこで Fig. 1 . のようなチョーク構造を持ち内部を水が循環する水冷 構造を採用し、反射器の温度分布を $\pm 3{ }^{\circ} \mathrm{C}$ とした。

\section{2 測温精度}

放射率の異る炭素銅、電磁鋼板を対象として 200 $800^{\circ} \mathrm{C}$ の範曲で板温実測值（熱電対を鎆板に埋め込み 測定）と、ラジオメータ測定值と比較した結果 Fig.2. に示すように $\sigma \leqq 13.4$ 足で測定できることを確認した。

\section{3. 実操業における镐板温度測定結果}

従来の光学式放射測温法では放射率変動が激しく、 測温誤差の大きい連続焼鈍無酸化炉出側において、測 温試験を行った。

Fig.3.に示すように、鋼板の上面をラジオメータ方 式銅板温度計、下面を光学式放射温度計 $(\mathrm{Ge}$ :放射率 $=0.7)$ を用いて測定した。測定結果の一例を F i g . 4. に示す。材質変更時 $(\mathrm{Si} \%: 0.1 \rightarrow 0.6$ ) 従来の放射温度 計が放射率変動により測温誤差が大きいのに比べ、 放射率変動を正しく補正して 通板速度增加による材温降下 を良好にとらえている。

\section{4. 結 昌}

マイクロ波ラジオメ一タ方 式鋼板温度計を開発し、実ラ インで放射率変動に左右され ずに真温度測定が可能なとと を確認した。現在操業並びに 品質の安定化を目的に実操業 への導入を検討中である。

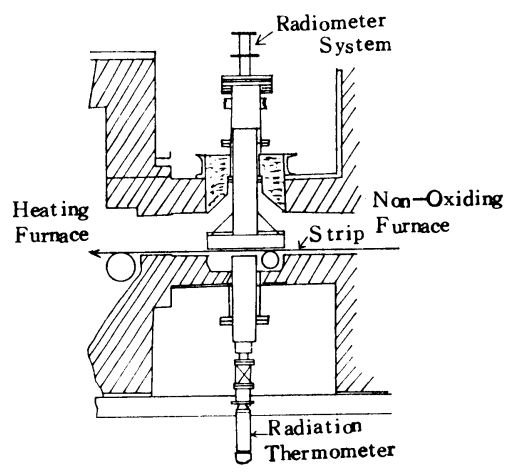

Fig. 3. Equipment for On-line Test

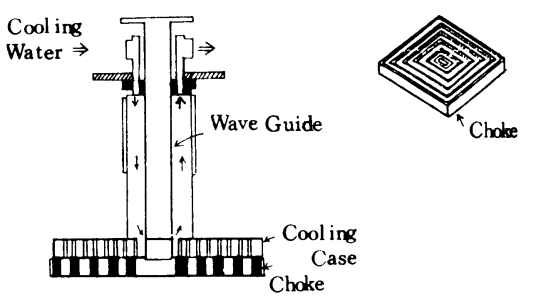

Fig. 1. Reflector

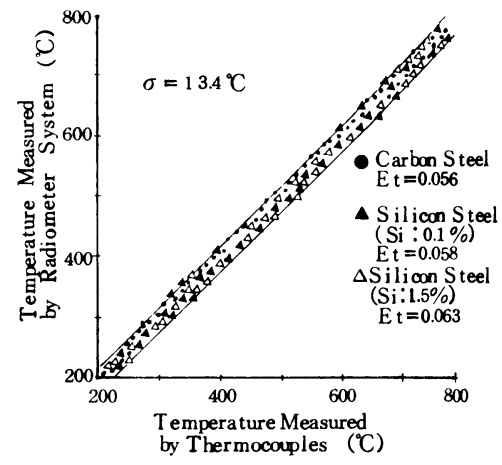

Fig. 2. Experimental Results

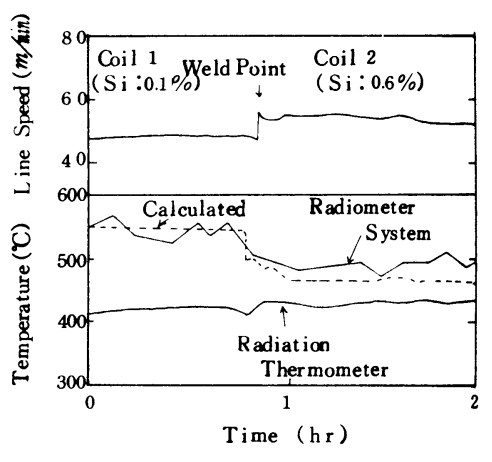

Fig. 4. On-line Results 


\section{（335） オンライン用高速エリプソメータの開発}

\section{日本鋼管侏 システム技研 ○宮崎孝雄 山田善郎}

\section{1. 緒 言}

数 10 数 $100 \AA$ の薄膜厚を測定する方法としてエリプソ法が知られている。従来のエリプソ法として 消光法や回転検光子法 ${ }^{2)}$ が提案されているが、高速で動く測定対象に適用するてとは, 原理面, エンジニ アリング面から困難であった。この問題を解決するため、エリプソメトリーの原理面から検討を加え, 簡単な光学系亡高速測定を特徴とする $3 \mathrm{ch}$ 型エリプソメータを開発した。との原理を錫めっきライン のオンライン塗油量計に応用し良好な結果を得た。

\section{3 ch型エリプソメータの原理}

$$
\text { エリプン法は、 } 2 \text { づエリプソパラメータ }
$$

$\Delta$ (位相角)，安（振幅比角）の測定值加ら 一定の関係式に基づいて膜厚を求める方法で ある!'

本エリプソメータは、測定時間の高速化に 対応するため反射光を 3 本のビームに分ける ととにより, 可動部なしでエリプソパラメー 夕を求めるものである。入射光を $-45^{\circ}$ の直 線偏光とする。各チャンネルの測定ゲインを 調整後, 各検光子方位角 $\mathrm{A}_{1}, \mathrm{~A}_{2}, \mathrm{~A}_{3}$ ⿸ $0^{\circ}$,

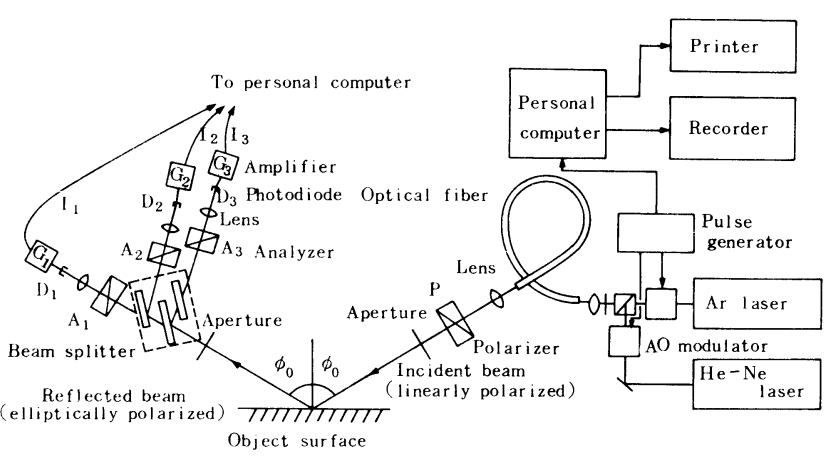

Fig. 1 Schematic diagram of 3 channel ellipsometer $45^{\circ},-45^{\circ}$ に固定する。乙の状態での各チャンネルの光量出力值 $\mathrm{I}_{1}, \mathrm{I}_{2}, \mathrm{I}_{3}$ を用いて、エリプソパラメータは, 次式で表わせる。 $\cos \Delta=\frac{\mathrm{I}_{3}-\mathrm{I}_{2}}{2 \mathrm{I}_{1}} \sqrt{\frac{\mathrm{I}_{1}}{\mathrm{I}_{2}+\mathrm{I}_{3}-\mathrm{I}_{1}}}, \mathrm{t}$ an $\psi=\left|\sigma_{1} \sigma_{2}\right| \sqrt{\frac{\mathrm{I}_{1}}{\mathrm{I}_{2}+\mathrm{I}_{3}-\mathrm{I}_{1}}}$

ここで, $\left|\sigma_{1} \sigma_{2}\right|$ は、ビームスプリッタの屈折率, 反射光の入射角によって決まる定数である。

3. オンライン計測への適用

透明で $100 \AA$ 以下の溥膜の場合, 膜厚 $\mathrm{d}$ と位相測定値 $\cos \Delta$ は比例関係にある。また, 下地の位相値 $\cos \Delta_{0}$ は, 表面粗さ等 により変動するが， 2 波長 $\lambda_{1}, \lambda_{2}$ に対する測定值の間には一定 の関係があり、膜厚 $\mathrm{d}$ と等価な単位面積当りの油量 $\mathrm{m}$ は結局 $(2)$ 式で近似できる。

$$
\mathrm{m}=\kappa_{0}+\kappa_{1} \cos \Delta \lambda_{1}+\kappa_{2} \sqrt{\kappa_{3}+\frac{1}{\kappa_{1}} \cos \Delta \lambda_{2}-\cos \Delta \lambda_{1}}
$$

$\kappa_{0} \sim \kappa_{3}$ は, 実験的に決まる定数。 $\cos \Delta \lambda_{1}, \Delta \lambda_{2}$ は波長 $\lambda_{1}$, $\lambda_{2}$ における測定值。オンライン試娩の結果, $\pm 1 \mathrm{mg} / \mathrm{m}^{2}$ の精 度を確認した。

\section{4. 結 言}

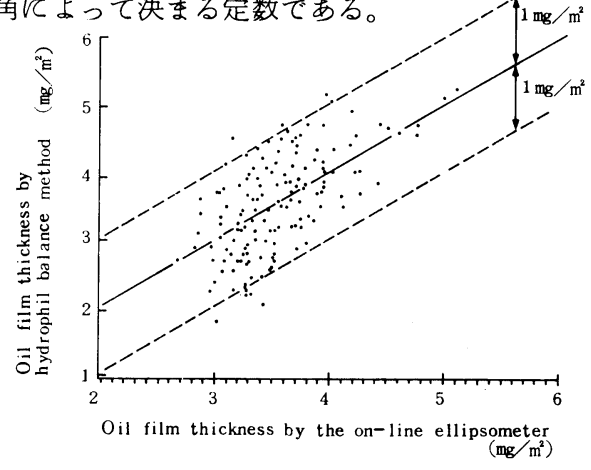

Fig. 2 Measured values by the on-line ellipsometer are plotted against those by hydrophil balance me thod

単純な光学系をもち、オンライン測定に適する $3 \mathrm{ch}$ 型エリプンメータを開発した。この原理による 2 波長 $3 \mathrm{ch}$ 型エリプソメータを錫めっきラインの塗油膜測定に適用し、オンライン化の見通しを得た。

5. 文 献

1) R. M. A.Azzam \& N.M. Bashara : Ellipsometry and polarized light, NorthHoll and, 1977 2) P.S.Hauge : IBM J.Res. Devel. 17 (1973) 472 
'87- S 1072

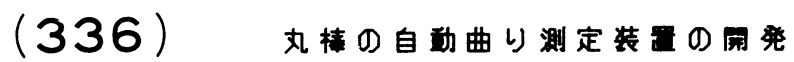

住友金晋工羓（株）梒铁所

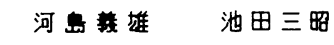

森的一村上男

○池部吾八

1、始めに

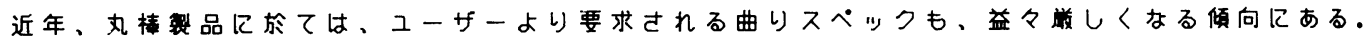

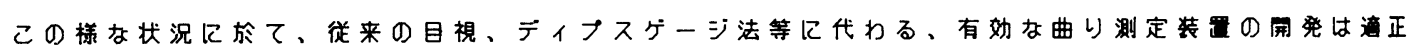

な姃正を行う上でも、また製品の品酸保を行う上でも、重要であり、ニーズの高いものである。

本稿では今回闰発した自勤曲り測定装置について、報告する。

\section{2. 装置摡要}

Flg 1 亿曲り測定装置摡要を示す。 本装置は、回転ローラー(ワーク長さ方向 己力所)、回転パルス娭出部、夜位センサ

一（長さ方向袮個）、 $\mathrm{O}^{\circ}$ 点模出部、CP U、CRT\&プンター等で㭋成される。 パルス発佮器よりのパルス数、マークセ ンサーよりの $0^{\circ}$ 点信号、变㕕センサーより の信号をデーターとして取込み、所要の処 理を行ない曲り状態線图を作成する。

3.曲り状態線図

Fig 2 に曲り状態線图の基本を示す。 それぞれの変位センサーのデーターより、 回䖝方向の変位を演籍し、各位相每に長さ 方向に遭結することにより、曲り状態線図 が得 5 れ。。

4. 曲り测定結果

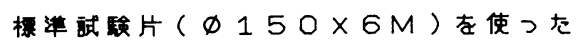
娭䃌により以下の硣元を確証した。

\begin{tabular}{|c|}
\hline 测定耕度 $: \leq \pm 0.3 \mathrm{~mm}$ \\
测定時间 : $\quad 3 \mathrm{~m} / \mathrm{n} / \mathrm{P}$ \\
\hline
\end{tabular}

5. 装買（システム）の待徽

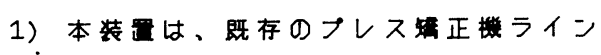
等に容易に組込む事が可能であり自预曲 り測定を可能とするものである.

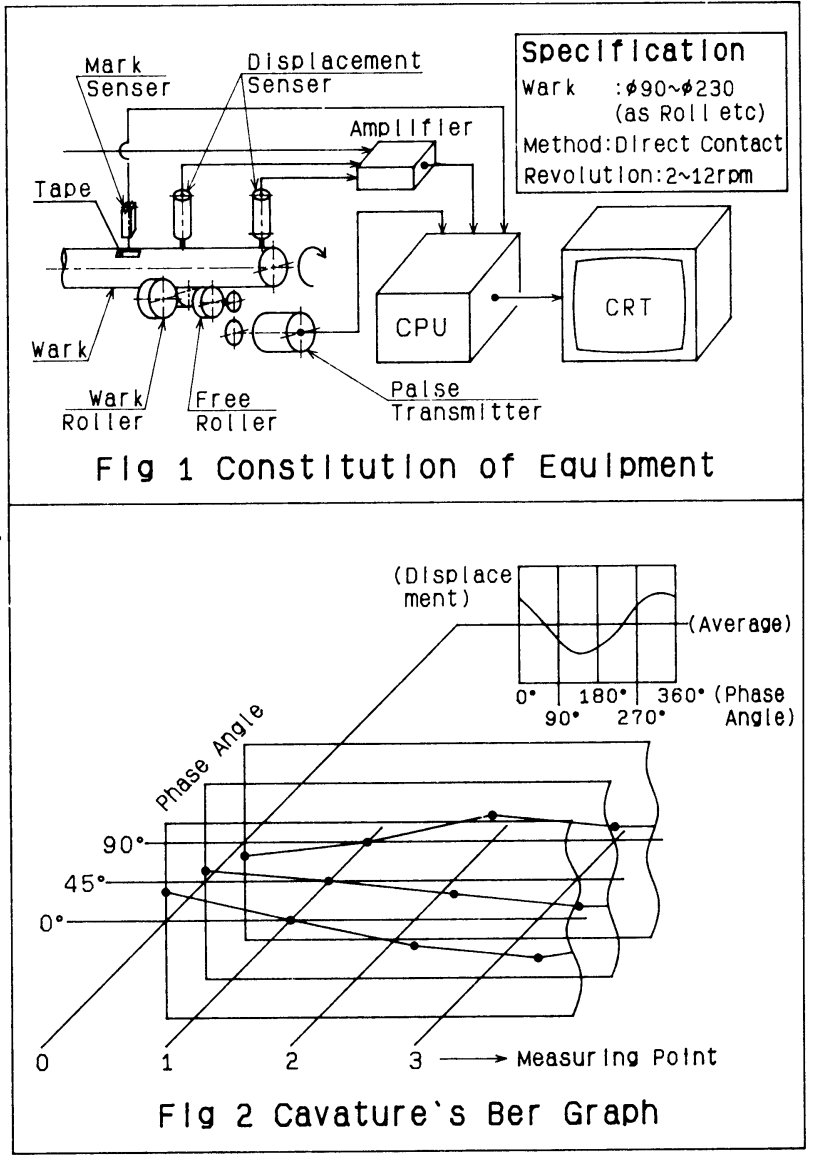

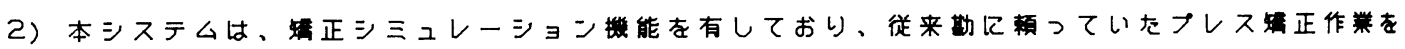
もサポート可能なものである.

6. 終りに

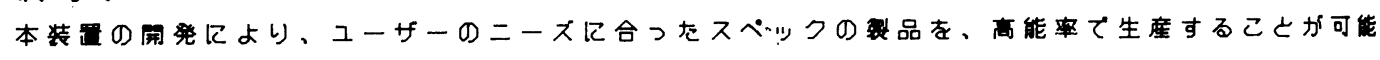

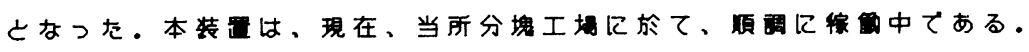




\section{（337）ロールプロフィル計を使ったロール管理}

1. 緒 言

冷延, 表面処理工場各プロセスラインにおいてはロールに由来した品質欠陷発生が数多くある。それ らの発生原因の中でロール形状は重要な要因の 1 つであるが、その定量的管理には多大の労力を要する。 そこでロール形状を簡単な操作で測定可能なロールプロフィル計を開発したので、その装置概要および 適用例について報告する。

\section{2. 装置概要}

ロールプロフィル計の装置概要を Fig. 1 に示す。 動作 ロール胴にカーソル付ストレッチ架台一式 を乗せ、センサを装備したカーソルをストレ ッチレール上を前進あるいは後進させ、その 時センサの読み取った信号を増幅しチャート

に出力させる。

仕様 走行スパン： $1500,1800 \mathrm{~mm}$

測定可能口ール径 : $\phi 100 \sim \phi 1500$

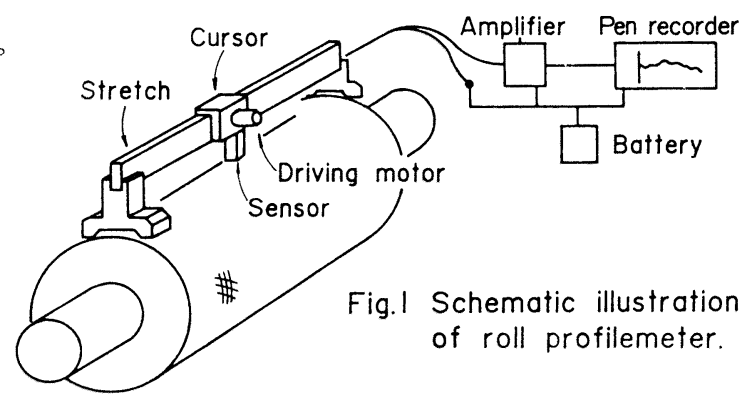

センサ : 光学式距離計, 渦流式距離計

センサ走行速度 : $100 \mathrm{~m} / \mathrm{sec}$

総合精度 : $20 \mu \mathrm{m}$ (分解能 $5 \mu \mathrm{m}$ )

電源 : バッテリ式

3. 適用例

錫めっきライン出側ルーパ内で偏摩耗したロルの摩耗した肩の部分より、ストリップ（ $0.15 \times$ 812 , 調質度 $\mathrm{T}-3$ ) に絞りが発生した例をFig. 2 に示す。

4. 効 果

(1) 計測時間は $1 \sim 2$ 分と従来の $1 / 3 \sim 1 / 5$ とな り作業性が向上した。

(2) ストレッチ\&スキミゲージでは測定不能であすั った局部摩耗やロール胴全長の詳細測定が可能 になった。

(3) ロール形状品質欠陷発生防止のための管理値 の定量化が容易になった。

5. 結 言

プロセスラインにおけるロール性品質欠陥のう

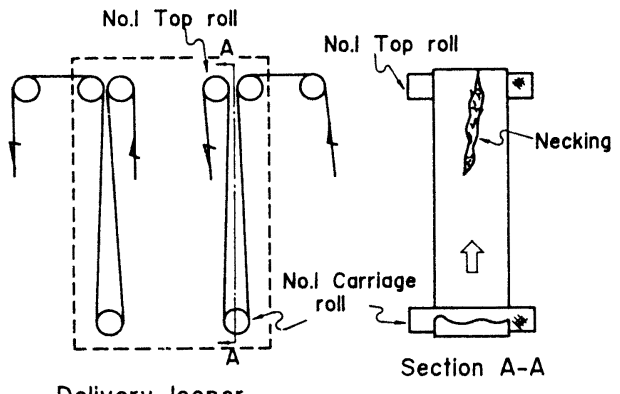

Delivery looper

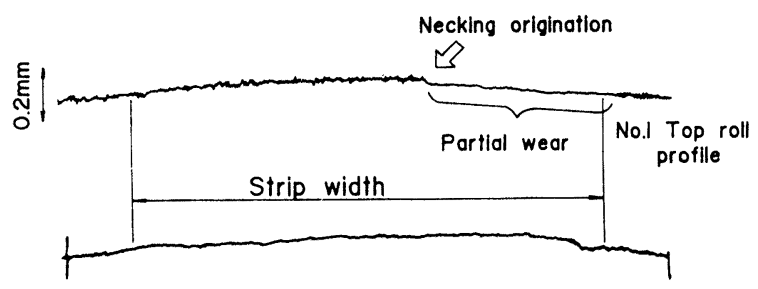

Fig.2 Example of necking caused by bad No.l Carriage roll profile roll profile in looper.

ち、ロール形状に起因した欠宿の原因を定量的に把握するために保全のッールとしてロールプロフィル 計を開発した。それによりロール形状の管理値の定量化が容易になった。今後これを全ての重要ロール に適用扗大し、品質保全を更に強化していきたい。 


\section{（338） レーザーストリーク写真方式スラブ表面疵検査装置}

\section{1. 緒言}

新日本製鐵侏) 名古冣製鐵所 ○佐藤 邦章 長谷 真二

当所では，C C スラブの製造過程において発生する疵，例えば，機峨的又は治金的に発生するロール 疵, 割れ疵等の「スラブ表面疵」を製鋼工程において早期に発見し処置するととにょり (1)大量異常発 生防止 (2) C H C R 量の払大 (3)次工程へのスラブ品質保証等の効果を狙い, 品質保証体制をより完璧

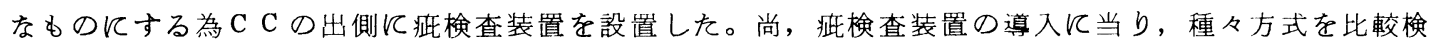
討した結果，高精度で安価な「レーザーストリーク写真方式スラブ齿検」を採用したので，その概要を 紹介する。

\section{2. 基本原理}

レーザーストリーク写真法とは，赤熱鋼板 の温度ムラ，陽炎，外乱光の影響を除を，冷 間と同じ条件で疵の撮影が行えるよう，(1)光 源としてアルゴンレーザー光（緑色）を使用 し，(2)カメラ側は自発光をフイルターでカッ トし，レーザー光の指向性を利用して強調さ れた疵の影を撮影するもので, (3)縦, 横疵の

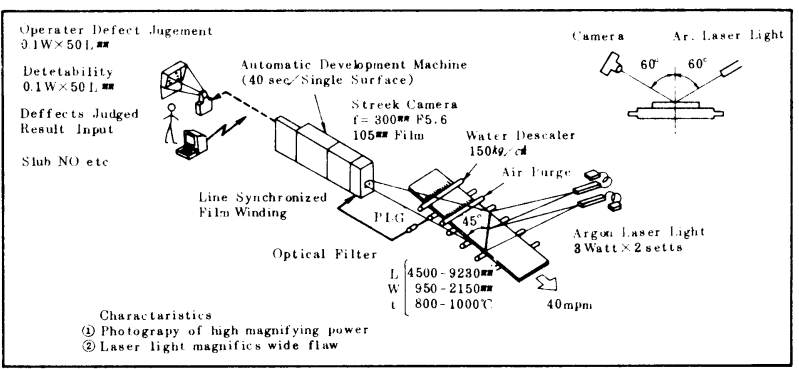

Fig-1. Principle of Streek Photograpy by Ar Laser 両方を検出するためにスリット光斜向角 45 度で照射し，(4)鋼板長手方向に同一分解能で疵を撮影する ために, フィルムを被検査材と同期して送る。(5)をた, 得られたフイルムは, 迅速現像機処埋を採用し, 現像, 定着, 水洗, 乾燥を短時間で完了させ,オペレーター観 察を含めて数分間で趾の㭘査が終了するととを特徴とする。

\section{3. 疵観察データー及び写真}

熱間スラブを撮影し，オペレーターが投影観察した結果と， 冷却後のスラブ表面を観察，照合した結果をFig一 2 亿示す。 オペレーターがフィルムを拡大投影して発見した疵の数と長さ は泠片観察したものと略一致している。

写真は観察データーの中でむ小さい「緃割れ疵」で冷片観察 で照合した結果は, 割れ巾 $=0.1 \mathrm{~mm}$, 長さ $=50 \mathrm{~mm}$ であった。 写真結果から判断すると長さに対し割れ巾が払大されて写って おり，レーザー光による疵幅拡大効果を確認でさる。

\section{4. 結 論}

従来スプレー方式のため全量冷片にし手入れ処理を実施して レた熱薄八イテン材等に対し, 昭和 62 年 1 月より, 本装置を 利用した疵グレード別管理をするととにより無手入化向上及び C H C R 化拡大を図ってきた。

直近においては, 本装置の導入により本対象材において C H $\mathrm{C} \mathrm{R}$ 化率約 $70 \%$ 亿達してをており, 今後更にスラブ疵検查装 置を有効利用し， C H C R 向上のための C C 工程能力の一層の 向上を図っていく。

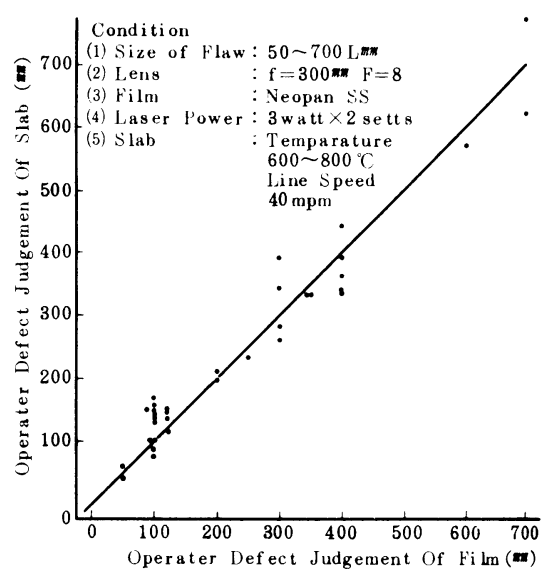

Fig-2. Ditetabiity

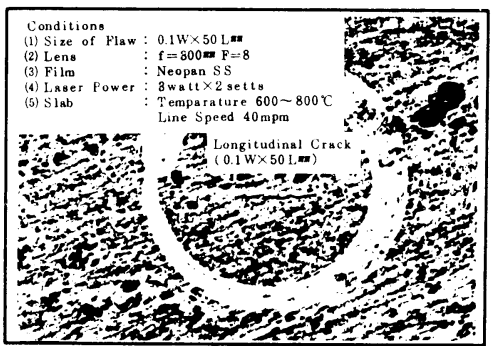

Fig-3. Longitudinal Crack Photo Data 
住友金属工業(侏) 和歌山製鉄所 正田真一郎 ○坪田元康

$$
\text { 荻野忠昭 吉川英二 }
$$

\section{1. 緒}

電縫管ミル 高周波溶接機の出力は、高周波かつ特別高圧であるため、正確な計測が困難であった。 本㧨では最近、低価格となったディジタルメモリ、マイコンシステムを応用した、高周波溶接機出力計 測システムの概要を報告する。

\section{2 . 計測システムの概要}

従来、高周波出力の計測はアンテナ法による波形 観測が主で、正確な定量計測は困難であった。

高周波出力（電圧・龟流）の正確な計測を行うには

（1）周波数特性の良い（応答の良い) 検出器

(2) 高周波信号の正確な伝送技術

(3) 高速アナログーディジタル変換技術等の技術が 必要である。

今回、乙れらの技術をマイコンを核にして組み合わせ

F i g . 1 亿示すシステムを構筑した。

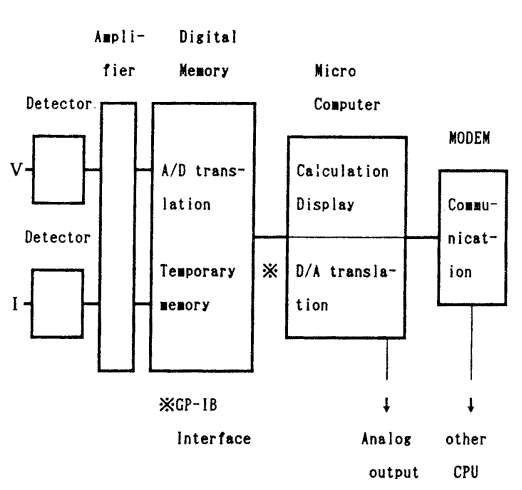

Fig. 1 Outline of System

本システムでは、娭出器からの信号をレベル変換後、ディジタルメモリに伝送。ディジタルメモリで サンプリング $\mathrm{A} / \mathrm{D}$ 変換したデータを演算処埋させることを特徴としている。高周波信号のサンプリン グ時間を最高 $20 \mathrm{~ns}$ とし、基本波成分（数百 $\mathrm{K} \mathrm{Hz}$ )のみならず、高周波成分（数 $\mathrm{M} \mathrm{Hz}$ )をも正確にデ 一夕変換させている。また高周波電圧と電流は同時サンプリングとし、マイコンでの高周波電力・損失

・負荷インピーダンス等の演算を可能としている。

またマイコンシステムの適用により、(1)解析プログラムが使用者側で作成・修正可能。（2汎用ソフ トゥェア(市販)の使用が可能。（3)モデム等を用いた信号の長距離伝送が可能等発展性のあるシステ ムとなっている。

\section{3 . 計測結果}

本システムで計測した高周波溶接機の出力 (プレート) 電圧・電流波形をFig.2に示す。 高速サンプリングにより高周波成分も正䧺に データ変換されている。

F i g. 3 は、計測信号をマイコンで演算し た結果を示している。高周波溶接機の状態管 理用に高周波電力・効率・負荷インピーダン スも合わせて演算出力している。

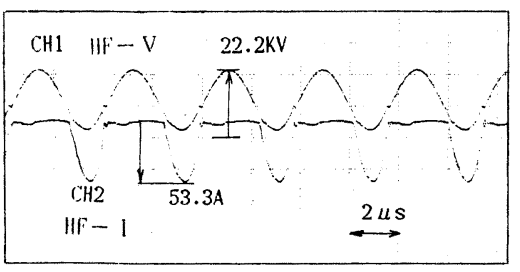

Fig. 2 Example of Measured Data (liave form)

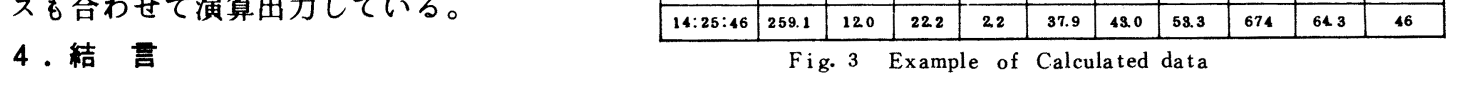

従来、困難であった高周波出力（電圧・電流）の正確な計測が可能となったばかりでなく、遠方の制 御室での高周波溶接機の状態監視をも可能とした。 


\title{
（340）Ｓ A W アーク電圧波形解析装置の開発
}

\author{
住友金属工業（株）＼cjkstart和歌山製鉄所 稲垣美民＼cjkstart荻野忠昭
}

○一入啓介

総合技術研究所 勝本憲夫

\section{1 緒 言}

従来より S A Wの品質はアーク電圧波形と大きな関係があるといわれている。しかし、アーク電圧波 形を統計的に評価することは非常に大がかりな装置を必要としたととから十分に行なうことかできなか った。とてろが電子技術の発達により比較的容易にアーク波形の統計的評価が可能となってきた。

今回、この技術を取入れアーク電圧波形を解析し S A Wの欠陥発生との関係を調査することを試みた ので報告する。

\section{2 装置概要}

F i g.1に今回開発した装置の構成を示す。主な特徵としては下記の様な点がある。

(1)高速 $\mathrm{A} / \mathrm{D}$ 変換 (最高 $2 \mu \mathrm{s}$ e c )

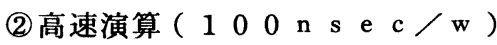

(3)プログラム変更容易 ( B A S I C )

また F i g . 2 にアーク電圧波形の模式図を示す。
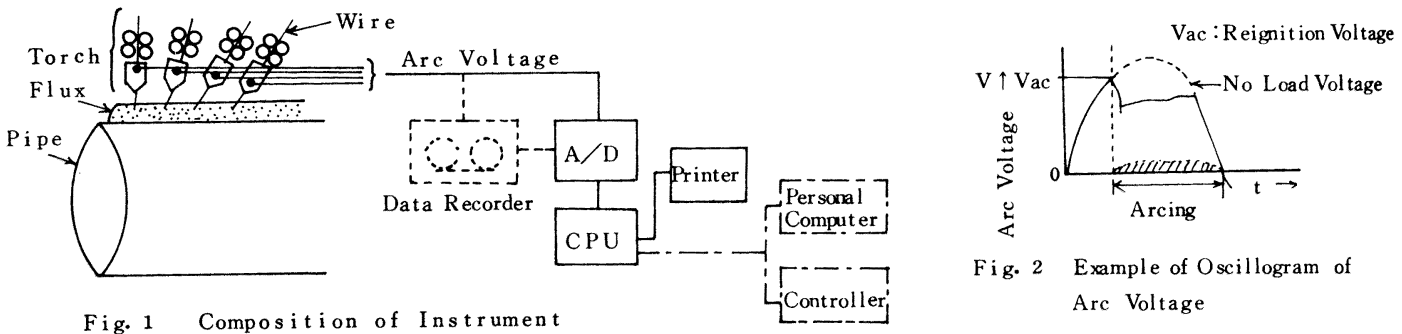

Fig. 2 Example of Oscillogram of Arc Voltage

\section{3 検时結果}

欠陥発生部のアーク電圧波形について以下の様な事が認められた。

(1)欠宿発生時には、最終極の波形が乱几、再点弧電圧も上昇する（Ｆｉ g ．3）。

(2)最終極のアーク電圧波形監視で溶接状態の管理が可能である。

(3)パイプ全長の再点弧電圧の標準偏差の分布と欠陥発生率の分布が同じ傾向を示す（F i g . 4)。

\begin{tabular}{|c|c|c|c|}
\hline No Defect & Var & Slug Inclusion & Var \\
\hline & & & \\
\hline
\end{tabular}

Fig. 3 Oscillolgram of Arc Voltage

\section{4 結 謇}

本装置を用い、最終極のアーク電圧の再点弧電圧 の標準偏差を監視することにより、溶接品質の管理 が可能であることが確認された。

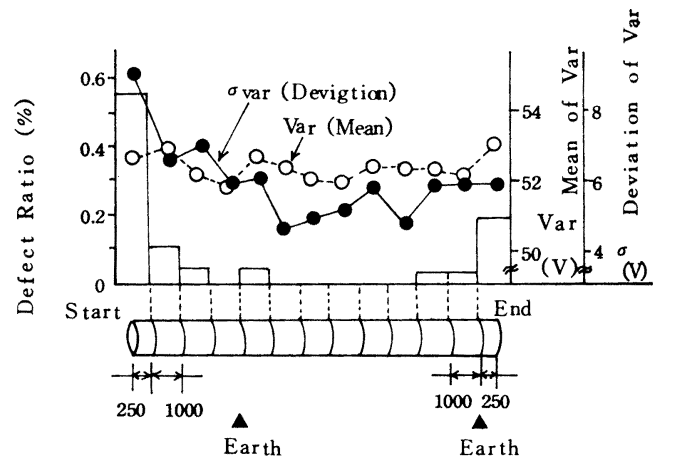

Fig. 4 Defect Ratio - Reignition Voltage of Trail Electrode 


\section{(341) オンライン鉄損测定装寘の開発}

' $87-$ S 1077

住友金属工菜制御技術センタ 和歌山製鉄

\section{○石原道章}

和智賁行, 中西功, 砂原徹

\section{1. 楮 言}

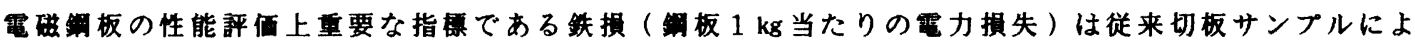
るエプスタイン試駩で評洒されてきた。铁損湘定をオンラインで実施することは操莱管理，步留向上の

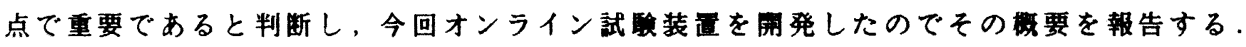

2. 测定原理及び結果

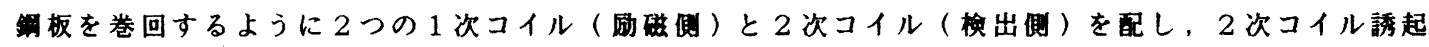
電圧を一定にするように 1 次コイルの励磁電流を制御する。励磁電流周波数を50H ととし，2 次コイ ル電圧と 1 次コイル電流を電力計に入力する．更に，板幅計，板厚計より，板幅，板厚を入力し，密 度，実奻磁路長をかけあわせて制板重量を求める．電力計出力（组板の電力損失）を重量で除すること により，铁椇值 $\mathrm{W}_{15} / 50$ （励磁周波数 $50 \mathrm{~Hz}$ ，最大磁束密度 $15 \mathrm{kG}$ のときの鉄損）が测定可能となる。

\section{本装宣の特徵は，}

i） 1 次コイルを分割型にすることにより，2次コイル部に均一磁場簕囲を確保（『ig. 2）．

又，分割型のため，板振動抑止用口 ールの設征が可能となり测定の安定度が 增大。

ii) 2 次コイル誘起電圧の波形歪率を同時 に测定し，波形歪で測定铁损值を補正 (Fig.3）し，エプスタイン武槙值対応 $\pm 5 \%$ 精度で测定可能。

である。

3. 結 言

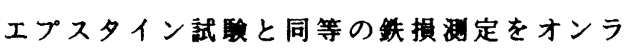
インで実施する装軎を開発した。

Magnetic flux density (kG)

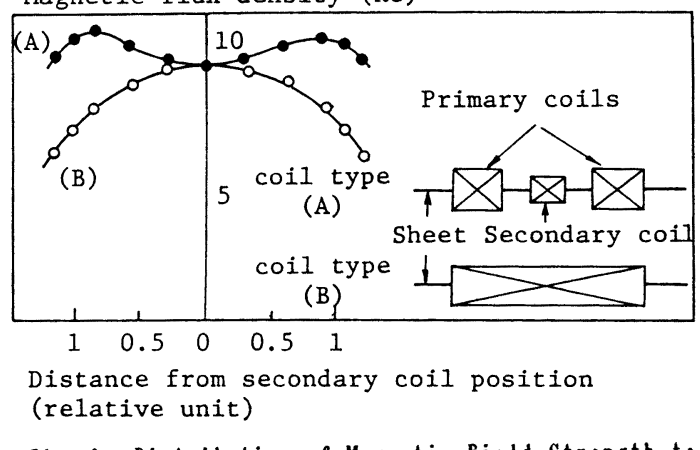

Pig. 2 Distribution of Magnetic Pield Strength to Rolling Direction.

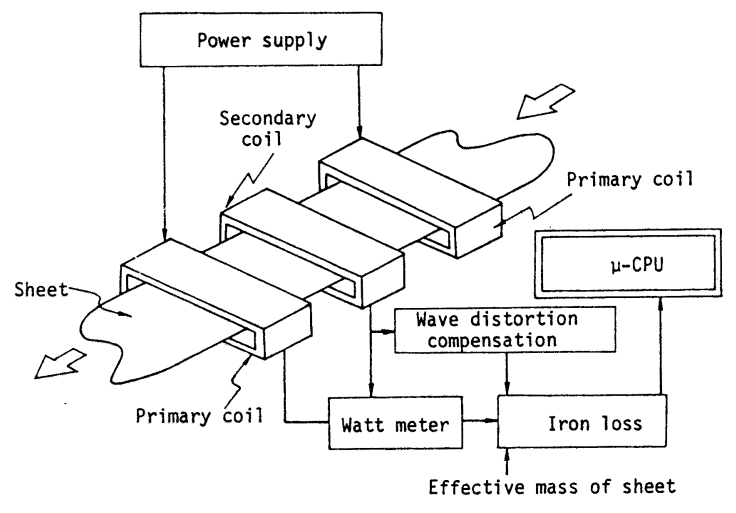

Fig. 1 Block Diagran of Iron Loss Measuring System.

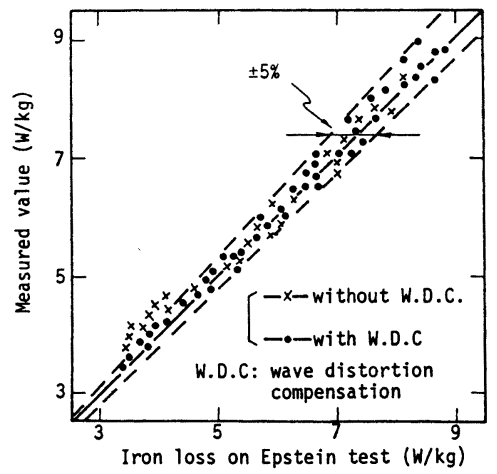

Pig. 3 Iron Loss on Epstein test v.s. Measured value. 


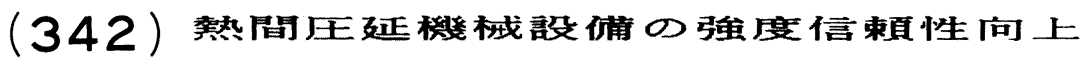

川崎製鉄水鳥製鉄所 ○井上紀明 池田晴行 中野賁則 石川貴章

\section{1. 緒言}

加熱炉省エネルギーと圧延材の材筫制御のために低温圧延や高圧下圧延が行われ，压延負荷增大による設借損伤が 增加してきた。最近は連鋳一熱間圧延間の同期化・連続化が進み，設備損賃は生産機会の大きな損失となる。そこて 機械設備の総合的な強度検討を行い，改善を実施し強度信頼性を向上させた。

\section{2.ミル駆動系の強度向上}

ミル駆動系の強度検討の結果をFig.1 に示す。ミル駆動系 では、スピンドル，主減速機歯車，ピニオンスタンド菡車の 安全率が他の部位に比へて低く，実際に設備損傷が発生して いた。

(1) 高強度SJの開発1) 3) わにぐちに応力集中が発生しない 形状のスリッパメタル型スピンドル（SJ）を考案し，実糇で 2 倍の強度を有していることを検証した後に実機に適用した。

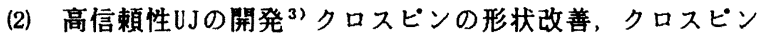
の防食方法の考案，スプライン軸の強度向上などにより，UJ の強度不足に起因するトラブルを皆無にした。

(3) ピニオンスタンド歯車の強度向上 ${ }^{3)}$ インボリュート歯車 とシンマーク歯車を比較して, 安価なシンマーク歯車を操用 し面圧強度と曲げ強度を2.5 倍に向上させた。

3. ミル圧下系の強度向上 ${ }^{3)}$

FEM 解析による応力評価に基つく（Table 1)点検の結果， 圧下ナット格納部と八ウジングライナー取付座に釷裂を発見 した。応力集中部のラウンドオフを行い疲労安全率を 1 以上 に改善して、ハウジングの更新を不要にした。

\section{4. 負荷監視と寿命予測}

今後の試験圧延時の圧延トルクの負荷監視，および実負荷 歴の把握による残存寿命の推定, さらに重要回転機器の故障 監視を目的としてFig.2の監視システムを設置した。 5. 結言

種々の設備改善により，保全費用の削減と安定操業の維持 に大きな効果を発揮することができ， 3 時間以上の設備停止 となる大きな設備故障は，昭和60年から発生していない。 <参考文献>
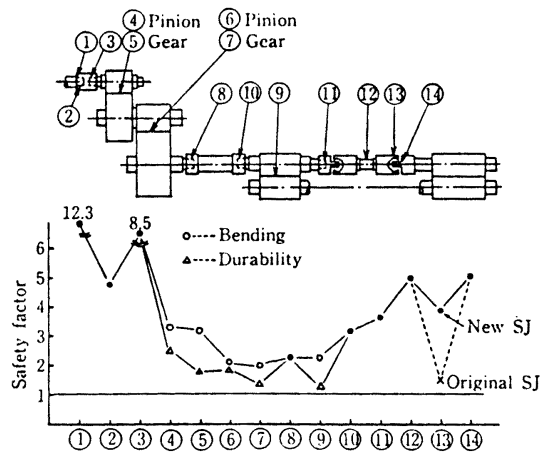

Fig. 1 Safety factor of driving section (R2 stand)

Table 1 Calculated stress and safety factor ( $R 2$ housing)

\begin{tabular}{c|c|c|c}
\hline Symbol & $\begin{array}{c}\text { Calculated stress (FEM) } \\
\left(\mathrm{kgf} / \mathrm{mm}^{2}\right)\end{array}$ & S.F. & Calculated point \\
\hline $\mathrm{A}$ & 12.74 & 1.05 \\
$\mathrm{~B}$ & 3.59 & 2.57 \\
$\mathrm{C}$ & 8.13 & 1.12 \\
$\mathrm{D}$ & 16.98 & 0.78 \\
$\mathrm{E}$ & 7.51 & 1.38 \\
$\mathrm{~F}$ & 16.98 & 0.61 \\
$\mathrm{G}$ & 13.33 & 0.80 \\
$\mathrm{H}$ & 4.16 & 2.44 \\
\hline
\end{tabular}

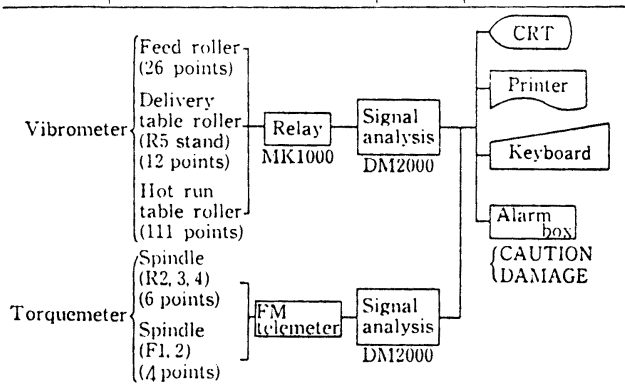

Fig. 2 Michine monitoring system in hot strip mill plant

1）川崎製鉄郴：「スリッパメタル型自在カカップリング」，特願昭59-80044

2）井上ら：川崎製鉄技報，16(1984)3，221 231

3 ）井上ら：川崎製鉄技報，19(1987)1，58～63 


\begin{tabular}{|c|c|c|c|}
\hline 新日本製鐵㑣) & 第一技術研究所 & 豊田利夫 & 中嶋 \\
\hline & & & \\
\hline
\end{tabular}

\section{1. 緒 言}

振動を測定するととによって回転機械の異常の有無を診断する筒易診断機器が各方面にかなり普及し てきた。これらのうち多くが指向しているのは測定データの傾向管理やある程度の精密診断までも行な おうとする高機能化である。しかし二ーズはそれだけではない。とのたび不要な機能を除いて常時携帯 できるような単機能化，小型化を指向した新しいタイブの振動測定器の開発に着手した。

\section{2. 仕様と構成}

この測定器には 2 種類あり, 振動の周波数帯域を大きく 2 つに分けた場合, アンバランスやミスアライメントなど の回転機構の診断を目的としたいわゆるLoレンジ診断専用 のものと，てろがり軸受などを㟝断するHiレンジ診断専用 のものである。このうち開発を完了したLoレンジ用涀定器 の仕様をTable 1 亿示す。との測定器では振動加速度を検 出し電気的に振動速度に変換して表示している。

開発のポイントは高度な機能を満足しながらどれだけ小 型化できるかであるが，まずFig.1亿示すように圧電素子 と探触棒を一体化し，これをパッキンでケースから浮かせ た構造とした。とれにより接触共振の影響を取除き測定周 波数領域における平坦な周波数特性を実現するととができ た。また信号処理回路についてもフィルタや積分器などの アナログ信号処理部はハイブリッド化し, ディジタル表示 部にはワンチッブ化した I C と L C D を用いた。その他の部 分についても既存のI C を效果的飞使用することにより,

Fig. 2亿示すような非常にコンバクトな測定器を開発する ことができた。Fig. 3 とはこの測定器を用いて回転機械の 簡易診断を行なっている様子を示す。

\section{3. 評価テスト}

測定 (表示):值が押付け力によってどの程度変化するか を調べたととろ， $0.5 〜 2.0 \mathrm{~kg} \mathrm{f}$ 範囲であれば測定誤差は $5 \%$ 以内納まるととを確認した。また新日鐵の各製鉄所 におけるモ二タ調查の結果, 超小型であるため例えば作業 服のボケットに入れて常時携行でき, 点検作業の幅が広が るというととで非常に好評を得た。

\section{4. 結 言}

設備の回転機構の簡易診断を目的としたLoレンジ用超小 型振動測定器の開発を完了した。引続きHiレンジ用測定器 の開発に取組んでいる。
Table 1 Specification of machine checker (Lo range type)

\begin{tabular}{|c|l|}
\hline Item & \multicolumn{1}{|c|}{ Specification } \\
\hline Pick-up & Piezoelectric acc. pick-up, 50pC/G \\
Measuring range & $0.1 \sim 99.9(\mathrm{~m} /$ sec $)$, Average value \\
Frequency range & $3 \sim 1000(\mathrm{~Hz})$ \\
Size & $20 \times 18 \times 150(\mathrm{~mm})$ \\
Weight & Less than 62 grams \\
\hline
\end{tabular}

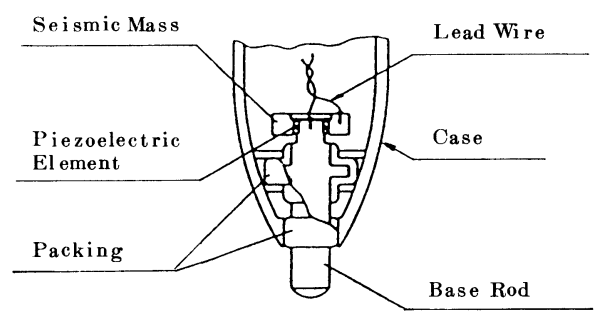

Fig. 1 Structure of pick-up
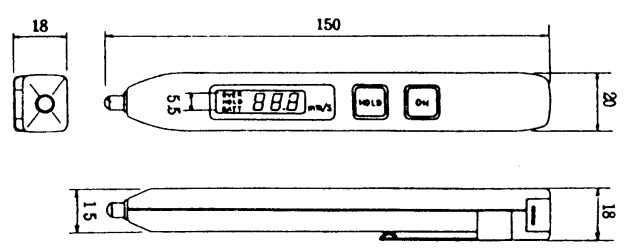

Fig. 2 Outlook of machine checker

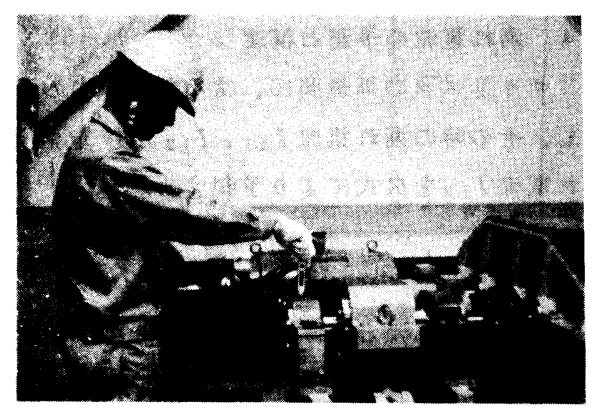

Fig. 3 Diagnostic scene of machine checker 
1. はじめに

サイリスタは、昭和 50 年代になって、劣化によるトラブルが発生しはじめ、生産設備への影響が增大してをて らる。乙のような状況にあって、現在実施している診断方法は、サイリスタを盤より取り外し、漏れ電流を测定

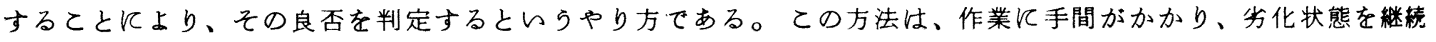
して監視することが難しいといら問題をかかえている。とれを解決すへくく今回、劣化状況を簡便かつ高精度に診 断でをるサイリスタ劣化診断装㯰を開発したので報告する。

\section{2. 漏れ流の测定原理}

本装置による漏れ電流の測定方法は、サイリスタを 制御盤から取り外すととなく、各部の漏れ電流を測定 する点に特徵がある。すなわち、サイリスタが回路に 組み込をれた状態で、その両極（アノード，カソード）間 飞、単相交流電圧を印加し、その時の漏孔電流をサーチコ イルにて検出するるのである。測定原理をFig.1亿示す。

なお、漏れ電流の測定部位は 3 ポイントあり、各々の漏 れ電流の值により、サイリスタ素子と保護回路 $(\mathrm{C}-\mathrm{R}$ スナバー回路）の劣化を同時に判定できる。

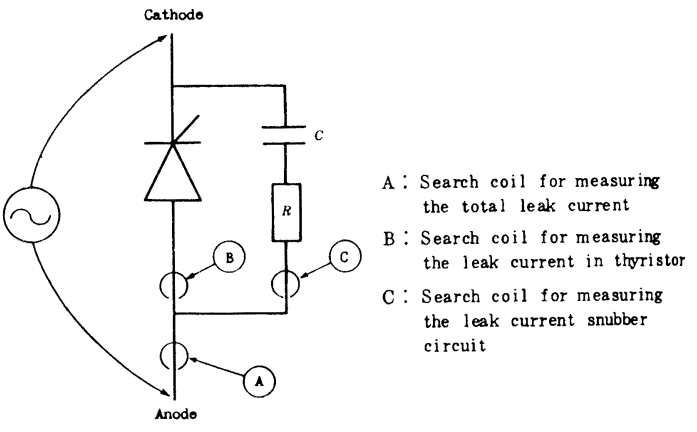

Fig. 1 Principle of leak current measurement

\section{3. 菱置の構成と特徵}

装置の構成は、サイリスタの両極間に単相交流電圧を印加するための電圧発生器やデータ解析用マイコンを内 蔵した本体、および、漏れ電流を測定するクランプ・メーターからなる。本体前面には、測定モードの選択、ス ナバー回路定数を設定するディジ・スイッチおよび診断結果を表示するランブなどが設置されている。本体は、 小形・軽量化により可搬型とし、診断内容の明細もプリントアゥトでをる。

次に、本装置の特徵を示す。

(1) サイリスタを制御盤から取り外すととなく、漏れ電流を測定でさるととから、診断作業時間が従来の方法 に比較し、1 $1 / 5 \sim 1 / 9$ 亿短縮でさる。

(2) 離結線が不要のため、診断後の誤結線による三次トラブルがなくなる。

(3) 劣化判定の自動化により、専門知識がなくても、簡便かつ高精度に猃断でるる

(4) 劣化程度が $0 \sim 5$ の 6 段階の劣化度として出力されるため、劣化傾向の管理が容易になる。

\section{4. 漏れ雪流の予测と精度}

サイリスタの両極間に、常用電王以内の単相交流電圧 $V_{1}, V_{2}$ を印加 し、その時の漏れ電流 $I_{\mathrm{L} 1}, I_{\mathrm{L} 2}$ から定格せん頭順逆耐電圧 $V_{\mathrm{X}}$ で漏 れ電流 $I_{\mathrm{Lx}}$ を次式により予測する。

$$
I_{\mathrm{LX}}=I_{\mathrm{L} 1}+\frac{I_{\mathrm{L} 2}-I_{\mathrm{L} 1}}{V_{2}-V_{1}} \times\left(V_{\mathrm{X}}-V_{1}\right)
$$

予測漏九電流と実際の漏れ電流との関係をFig. 2 亿示す。

なお、16 年間使用したサイリスタ（型式：CH03 CF-400A） 54 素子を 診断した結果、高い相関が得られ、診断時間も従来の $1 / 6$ 亿短樎された。

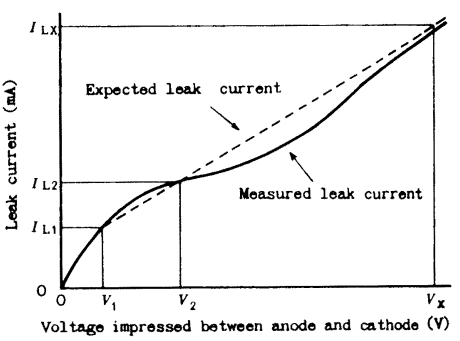

Fig. 2 Relation between vol tage impressed to thyristor and leak current 


\section{(345)}

橋梁部材のめっき時に発生する熱応力の検討

一溶融 Zn めっき橋梁のめっき中での応力挙動の研究(I)-

巴組鉄工所 ○家沢徹, 山下達雄, 金沢正午

新日本製鉄厚板条鋼研究センター一征矢勇夫

\section{1. 緒 言}

らわゆる液体金属脆化の一つである溶蛬 $\mathrm{Zn}$ 脆化は最近よく知られており，特に100万ボルト送電鉄

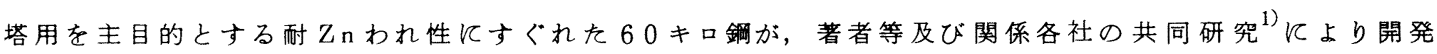
されて以来，各方面から注目されている課題である。一方，溶融严鉊めっき橋梁は次第に需要の伸びを 示しているが, 板桁, トラス弦材, ボックス桁等のめっき中での各種応力の検討は殆ど報告がなく, ま た鋼種す 40 キロから 60 キロ以上まであり，上記鉄塔の研究をそのまま適用でをない面がある。本研究 は各種橋梁部材のめっき中での応力挙動の研究（シリーズ $\mathrm{A} ）$ ，及びてれと連揳する高張力鋼開発（シ リーズ B ) を行らるので，東京大学奥村敏恵名誉数授の指導を受けている。本報告はシリーズAの(I)と して,めっき時の熱応力と浸漬速度の関係につんて報告する。

\section{2. 解析方法}

$\mathrm{Zn}$ めつ仕様の板桁, トラス弦材, ボックス桁, 橋脚の 4 構造部材につんて板要素で分割し，めっを漫漬過程を10 数段階の漫漬位置に分け，それぞれの時刻における要素温 度を熱伝導解析により与え熱応力の有限要素解析を行った。 この解析值は高温ゲージよる熱ひする実測值と比較的よ く一致するととを確認した。

\section{3. 結 果}

Fig. 1 Vnめっき時における熱応力の時間的変化を通 常の漫漬速度の中では比較的遅い $1.6 \mathrm{~m} / \mathrm{min}$ で板桁をめっ さする場合の例で示す。トラス弦材, ボックス析等す熱応 力変化は部位毎飞類似の挙動を示す。Z n 脆化に直接関係 するのはZnとぬれ後の引張応力であるが, 図のように部 材の中央及び上部で引張が発生するのはZnぬれ前であり， 通常の浸漬速度範囲では Zn 脆化関係する引張応力は発 生しないといら結果を得た。

しかし, Fig. 2 に各部材のウェブ中央部に発生する最大 圧樎応力と浸漬速度の関係を示すように, 板桁, ボックス 枌では浸漬速度が速い場合です2 $5 \mathrm{~kg} \mathrm{f} / \mathrm{mm}^{2}$ の压縮応力の発 生がある。板析などの比較的薄板構造で,めっき時にウェ ブに大をな㴼応力が作用すると面外変形が生じ，その二 次応力が既飞 Z n とぬ九状態の下方部位飞発生する可能性 が考えられる結果を得た。との三次応力そのるのについて は次回で報告する。

1）送電鉄塔用 $60 \mathrm{~kg} \mathrm{f} / \mathrm{mm}^{2}$ 高張力鋼開発委員会 J S S C, Vol. 21, No. 221,1985

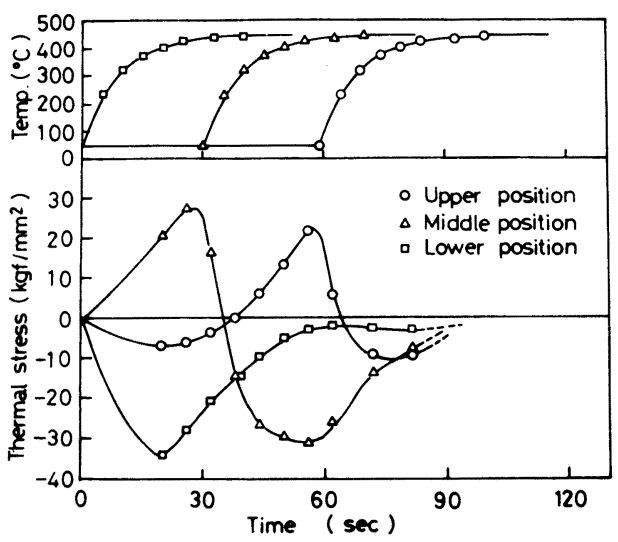

Fig. 1 Thermal stress and temperature variation in plate girder which was dipped into molten zinc.( Dipping speed : $1.6 \mathrm{~m} / \mathrm{min}$ )

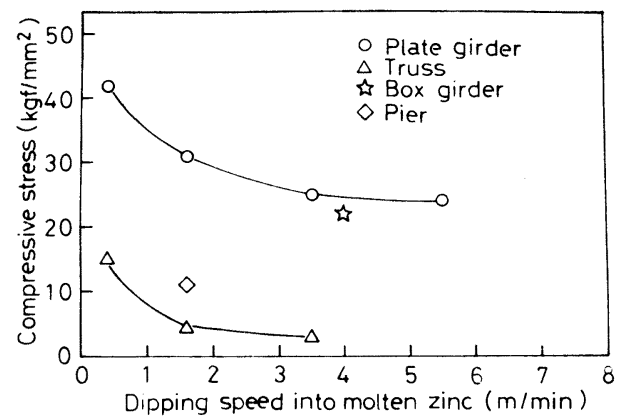

Fig. 2 Relation between dipping speed and maximum thermal compressive stress in web plate. 
新日本製鉄厚板条鋼研究センタ一征矢勇夫

1. 緒言

溶融 $\mathrm{Zn}$ 脆化の原因となる応力的要因として以下の二つが考えられる。一つは前報(I)で報告しためっ き中に発生する熱応力であり，もら一つ溶接によって生じた溶接残留応力である。この溶瀜 Zn 脆化 に及ほす溶接残留応力の影響に関しては，現在まではとんど報告がなくその応力挙動につんては明らか でない。本報告(II)，および次報の(四)は，乙の溶接残留応力の影響についての研究で，こてでは橋梁部材 に発生する代表的な溶接残留応カレヘルの実測結果，および全ての構造型式の橋梁部材に適用可能な有 限要素法を用いた溶接残留応力の解析方法について報告する。

2. 溶接残留応力の測定方法, および測定結果

Fig. 1 飞一例を示すよう飞実大の板桁試験体（SM 50 B，部材長；4,200) を 3 体製作し, 溶接部の止端部にひずみゲージを貼付し, 応力開放法にょり弾 性ひすみを測定し，溶接残留応力を求めた。

Table 1 亿その結果をまとめて示す。特にめっきわれが生じ易いまわし溶接 部におんては溶接線直交方向の応力が $43 \sim 45 \mathrm{~kg} \mathrm{f} / \mathrm{mm}^{2}$ とほ り，溶接残留応力と溶融 $\mathrm{Zn}$ 脆化との関連性は大をんと考える。

3. 溶接残留応力の解析方法, および解析結果

有限要素法により溶接残留応力を求める方法として, 冷却過程での温度分布 を入力し弾塑性解析を行う方法が一般的であるが, 実大規模の橋梁部材に適用 するのは困難である。本研究においてはFig. 2 に一例を示すよらに解析位置に 負の温度分布を与え, その温度差によって生ずる引張熱応力を有限要素法を用 らて弾性解析し，溶接残留応力と読み代える経済的な方法を考案した。

Fig.1亿示すような溶接部位を解析した結果を実測值と対比してTable 1 K

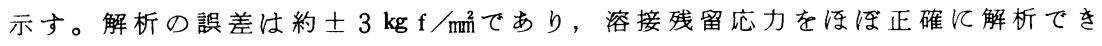
るととを確認した。

\section{4. をとめ}

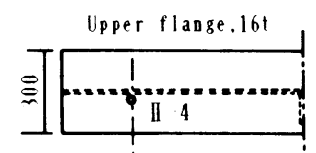

橋梁部材の溶接残留応力レベルの把握，およびその簡便な計算方法を確立す るととができ，溶虽 $\mathrm{Zn}$ 脆化対策を講ずる際の有効な情報を得ることがでをた。

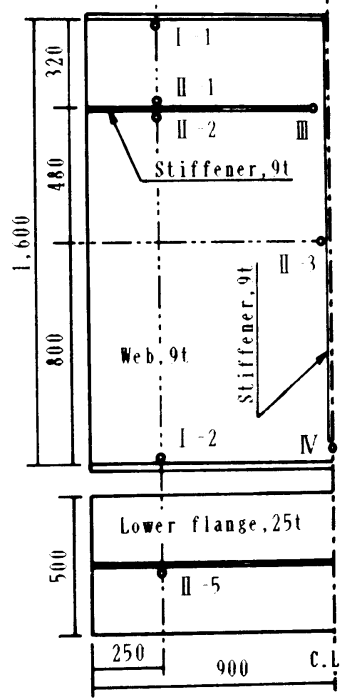

Fig.l Measured and analyzed location (unit:me)

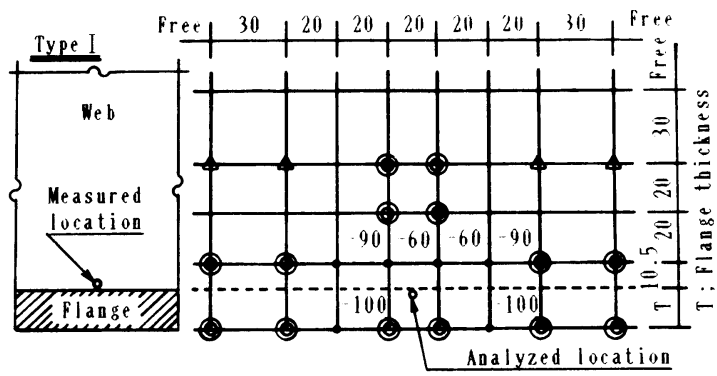

(C) : $-250^{\circ} \mathrm{C}, \triangle ;+25^{\circ} \mathrm{C}$, No mark $: 0^{\circ} \mathrm{C}$

Fig. 2 Example of temperature distribution in analyzed area (unit;mm)
Table 1 Comparison of calculated value with measured value of welding residual stress in plate girder

\begin{tabular}{|c|c|c|c|c|c|c|c|}
\hline \multirow{3}{*}{\multicolumn{2}{|c|}{ Location }} & \multicolumn{6}{|c|}{ Welding residual stress } \\
\hline & & \multicolumn{3}{|c|}{ Transverse direction } & \multicolumn{3}{|c|}{ Longitudinal direction } \\
\hline & & $\begin{array}{l}\text { Measa- } \\
\text { rement }\end{array}$ & $\begin{array}{l}\text { Calcu- } \\
\text { lation }\end{array}$ & $\begin{array}{l}\text { Diffe } \\
\text { rence }\end{array}$ & $\begin{array}{l}\text { Measu- } \\
\text { rement }\end{array}$ & $\begin{array}{l}\text { Calcu } \\
\text { lation }\end{array}$ & $\begin{array}{l}\text { Diffe- } \\
\text { reace }\end{array}$ \\
\hline \multirow{2}{*}{$\begin{array}{l}\text { Pil- } \\
\text { let } \\
\text { weld }\end{array}$} & I & 6.9 & 6.7 & -0.2 & 32.5 & 32.9 & +0.4 \\
\hline & II & 5.8 & 5.8 & \pm 0 & 35.0 & 38.1 & +3.1 \\
\hline \multirow{2}{*}{$\begin{array}{l}\text { Box- } \\
\text { ing } \\
\text { ve Id }\end{array}$} & III & 43.8 & 42.2 & -1.6 & 15.4 & 18.0 & +2.6 \\
\hline & $\mathbf{I V}$ & 44.7 & 42.5 & -2.2 & 18.9 & 20.9 & +2.0 \\
\hline
\end{tabular}


' $87-$ S 1083

溶接残留応力のめっき中での経時変化

一溶虽 $\mathrm{Zn}$ めっ橋梁のめっきでの応力挙動の研究(III)-
巴組鉄工所
○山下達雄, 家沢
徹, 金沢正午
新日本製鉄厚板条鋼研究センター 征矢勇夫

1. 緒言

前報(II)て橋梁部材飞発生する溶接残留応カレベルの実測, およびその有限要素解析方法につとて報告 した。次にその溶接残留応力がめっを浸清中いかなる举動をするかが重要な問題であり,さらに最終的 にはめっき浸漬中ての応力挙動を熱応力と残留応力との組合せである総合応力として把握するととが， 溶虽 $\mathrm{Zn}$ 脆化防止のために必要となる。本報告(III)ではっき漫漬中の溶接残留応力の経時変化化関する 実験結果について報告し, 総合応力については次回に報告する予定てある。

2. 実験方法

試験片はFig.1亿示すような裹拘束ピードのパス数によって溶 接残留応力が变化可能な $\mathrm{T}$ 字形小型試験片を用的た。所定の溶接 残留応力を持つ試験片を $450 \mathrm{C}$ の溶融 $\mathrm{Zn}$ 中, および比較のため 450 Cの加熱师中飞保持し, その後空冷, または水冷する。溶接 残留応力の測定は処理後の試験片にひずみゲーシを貼り, 応力開 放法に上る弾性ひずみの測定值から求めた。

\section{3. 実験結果}

Fig. 2 K $18.7 \mathrm{~kg} \mathrm{f} / \mathrm{mm}^{2}$ の初期残留応力を持つ試験片を 450 Cに保持した場合の残留応力の変化を示す。炉加熱，およ びめっき後空冷した場合, 残留応力は保持時間によってほ とんと変化せず, めっき後水泠した場合約 $6 \mathrm{~kg} / / \mathrm{mm}^{2}$ 低下す る。空冷した場合残留応力が変化しないのは 450 Cでは応 力除去が生じないてとを示し, 水冷した場合の低下は水冷 中に発生する熱応力によって表面に引張塑性ひずみが生ず るためと考える。

Fig. 3 K $50.0 \mathrm{~kg} \mathrm{f} / \mathrm{mm}^{2}$ と大を初期残留応力を持つ試験片 を $450 \mathrm{C}$ 亿保持した場合の残留応力の変化を示す。炉加熱, およびめっを後架冷した場合残留応力は保持時間ととるに 急敨飞約 $30 \mathrm{~kg} \mathrm{f} / \mathrm{mm}^{2}$ K低下し, その後徐々飞低下する。水 冷した場合は空冷の場合上り約 $8 \mathrm{~kg} f / \mathrm{mm}^{2}$ 低下する。残留応

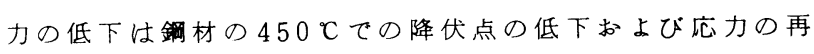
配分飞ょるものと考元る。

4. をぬ

溶融 $\mathrm{Zn}$ 浸清中の溶接残留広力は初期残留広力が 450 C ての鋼材の降伏点以下の場合はそのま〉保持され, 初期残 留応力が 450 Cでの降伏点以上の場合は保有ひずみに対応 する 450 Cで応力ーひすみ曲線上の応カレヘルまで低下

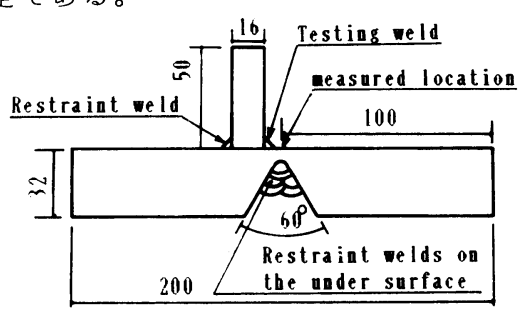

fig. 1 Shape of test specinen (Material: SM50B, unit;m)

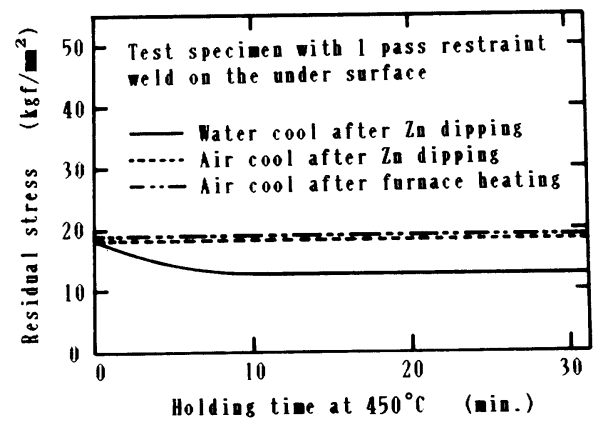

Pig. 2 Decrease of welding residual stress by $Z$ a hot galvanizing or furnace beating at $450^{\circ} \mathrm{C}$

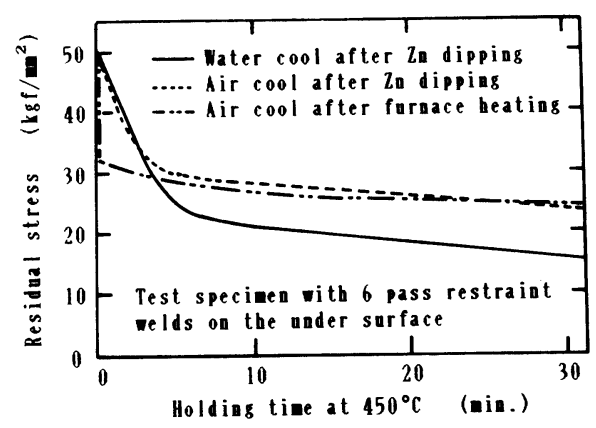

Fig. 3 Decrease of welding residual stress by $Z n$ hot galvanizing or furnace heating at $450^{\circ} \mathrm{C}$ するものと考えられる。したがって, 鋼種に関わらず初期溶接残留応カレヘルと450てての応カーひず み曲線を求めれば, めっき漫漬中の応力変化を推定できると考える。 
(348) 橋梁用鋼材の耐溶融 $\mathrm{Zn}$ めっきわれ性評価試験方法の検討 一溶融 Znめっき橋梁用高張力鎆材の研究 ( I ) -

新日本製鐵侏 厚板条鋼研究センター 金谷研, 井上尚志, 山戸一成 巴組鉄工所

○家沢徹, 山下達雄, 金沢正午

\section{1. 粕言}

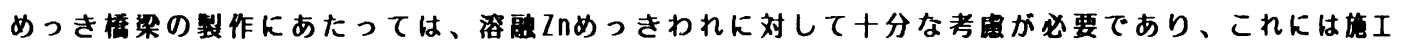

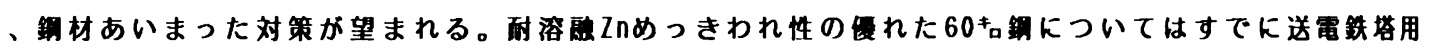

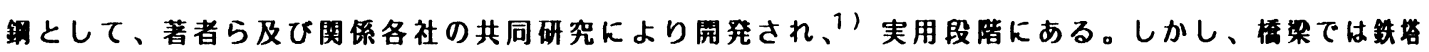

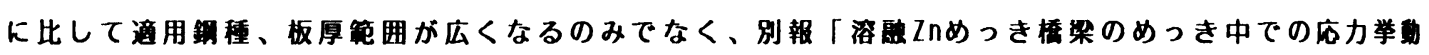

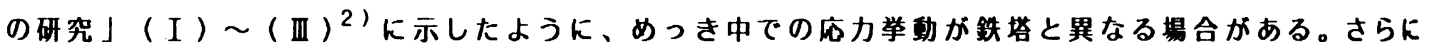
、めっき時の面外変形による 2 次店力の発生なども考虑する必要がある。

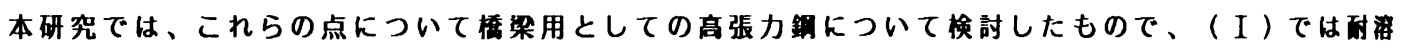
融Znめつきわれ性評価試晚法について検討し、それを用いてわれ発生限界を明らかにした桔果を述べる 2. 評俩試畧法の検討

拘束バス数を変えることによって任意に残留応力を変更できる小型再現試醛方法として、別報「沿接

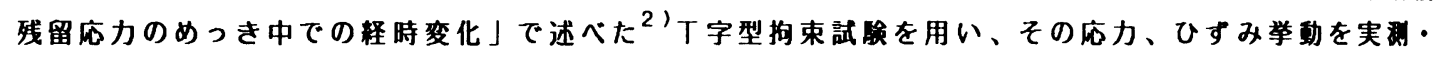
解析した。また、Znめつき時の応力変化についても調查した。

その䊅果、このような小型の試臨で浴融Znめっきわれを再現でき、また拘束バス数も少なくて大きな 応力が得られることが分った。

3.われ発生眼界の蚞討

一般に用いられているSM50,53,50Y 及ひSH58Q( $\mathrm{t}=25 \sim 40 \mathrm{~mm})$ のを供試城とした。それらの化学成分

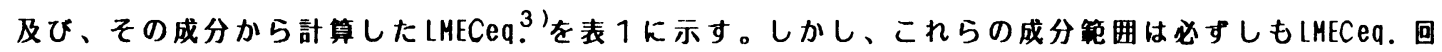

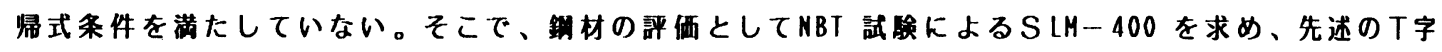
型拘束試検でのわれ発生バス数と、その時の残留応力の関係をFig. 1 に示す。その桔果、両者には良い 相関が認められ、残留店力 $25 \mathrm{kgf} / \mathrm{mm}^{2}$ 以上でわれ発生の可能性があり、まわし澄接部のように残留店力 の高いところでは40x 以上のSLM-400 が望まれることが分った。

Table 1 Chemical composition

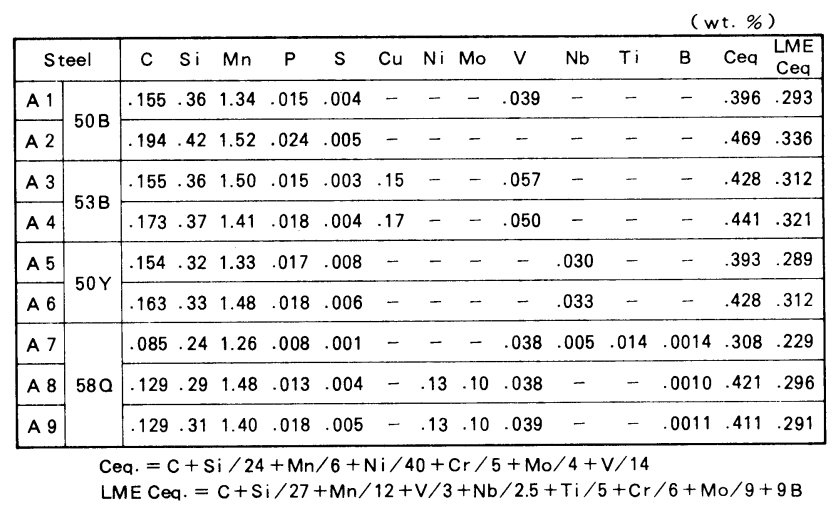

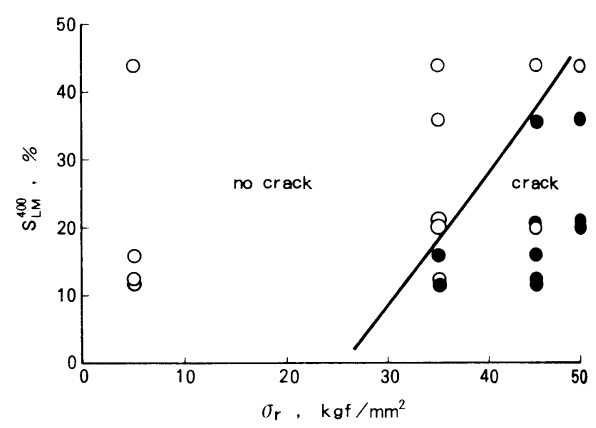

Fig. 1 The cracking area by $T$-type weld restraint test represented by its residual stress and $\mathrm{S}_{\mathrm{LM}}^{400}$ at HAZ by NBT test

1) 送電鉄塔用 $60 \mathrm{~kg} / \mathrm{mm}^{2}$ 高張力婤開発委貝会 JSSC.Vol. 21, No. 221, 1985

2) 山下ら、: 第 114 回請演大会発表予定

3) 武田 5、: 铁と铞, Vol.70, No.6(1984), P124 
'87-S 1085

(349) 耐溶融 $\mathrm{Zn}$ めっわれ性に優れた橋梁用 $50 \mathrm{kgf} / \mathrm{mm}^{2}$ 鋼の開発

一溶融 Znめっき橋梁用高張力鋼材の研究 (II) 一

新日本製鐵侏 厚板条鋼研究センター ○金谷 研, 井上尚志, 山戸一成

\section{1、楮言}

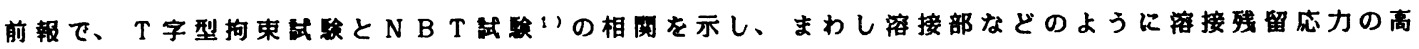
いところでは40\%以上のSLM-400が咅まれることを示した。

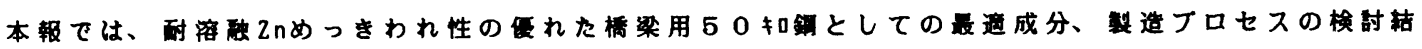
果について辄告する。

2、実唤方法

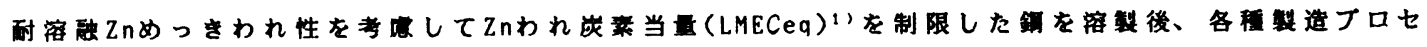

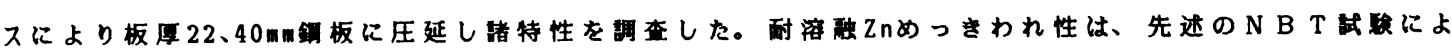

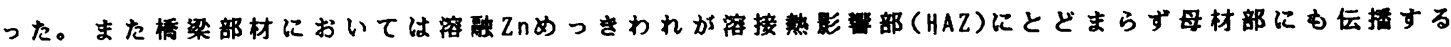
靚合があるため、母材についても同じ方法で調查した。

\section{3、実験結果}

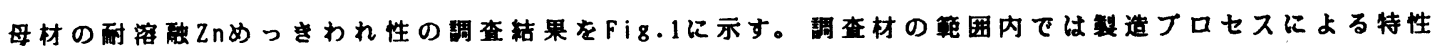
值の变化は小さく、いずれも感受性は低い(SLM-400が商い)。この轱果はHAZでの発生防止か直要である ことを示睃しているものと考える。またTMCP の通用はLMEceqを高めずに高強度が得られ有效であ

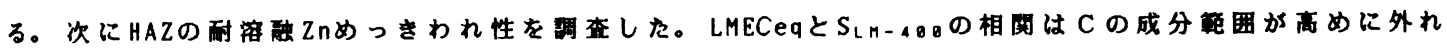

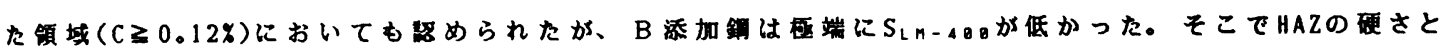

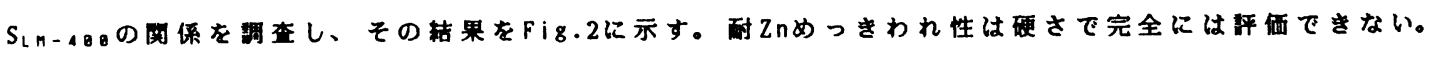
特に同じ硬さですB添加邻はわれ感受性が高 い。これはBが䢂界の焼入性を高めるためと 考えられる。これらの䠜果からTable 1 の上段 に示すような成分系か通切と考えられ、それ をTMCPで紫造した场合に同表下段に采すよう な特性か想定される。

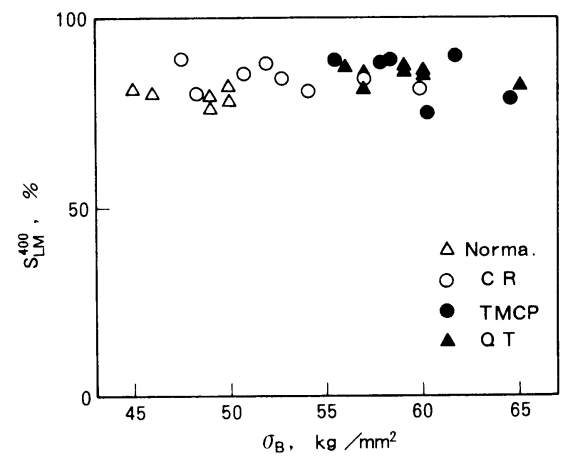

Fig. 1 The effect of production process on $S_{L M}^{400}$ of $B M$ and $\sigma_{B}$

1)武田ら、铁と勿, Vol.70,No.6(1984),p124

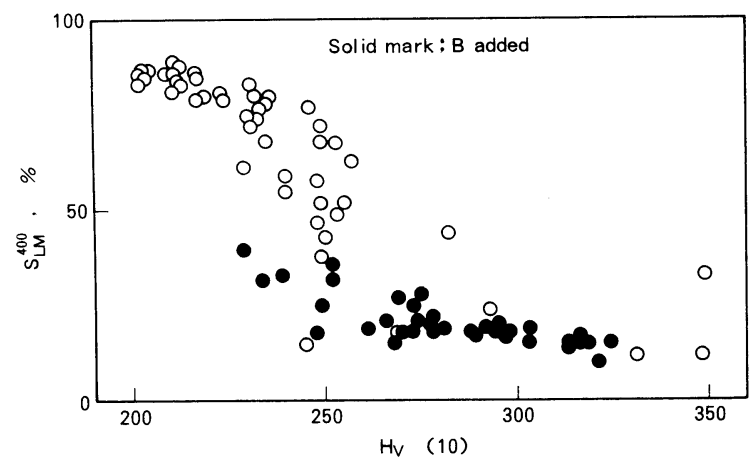

Fig. 2 The relationship between $\mathrm{S}_{L M}^{400}$ and hardness of synthetic HAZ .

Table 1 Example of resistance steels to zinc coating induced cracking for bridge.

\begin{tabular}{|c|c|c|c|c|c|c|c|c|}
\hline Steel & $t$ & C & \multicolumn{2}{|l|}{$\mathrm{Si}$} & $\mathrm{Mn}$ & $\mathrm{Nb}$ & $\mathrm{T} \mathrm{i}$ & LMEceq \\
\hline HT50 (A) & $40 \mathrm{~mm}$ & 15 & \multicolumn{2}{|c|}{.20} & 1.15 & 01 & .01 & 25 \\
\hline HT 50 (B) & $40 \mathrm{~mm}$ & 08 & \multicolumn{2}{|c|}{20} & 1.45 & .02 & .01 & 23 \\
\hline \multirow{2}{*}{ Steel } & \multicolumn{4}{|c|}{ Mechanical properties } & \multicolumn{2}{|c|}{ NBT $\left[\begin{array}{ll}B & M\end{array}\right]$} & \multicolumn{2}{|c|}{$N B T[H A Z]$} \\
\hline & $\begin{array}{c}\mathrm{TS} \\
\mathrm{kg} / \mathrm{mm}^{2}\end{array}$ & $\begin{array}{r}V P \\
\mathrm{~kg} / \mathrm{m}\end{array}$ & & $\begin{array}{l}{ }_{0}{ }^{\mathrm{C}} \mathrm{Trs} \\
\end{array}$ & $\begin{array}{l}\sigma+400 \\
\mathrm{~kg} / \mathrm{mm}^{2}\end{array}$ & SLM 400 & $\begin{array}{l}\sigma f 400 \\
\mathrm{~kg} / \mathrm{mm}^{2}\end{array}$ & $\begin{array}{c}\text { SLM400 } \\
\%\end{array}$ \\
\hline HT50 (A) & 55 & 45 & & -90 & 60 & 85 & 70 & 75 \\
\hline HT50 (B) & 55 & 50 & & -90 & 65 & 90 & 75 & 85 \\
\hline
\end{tabular}


（350）变状圧縮板の修復法に関する研究

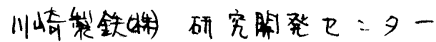

11)开豊

○芝本正富

\section{1. 粕言}

船舶の衡突、暴風による車止めへの街突などの突発的過大荷重、あるいは長期の苛酷な使用による老

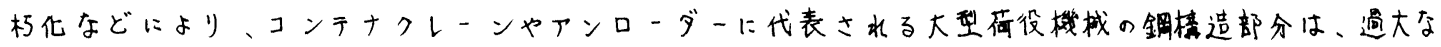
面外変形を被る色险性が高く、实除にも数多くの椇賃例があるようである。

本研究は、これら有害とみなされた面外变形を現場で短正するとともに、補强を行なた場合の修推 効果を、压縮パネルの座屈試験により調查したものである。

\section{乙、試賖}

試駼体は板厚 $8 \mathrm{~mm}$ ，全幅 $780 \mathrm{~mm}$ ，長士1500 mmas54/製銅板5枚を用いた。予め、武

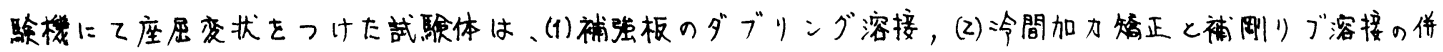

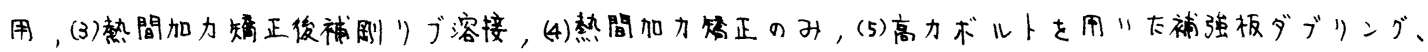

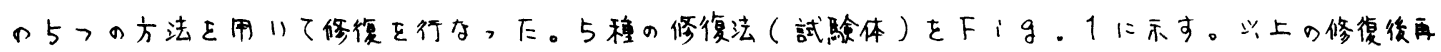

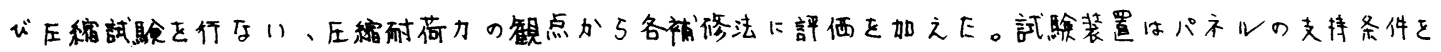
明確にするたの、できるだけ4迅单純支持条件に近くなる样に、侧迅の回転およで維啧方向の面外変位

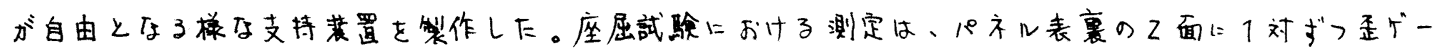
ジを設置し、各部の心力分布を荷重ステップ5七。の每に計测㫃録するとともに、パ齐ルの面外变形を 变位計を用いて計剖記録しE。

了、まとめ

5福の修復法は、川ずれも侓全な圧縮板の強度と同等以上の強度回復が可能であるが、实施エにあた つてはいくつかの留意点がある。(1)面外变形を知正世ず变状部のみを覆うように補強板をす山两溶接に てダブリンゔして修復する場合、補强効果を高める為には、变状部区含み健全部のある程度広い籍团に

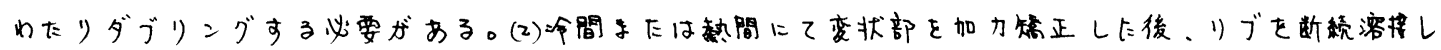

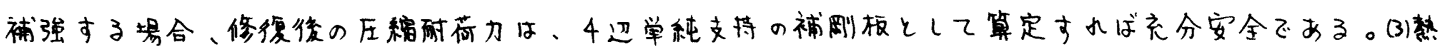
間にて加力稪正する場合、最大面外変形量が充分小士く㮩正でれば、健全パネ几と同程度の而力を磷

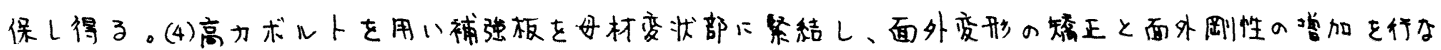
えば、检めて高い強度上并が期待でさる。但し、補強板は健全部にて伸ばしておく必要ガある。

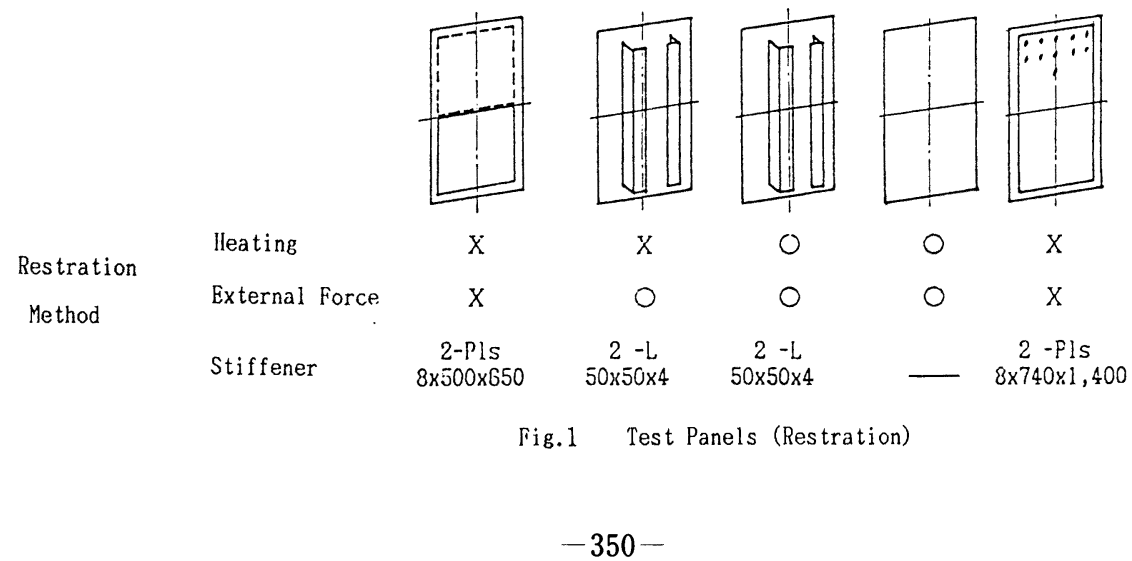

